\title{
WestVirginiaUniversity
}

THE RESEARCH REPOSITORY @ WVU

West Virginia Agricultural and Forestry Experiment

Davis College of Agriculture, Natural Resources

Station Bulletins

And Design

$1-1-1918$

\section{Infection and Immunity in Apple Rust}

N.J. Giddings

Follow this and additional works at: https://researchrepository.wvu.edu/ wv_agricultural_and_forestry_experiment_station_bulletins

\section{Digital Commons Citation}

Giddings, N. J., "Infection and Immunity in Apple Rust" (1918). West Virginia Agricultural and Forestry Experiment Station Bulletins. 170.

https://researchrepository.wvu.edu/wv_agricultural_and_forestry_experiment_station_bulletins/170

This Bulletin is brought to you for free and open access by the Davis College of Agriculture, Natural Resources And Design at The Research Repository @ WVU. It has been accepted for inclusion in West Virginia Agricultural and Forestry Experiment Station Bulletins by an authorized administrator of The Research Repository@WVU. For more information, please contact ian.harmon@mail.wvu.edu. 
West Virginia University Libraries

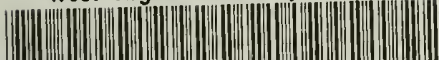

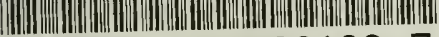
308021007621097 



\section{Tratest Virginia faniurersity Aqricultural Experiment Station}

MORGANTOWN

DEPARTMENT OF PLANT PATHOLOGY

\section{Infection and Immunity in Apple Rust}

TECHNICAL BULLETIN

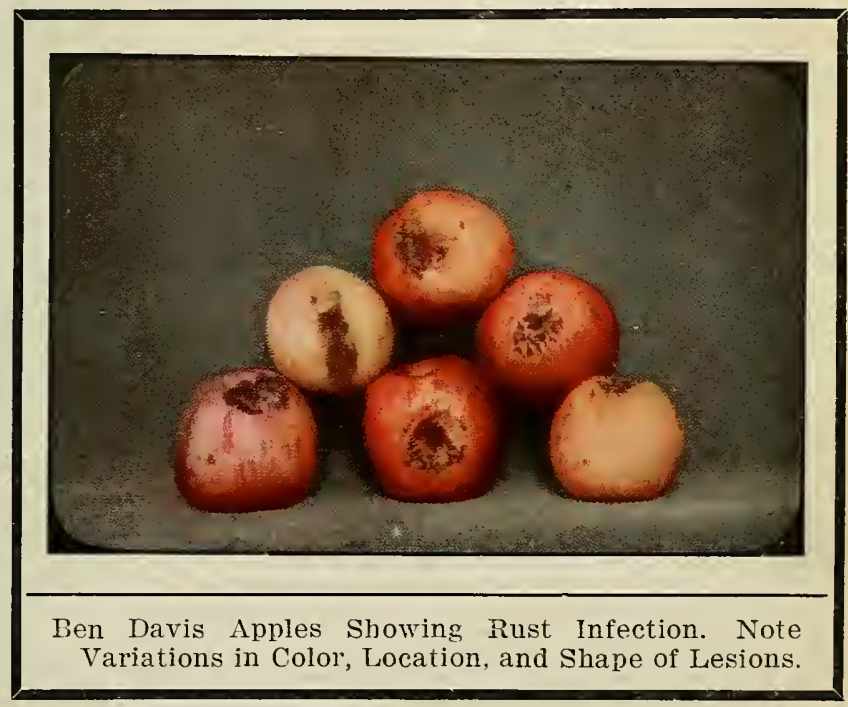

BY

N. J. GIDDINGS

Bulletins ard Reports of this Station will be Mailed Free to any Citizen of West Virginia upon Written Application. Address Director of the West Virginia Agricultural Experiment Station, Morgantown, W. Va. 


\title{
THE STATE OF WEST VIRGINIA
}

\author{
Educational Institutions
}

\section{THE STATE BOARD OF CONTROL}

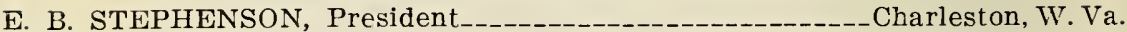
JAMES S. LAKIN

Charleston, W. Va.

J. M. WILLIAMSON

Charleston, W.Va.

The State Board of Control has the direction of the financial and business affairs of the state educational institutions.

\section{THE STATE BOARD OF REGENTS}

M. P. SHAWKEY, President____State Superintendent of Schools

GEORGE S. LAIDLEY

Charleston, W. Va.

NOAH G. KEIM

Elkins, W.Va.

EARL W. OGLEBAY

Wheeling, W. Va.

FRANK N. SYCAFOOSE._._.

The State Board of Regents has charge of all matters of a purely scholastic nature concerning the state educational institutions.

\section{WEST VIRGINIA UNIVERSITY}

FRANK BUTLER TROTTER, LL.D. President

\section{Agricultural Experiment Station Staff}

JOHEN LEE COULTER, A.M., Ph. D. - BERT H. HITE, M.S. - A.M., Ph. D. FRANK B. KUINST, A.B. - Chemist **CHARLES E. WEAKLEY Jr. J. H. BERGHTIUS-KRAK, B.SC. -_. W. E. RUMSEY, B.S. Agr. -.. N. J. GIDDINGS, Ph.D._._... A'NTHONY BERG, B. S. †L. I. KNIGHT, Ph.D. HORACE ATWOOD, M.S. Agr. E. L. ANDREWS, B.S. Agr. F. W. STEMPLE, M.S. T. C. MeILVAINE, M.S. Agr. ROBERT M. SALTER, M.Sc. - **C. F. WELISS, A.B. W. H. AILDERM AN, B.IS. Agr.

L. F. ISUTTON, B.S., B.S. Agr. H. L. CRANE, B.S. Agr. Asstant Horticulturist ** ROLAND H. PATCH, M.S. H. W. RICHEY, B.S. Agr. L. M. PEAIRS, M.S. **E. W. SHEETS, B.S. Agr., M.IS... J. J. YOKE, B.S. Agr. R. H. TUCKWILLER, B.S. Agr. C. A. LUEDER, D.V.M. *A. J. DADISMAN, M.S. Agr. - **C. F. SARLE, B.S. C. E. STOCKDALE, B.S. Agr. D. M. WILLIS, LL.M. -

In co-operation with the University of Chicago.

* In co-operation with the U. S. Department of Agriculture.

* Leave of absence. 


\section{SUMMARY AND CONCLUSIONS}

York Imperial apple leaves are usually susceptible to rust for from fifteen to twenty-five days after they unroll from the bud.

The length of this period of susceptibility seems to be closely associated with growth conditions.

The associated chemical changes are worthy of further study.

Infection data based on periods of rainfall, gelatinization of sori, or discharge of sporidia mean but little unless definite proof is at hand to show that infection did actually take place, since abundant sporidia discharge has been observed without resultant infection.

Sporidia are not discharged in appreciable numbers at a temperature below $50^{\circ} \mathrm{F} .\left(10^{\circ} \mathrm{C}\right)$.

Under optimum conditions there may be fairly abundant sporidia discharge in less than three hours after first moistening a mature sorus.

Slight evaporation apparently favors sporidia discharge.

The greatest injury to apple trees is evidently due to foliage infection. A severe rust infection results in deformed fruit, a general reduction in size of fruit, and great loss of vigor on the part of the trce. There is a very distinct relationship between the number of rust spots on a York Imperial apple leaf and the length of time the leaf is retained by the tree.

The effect of a severe rust infection may apparently persist for more than one season.

A large percentage of the fruit may show rust if the infection occurs at about the time the blossoms fall.

There is a marked variation in the susceptibility of red cedar trees to this disease.

Apple rust may be controlled by the use of sprays, but this method is entirely impractical in commercial orchards.

Destruction of cedars around susceptible orchards is effective as a control measure, but the cedar-free area should be at least two miles around the orchard if consistently good results are to be secured. The cost of clearing land of red cedars has not been found excessive under West Virginia conditions. 


\section{CONTENTS}

Summary and Conclusions

Introduction -

Historical Summary -_-_-_-_-_-_-_...- 5

Economic Importance -...-_-_-_-_-_-_-_-_- 8

Life History of Fungus

Methods of Studying Field Infections

Factors which Influence Infection of Apple------ 12

Immunity in Apple Leaves.-.-_-_-_-_-_-.---- 31

Physiological Effect of Rust on Apple

Infection and Immunity of the Red Cedar.-.-_--- 50

Control of Apple Rust._...- 51

Use of Sprays

Field Experiments in 1912

Field Experiments in 1913_.....-_..-. 55

Field Experiments in 1914_-_._-_._- 58

Destruction of Red Cedars

Destruction or Prevention of Rust Galls 68

Literature Cited -..-_-_-_-_-_-_-_-_-_-_-_---- 70 


\title{
Infection and Immunity in Apple Rust
}

\author{
By N. J. Giddings*
}

The common rust of apple caused by Gymnosporangium juniperivirginianae is a disease which has received attention at the hands of several investigators during recent years. Its economic importance, its peculiar and incompletely known life history, together with the abundance of available material, have led to the study of various aspects of the disease in different institutions.

The severity of this disease in West Virginia during the season of 1910 was such that it seemed imperative to undertake experiments on ways and means for its prevention. Ordinary methods were found very ineffective in controlling this rust, and the work quickly led into more fundamental side channels.

A careful search through the literature of the disease showed that there were many blank spaces in the life history of the fungus and that there was a diversity of opinion on certain important points. No very complete records were found as to the exact nature of the injuries on either apple or cedar; there were only very general and indefinite statements as to the various conditions influencing infection and practically no evidence as to why the rust was more severe during certain seasons, on particular varieties, or in its attack on certain trees.

Investigations were finally undertaken with the aim of securing definite and reliable information along some of these lines, and it is believed that the results attained will add somewhat to our knowledge of this disease and the factors which in some combinations give infection of the apple or the cedar while in others no infection, or even apparent immunity.

Bulletin 154 from the West Virginia Agricultura! Experiment Station discusses the experimental work conducted previous to 1915 , but owing to the fact that this publication was soon out of print it has seemed wise to include here some of the more important facts mentioned in it.

\section{HISTORICAL SUMMARY}

Gymnosporangium juniperi-virginianae was discovered and named by Schweinitz in 1822. Schweinitz in 1832 also seems to have been the first to mention the aecial stage, which he designated as Caeoma (Aecidium) pyratum. The genetic connection between the telial and aecial forms was finally worked out by Thaxter in 1886 , and Heald (190\%, p. 219) called attention to the biennial character of the fungus on the red cedar.

- The author is indebted to Anthony Berg for valuable assistance in connection with both field and laboratory work. 
Coons (1912, p. 217) conducted some detailed studies on the development and discharge of sporidia and was the first to call attention to their forcible discharge. He says, "The process of putting out germ tubes requires from six to fifteen hours." Fulton (1913, p. 6:2) reported some investigations as to the factors which influence sporidia production and states that, "From the first swelling of the gelatinous horns to the formation of infection spores about twenty-four hours of moisture are required." Reed and Crabill (1915, p. 28) found that, "A teleutospore must be kept covered with a good film of water or suspended in water for at least four hours at optimum temperatures" in order to secure germination. Giddings and Berg (1915) stuclied the factors inducing sporidia discharge, noted the forcible ejection of sporidia, and secured abundant sporidia discharge in less than three hours after first moistening galls. Weimer (1917) studied sporidia development and discharge and states that the telial horns must be kept moist for from four to five hours.

Reed, Cooley, and Rogers $(1912$, a) found that transpiration and carbon dioxide assimilation were greatly retarded in rust infected apple leaves; and Reed and Crabill (1915, p. 180) report that respiration is increased in such leaves.

Halstead (1889, p. 380) had the question of immunity in mind when he wrote, "Very likely some varieties of cultivated apple are more susceptible to the rust than others, but as the observations upon this point are very meagre and fragmentary it is not safe to draw general conclusions from them." The same question was brought to the attention of Stewart and Carver (1896, p. 538) when they carried on a series of experiments to ascertain why the cultivated apple in central Iowa should be free from Roestelia. 'They made inoculations with $G$. juniperi-virginianae upon the wild crab, Pyrus coronaria, and upon cultivated varieties at Ames, Iowa, and I.ong Island N. Y. Abundant Roestelia developed on the wild crab but in no case was it formed on the cultivated varieties inoculated at Ames. The experiment at Long Island gave evidence that some varieties were wholly exempt from Roestelia, which indicated that its absence on cultivated apples in Iowa might not be entirely due to unfavorable weather conditions, but chiefly to the fact that the varieties grown in Iowa were not susceptible. Fulton (1913, p. 62) published the results of some inoculation experiments which showed the development of immunity in apple leaves of susceptible varieties, and the same fact is mentioned by Reed, Cooley, and Crabill (1914).

Jones, (1893, p. 133) was the first to give any concrete evidence as to the value of cutting red cedars in order to eradicate the disease. He states that, "In the fall and winter of 1891-92 the red cedars were all destroyed in this orchard, and for a radius of one mile around a careful examination was made and every cedar found was uprooted. The result was magical. In former years many of the apple trees were entirely defoliated by rust in August; the past summer not a 
rusted leaf was found in the entire orchard. The moral is plain. Red cedars should not be allowed to grow in or near an apple orchard. From the scientific standpoint the result is interesting as indicating that the mycelium of this fungus is not perennial in the apple, and that the occurrence of the rust on the apples is dependent upon annual reinfection from the red cedar." It should be noted, however, that the red cedar is not reported as a common tree in Vermont. While the trees were all destroyed within a range of one mile of this orchard, it is quite likely that very few of them could have been found within a radius of two miles. Giddings $(1913,1.23)$ recommended a cedar-free area of at least one mile around orchards, and Reed, Cooley, and Crabill (1914) suggested cutting the cedars for one-half mile from orchards. Spraying of cedar trees was recommended by Heald (1907, p. 209) as practicable in certain cases.

Numerous apple spraying experiments are reported upon in the jiterature and the results were quite variable, as will be noted from the following statements: Galloway (1889, p. 413) gives data on spraying experiments for apple rust control at Vineland, N. J. He states that the foliage remained fairly healthy, yet the benefit was not sufficient return for the labor expended. Jones (1891, p. 139) conducted an experiment near Burlington, Vermont, in 1889. The trees were sprayed with ammoniacal copper carbonate May 17 th and May 30 th. The results showed no marked difference in the percent of t usted leaves, but the number of rust spots per rusted leaf was less on the sprayed than on the unsprayed trees. Pammel (1891. p. 43) sprayed trees of the wild crab apple with Bordeaux mixture and ammoniacal copper carbonate. He concluded that there was little benefit from spraying. Jones (1.892, p. 133) reported on further experiments in the control of apple rust by spraying. He secured fairly good results, but did not feel that this method of control was very practical. Austin (1901, p. 296) carried out the following spray program: Trees were carefully sprayed March 24th before growth started, again April 25th, May 4th, May 22nd, June 5th, June 20th, July 23rd, August 9th and August 28th. On October 10th the trees were examined and it was found that they were at least as badly infected as in the previous year. Emerson (1905)* reports the results of a detailed spray program. Twenty-two trees of the variety Wealthy, and eight of the variety Jonathan received from one to three applications of Bordeaux. The dates of spraving were April 26th, April 27 th, May 7th, May 9th, May 23rd, and May 28th. Trees which were sprayed on Mav 7th or May 9th showed remarkable control.

Hein (1908) says, "Although spraying with Bordeaux mixture or other fungicides is sometimes recommended as a treatment for rust, we have experimented for three years without any markedly bene-

\footnotetext{
- These statements in regard to Prof. Emerson are based on Pammel's report in Nebraska Agr. Exp. Sta. Bul. 84, The Cedar Apple Fungi and Apple Rust of Iowa, page 34.
} 
ficial results." Stewart (1910, p. 194) reports that Mr. F. A. Sirrine at Long Island has usually had little success in controlling rust in his bearing orchard by several applications of Bordeaux. However, in 1909 , trees given two applications of 3-3-50 Bordeaux showed only one-tenth as much rust as the unsprayed trees. Giddings (1911, p. 3) reports a case in which rust was well controlled by a single spray application. Reed, Cooley and Rogers $(1912$, p. 7) state that various spray materials are being tried for control of rust, but that no entirely satisfactory spray has been found up to the present time. Bartholomew (1912, p. 253) reports the results of experiments for the control of this rust by spraying. Applications of Bordeaux mixtures were made on May 15th, May 22nd and May 30th. He states that the spraying was done "immediately following the formation on the cedar galls of the jelly-like telial extrusions," and "before sufficient time had elapsed for the transfer of the sporidia from the galls to the apple foliage." The trees so sprayed showed pronounced decrease in the percent of infected leaves. He concluded that, "The proper time for spraying cannot be designated by any fixed dates, for the crucial time for action depends entirely upon such weather conditions as favor the development of the cedar galls." Giddings and Neal (1912, p. 258) found it possible to control this rust by spraying with lime-sulphur, Bordeaux mixture, or atomic sulphur. Reed, Cooley, and Crabill (1914) found a copper-lime-sulphur spray to be especially effective.

\section{ECONOMIC IMPORTANCE}

The common rust of apple is quite widely distributed through the central and eastern portions of the United States and has been found in Ontario, Canada. Rust on apple species has been reported for the following:

$\begin{array}{ll}\text { Alabama } & \text { Louisiana } \\ \text { Alaska } & \text { Maine } \\ \text { Arkansas } & \text { Maryland } \\ \text { Colorado } & \text { Massachusetts } \\ \text { Delaware } & \text { Michigan } \\ \text { D. of Colůmbia } & \text { Minnesota } \\ \text { Florida } & \text { Mississippi } \\ \text { Georgia } & \text { Missouri } \\ \text { Ilìnois } & \text { Nebraska } \\ \text { Indiana } & \text { New Jersey } \\ \text { Iowa } & \text { New York } \\ \text { Kansas } & \text { North Carolina }\end{array}$

Ohio

Oklahoma

Oregon

Pennsylvania

Rhode Island

South Carolina

South Dakota

Tennessee

Vermont

Virginia

West Virginia

Wisconsin

Kentucky

This disease was quite severe throughout the eastern section of West Virginia in 1910 , and in 1912 it was so destructive that the crop of York Imperial apples was an entire failure in nearly all orchards. The trees were well loaded with fruit, but it was of such inferior quality that it hardly paid for the cost of picking. Actual fruit losses ranging from $\$ 2,000.00$ to $\$ 3,000.00$ per orchard, and 
due entirely to rust, were very common throughout the eastern portion of the State in 1912, while there were many smaller losses and quite a number of larger ones. Careful and conservative estimates indicated a direct fruit loss of at least $\$ 75,000.00$ in one county the latter season. The seasons of 1912 and 1914 were noteworthy on account of the large amount of fruit infection while the rust on foilage was especially serious in $1910,1912,1915$, and 1917.

The studies of this disease have included some detailed observations as to its injurious effects on apples, apple trees, and cedar trees, and these data will be given on a later page.

\section{LIFE HISTORY OF THE FUNGUS}

Gymnosporangium juniperi-virginianae is a heteroecious rust having the red cedar, Juniperus virginianue, and species of apple, Malus , as hosts. On the red cedar it appears in the form of corky galls, commonly known as "cedar apples" (Plate III, Fig. 5). In this latitude the galls first become apparent during June, continue to grow through the summer, and almost reach maturity by late autumn. With the first warm weather of spring they develop numerous brownish projections known as sori (Plate I, Fig. 1). Each sorus is composed of many two-celled teliospores more or less imbedded in a gelatinous matrix (Plate 1, Fig. 3).

Under favorable weather conditions, with sufficient moisture, these sori swell into large, finger-like projections (Plate I, Fig. 2). Each cell of a teliospore may then send out a promycelium. This promycelium quickly divides into four cells each of which produces a secondary spore or sporidum (Plate I, Figs. 4 to 6 ). As soon as the humidity decreases enough to cause appreciable evaporation the sporidia are forcibly discharged (Plate II, Figs. 1 and 2 ) as stated by Coons (1912, p. 230)*.

The teliospores do not all germinate at once and sporidia may be discharged several times during the season. They are readily carried about by air currents and deposited on the foliage of any nearby apple trees. Sporidia which find their way to the young foliage or fruit of susceptible apple varieties, under favorable weather conditions, will germinate and enter the host tissues.

The rust spots first become visible upon the upper surface of the leaves, and in about ten days after infection has taken place. $\dagger$ At this

\footnotetext{
* The forcible ejection of sporidia was independently observed by the author during the spring of 1912. In a number of cases it was noted that there was an abrupt sidewise movement of the sporidium several seconds previous to its discharge. This movement was believed to indicate the rupturing of an outer wall or membrane at the base of the sporidum, but the studies were not made in sufficient detail to warrant any general conclusions.

t Our records show that inoculations made April 14, 1.913 gave clearly visible spots in 16 days, while the infection which took place May 15 th produced spots in 12 days. In 1914 the infection of April 26 th became apparent in 11 days and visible spots developed from the infection of May 5 th in 9 days.
} 
time they are pale yellow spots about the size of a pin head. They assume a darker shade of yellow as they enlarge (Plate II, Fig. 3). On some of the more susceptible varieties these spots sometimes become half an inch in diameter by the end of the season.

In about two weeks after the first appearance of the spots, little raised specks appear near the center of them. These are the openings of the flask-shaped pycnia (Plate II, Fig. 4). The sticky, darkorange exudate which may be seen on the rust spot at about this time contains the pycniospores (Plate II, Fig. 6). As far as is known they irave no important bearing on the life history of this fungus. Soon after the pycniospores have been discharged, the pycnia become apparent as small black spots (Plate II, Fig. 5).

On the lower surface of the spot, hypertrophy takes place, proAucing a swelling considerably elevated above the normal leaf surface. During the months of July and August bodies known as cluster cups, which bear the aeciospores, break through these swellings (Plate III, Figs. 1 to 4 ). The aeciospores of this fungus are not capable of producing reinfection of the apple, but may be carried back to the cedar where they lodge in the axils of the tiny leaf scales producing an infection in the young growth of the cedar (Plate III, Fig. 5). No ontward indication of such cedar infection can be observed until the following season which shows that the fungus spends about twenty-one months of its life cycle on the red cedar.

\section{METHODS OF STUDYING FIELD INFECTIONS}

The first problem in regard to natural field infections was to learn when they took place. An analysis of the situation led to the conclusion that the only reliable way to get at it was to use paper sacks to prevent infection of certain twigs between definite dates. One hundred and twenty apple twigs were usually so covered with No. 20

\section{PLATE I}

Fig. 1.-Rust gall of Gymnosporangium juniperi-virginianae on red cedar, with mature teliosori. These sori have never been moistened (about $2 / 3$ natural size).

Fig. 2.- Same gall as shown at right in Fig. 1, but after moistening for about 3 hours (about $2 / 3$ natural size).

Fig. 3.-Mature teleutospores with pedicels $(X 240)$.

Fig. 4.- Teleutospores taken 1 hour and 20 minutes after first moistening. Note early development of promycelium $(X, 240)$.

Fig. 5.-Teleutospores taken 1 hour and 45 minutes after first moistening a soras. The promycelium is well developed $(X 240)$.

Fig. 6.-Teleutospores taken 2 hours and 15 minutes after first moistening a sorus. The promycelium has divided into four celis with distinct walls and nuclei $(X 240)$. 
PLATE I

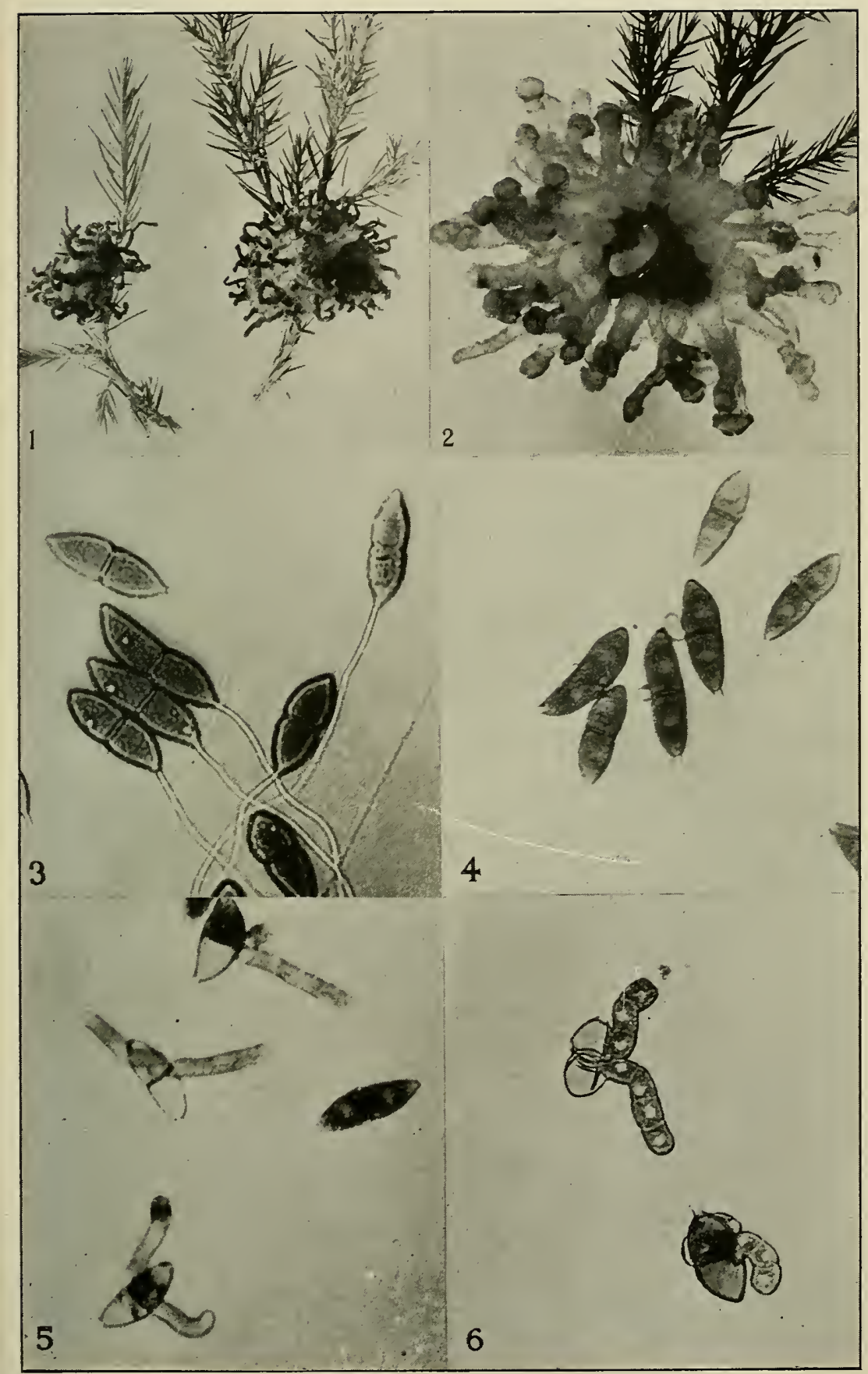


sacks soon after the leaf buds began to open. The next day, eight of these twigs were uncovered and eight new twigs were covered. This process was continued until the original lot of twigs were all exposed. The same system was repeated with the twigs now covered, but removing each day those sacks which had been on longest. Thus if infection took place May 5 th, the twigs sacked the 4th would not show it, while those sacked the 6 th would. Inversely those unsacked the 4 th would be infected, while those unsacked the 6 th would not. This sacking method proved very satisfactory and helped to clear up many questions in regard to field infections. It requires only a little time each day, but it must be done regularly, and in most of this work half of the sacking for any day was done early in the morning and half was done late in the afternoon.

Other common methods such as exposure of plates and cards were tried at the same time but were found to be very unreliable in the case of this disease, and required fully as much time as the sacking experiments. In fact, there may be dissemination of sporidia without infection; and, as will be seen later, there may be abundant sporidia discharge without appreciable dissemination.

Numerous inoculations were made in the field as well as in the greenhouse, and water suspensions of the sporidia were not found uniformly successful for this work. More satisfactory results were secured by suspending the rust gall near the top of a moist chamber and allowing the sporidia to be carried onto the leaves in a current of air, after which the leaves were moistened to insure infection.

\section{FACTORS WHICH INFLUENCE INFECTION OF APPLE}

It was believed that a more definite knowledge of the conditions which bring about rust infection of the apple under field conditions would be of value, and some attention has been devoted to this matter. These conditions readily fall under four main heads:

1.-Development of rust galls on the cedar.

2.- Meteorological conditions.

3.-Development of apple foliage.

4.- Location of orchard with relation to cedars.

\section{PLATE II}

Fig. 1.-Teleutospores taken 3 hours after first moistening a sorus. Note sporidia formation $(X 240)$.

Fig. 2.--Sporidia discharged upon slide 3 hours and 15 minutes after first moistening $(X 240)$. In several instances there was abundant discharge in less than 3 hours, but photographs were not secured.

Fig. 3.-Mature rust spots on apple leaf, upper surface view. (Reduced).

Fig. 4.-Upper surface of rust spot on apple leaf 16 days after inoculation. Note exudate from pycnia (X 11.5).

Fig. 5.-Upper surface of rust spot on apple leaf 20 days after inoculation. Exudation has ceased from most of the pycnia and they have turned black ( $\times$ 11.5).

Fig. 6.-Pycniospores $(\times 240)$. 
PLATE II.

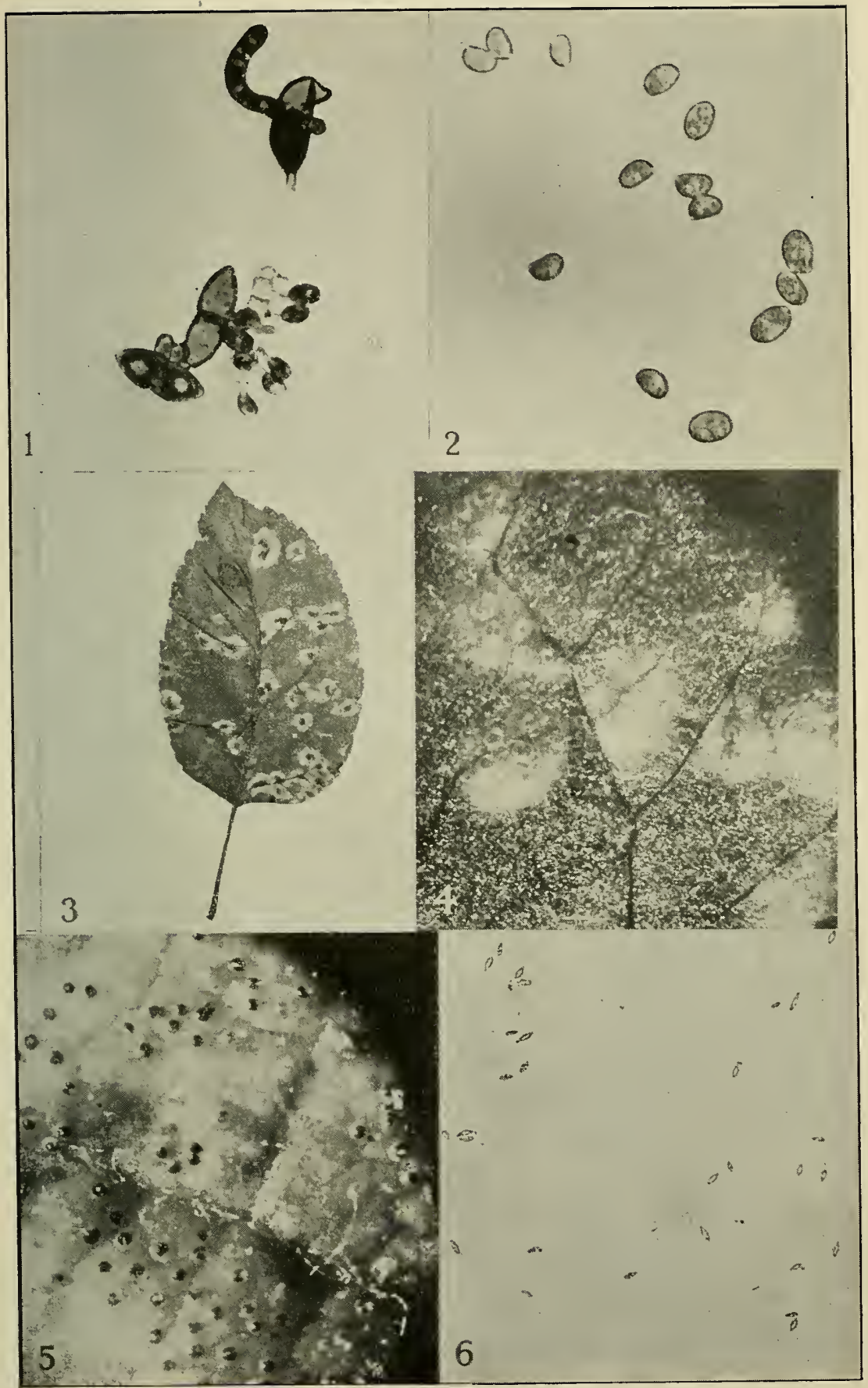


The normal rust galls of G. juniperi-virginianae as they occur on the red cedar in West Virginia are capable of discharging large numDers of sporidia at almost any time from the first of April to the first of June. This period varies considerably with different seasons, but the fruiting bodies are always well developed by the time that the apple buds begin to open, and slight rust infections often occur as late as the first week in June.

The ability of the rust galls to produce and discharge sporidia is closely associated with meteorological conditions. Considerable difficulty was experienced in the author's endeavors to determine accurately the interrelation of meteorological factors with infection periods. Some general notes were made as to weather conditions during the season of 1912. These records were as good as could reasonably be secured under the circumstances. Data covering the critical period for that season show that there was fair weather from the 1st to the 5 th of May, a light shower on the afternoon of May 5th, fairly heavy rains from the afternoon of May 6th to the afternoon of May 8 th, and fair weather from the 9 th to the 11 th. The important rust infection for 1912 took place between the evening of the 6 th and the afternoon of the 8th of Mav. There was a slight earlier infection and another about the last of May or the first of June.

During the season of 1913 a barograph and a hygrothermograph were added to the meteorological equipment (Plate XI, Fig. 2). These gave a continuous record as to the temperature, humidity, and atmospheric pressure. Cold, rainy weather was prevalent most of the time from April 10th to 16 th and a considerable number of sporidia were discharged on the 13 th. The recording instruments were not set up until April 14th so that the exact thermal and moisture conditions associated with the spore discharge on that date are not known. It might be noted that there were very few apple leaves infected at this time and this is readily accounted for by the fact that the average length of the buds was only $3 / 8$ inch to $1 / 2$ inch.

On April 18th there was a thunder shower, but this had little effect on the cedar galls. York Imperial apple trees were in full bloom April 25th and 26th.

April 2\%th there was an intermittent rain throughout the day and there had been some rain the preceding night, but there was no evidence of sporidia discharge or apple leaf infection as a result. The

\section{PLATE III}

Fig. 1.-Mature rust spots on apple leaf. Lower surface view (reduced).

Fig. 2.-Young aeciosori taken 64 days after inoculation $(X 5)$.

Fig. 3.-Mature aeciosori. They are open and many of the aeciospores are gone $(X 11.5)$.

Fig. 4.-Aeciospores $(X 240)$.

Fig. 5.-Cedar twig with numerous galls of various sizes. 


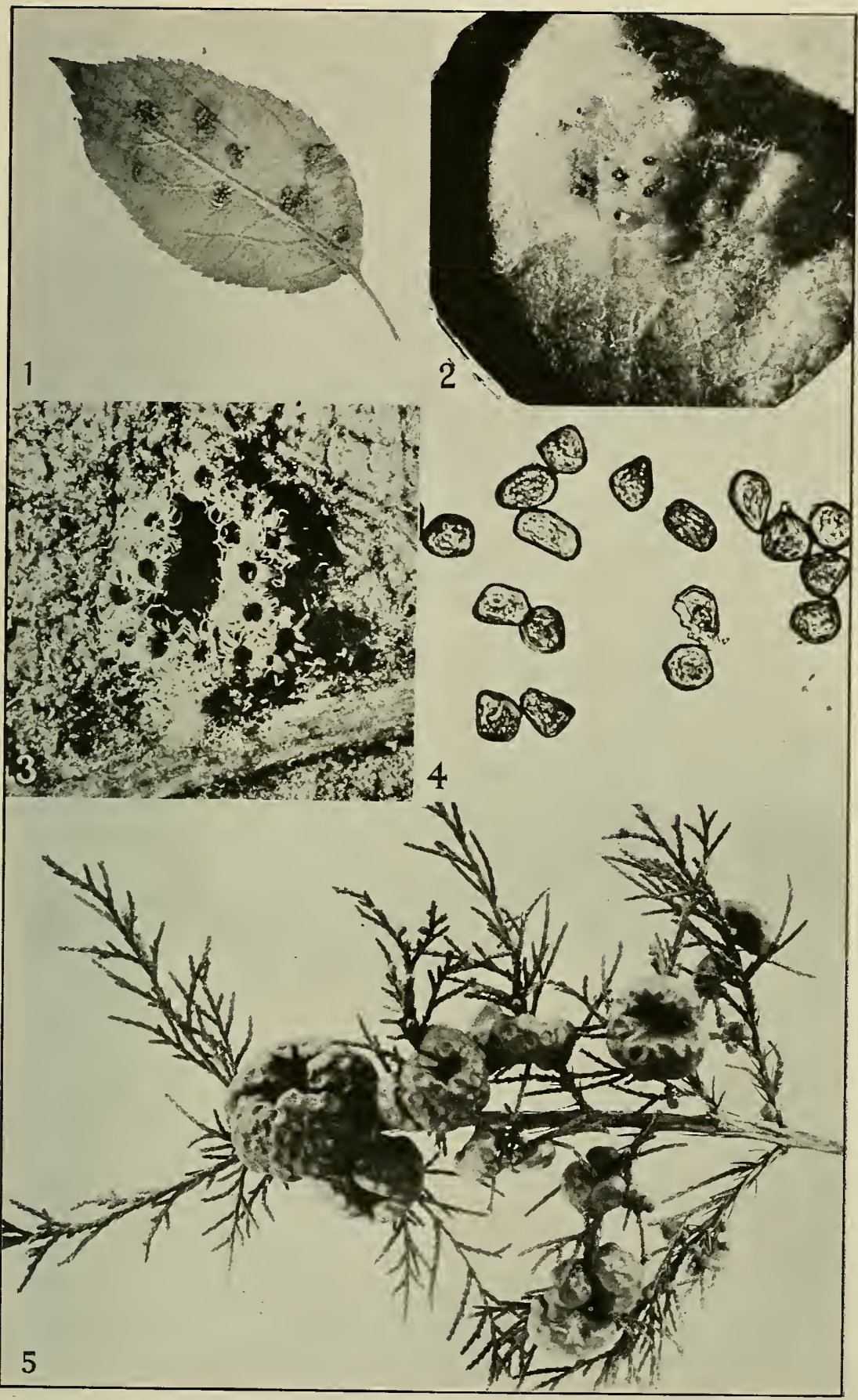


relatively low and decreasing temperature which prevailed during that day and until ten o'clock the next morning may have prevented sporidia discharge until the sori had dried up sufficiently to hinder it.

A section of the chart showing humidity and temperature for that period is reproduced below.
FRIDAY.
SATURDAY.
SUNDAY.

TEMPERATURE HOUR LINES INDICATED IN TOP MARGIN

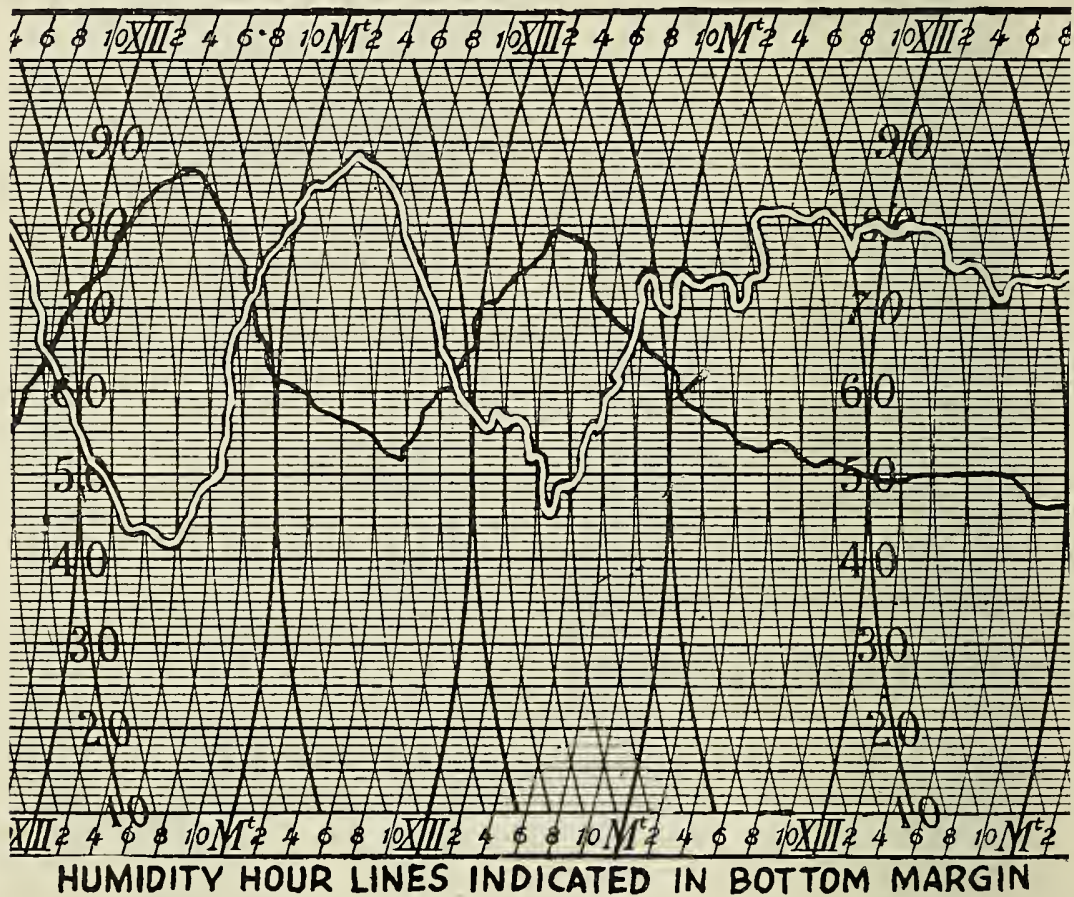

Hygrothermograph Record from Friday, April 25th, to Sunday, April 27th, 1913. Double Line is Humidity and Single Line is Temperature.

There was no more rain until the morning of May 14th but it continued for about three to five hours at that time. In the afternoon it was cloudy and sporidia were discharged from the cedar apples in great numbers. White cards exposed just below good sized rust galls showed a very distinct yellow coating in two hours. There was no evidence of apple infection as a result of the sporidia discharge which took place that afternoon. Twigs of York Imperial apple trees that were covered with sacks on the morning of May 15th were as well

\section{PLATE IV}

Fig. 1.-Rust gall with expanded sori, as it appears in field after a rain. Fig. 2.-Mature aecia on a wild crab apple twig. 


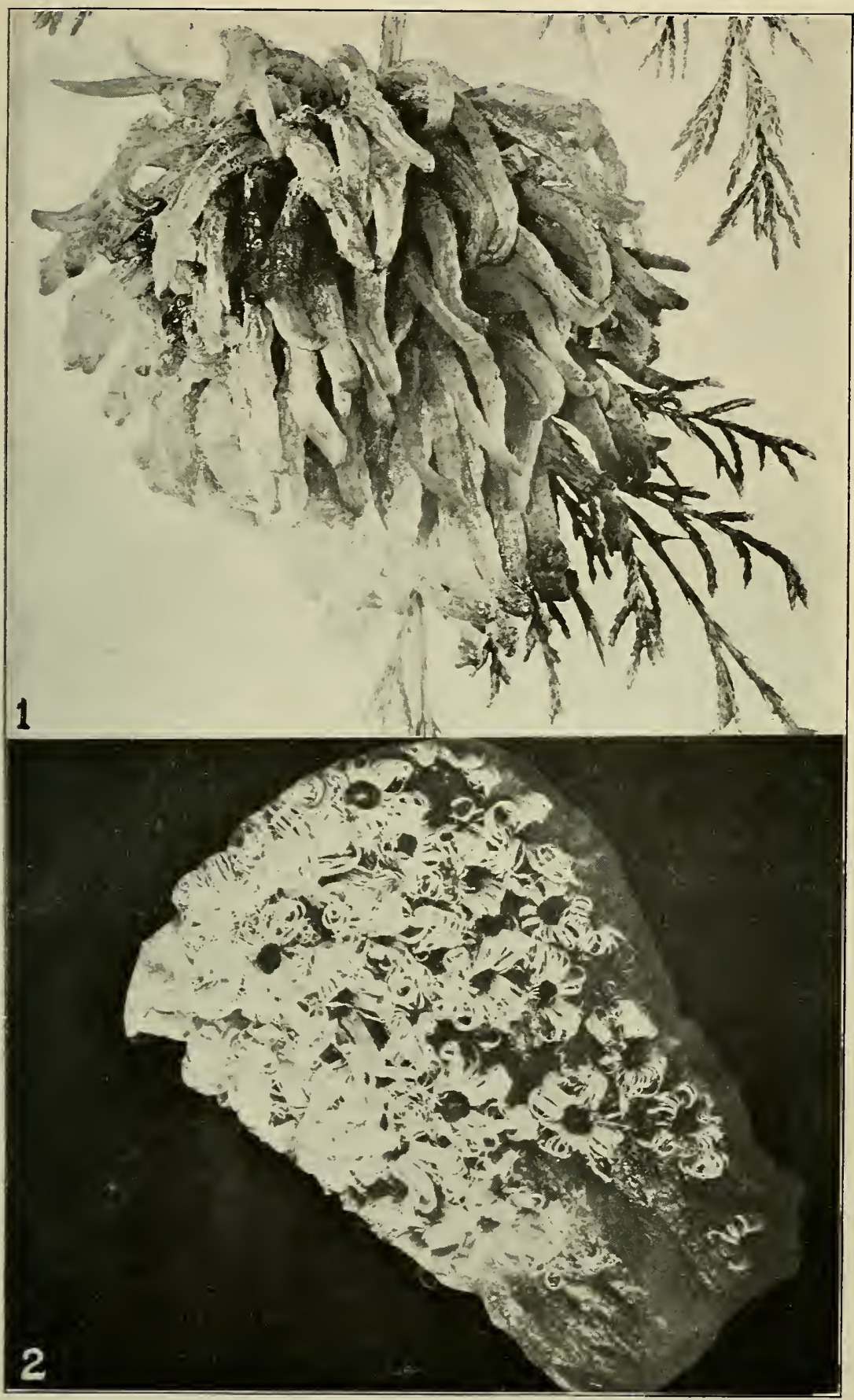


protected from the rust as others right beside them which were sacked on the 14 th. Conversely, twigs which had been previously sacked for two weeks to exclude rust infection and which were uncovered on May 14th showed no more rust than similar twigs uncovered on the 15 th. This can only be accounted for by the quiet condition of the air during the afternoon of May 14th. In the weather records covering that day it is stated as impossible to detect any air stirring during the afternoon. It should be noted that these apple trees were within ten rods of large cedars which were literally loaded with rust galls.

It rained again during the night of May 14 th-15th, and there was abundant sporidia discharge from about $10 \mathrm{~A}$. M. to $2 \mathrm{P}$. M. of the 15 th. The only serious rust infection for the season of 1913 occurred at this time. There was a light wind and it was somewhat variable.

The humidity gradually dropped about 15 per cent during the period of the most active sporidia discharge on May 14 th and there was a slight rise in temperature during that period. Similar data may be noted on the chart for May 15th, except that the drop in humidity was considerably greater and the rise in temperature was more pronounced than on the previous day. A section of chart showing tracings for May 14th and 15th, 1913, is shown below.

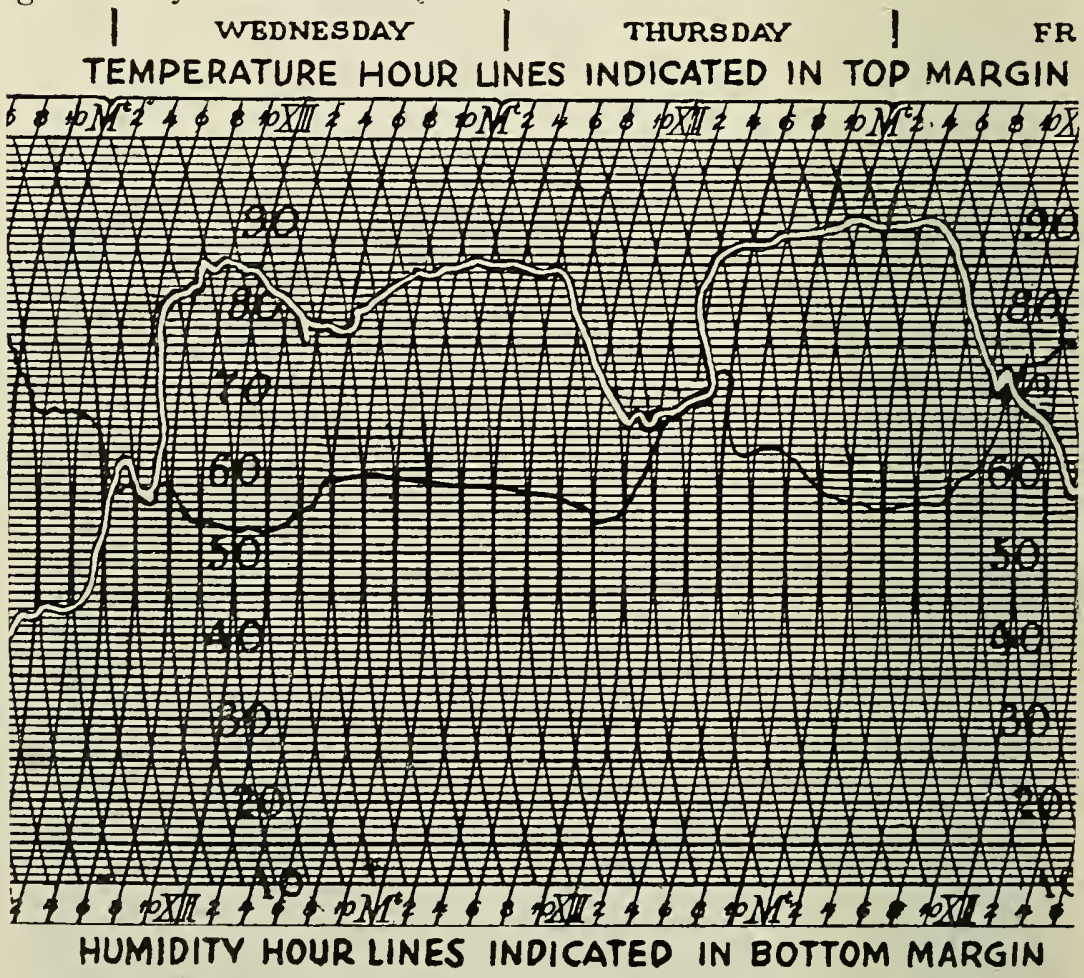

Hygrothermograph Record from Wednesday, May 14th, to Friday, May 16th, 1913. Double Line is Humidity and Single Line is Temperature. 
Rain occurred again on May 1\%th, but there was no evidence of infection following it. Twigs which had previously been sacked and were uncovered on the 16 th were as well protected as were those uncovered on the 19 th. The humidity and temperature conditions would appear to have been very good for sporidia discharge, but we have no records as to air movements. It is possible that many sporidia were set free and that they settled quickly to the ground, as on May 14th, but it is far more likely that only a very few were discharged since the sori on the cedar galls were much reduced in size and evidently becoming exhausted. Careful observations as to actual spore discharge were not made on this date. The section of chart for May 17th and 18th is given below.

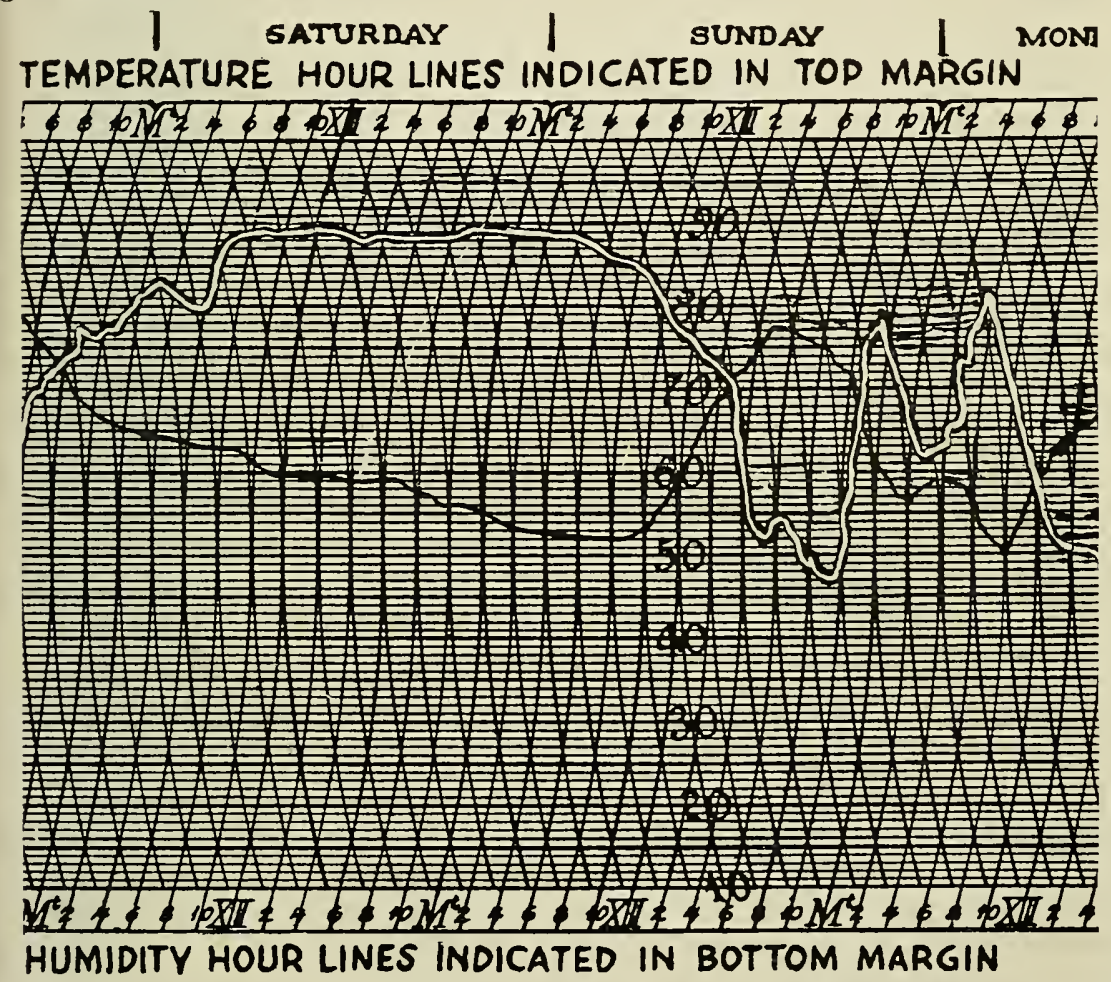

Hygrothermograph Record from Friday, May 16th, to Sunday, May 18th, 1913. Double Line is Humidity and Single Line is Temperature.

Local showers occurred on the 21st and $22 \mathrm{nd}$, but were of short duration and did not have much effect on the cedar galls. May 23rd there was rain all day, but no special observations were made as to discharge of sporidia. Sacking experiments gave evidence that no infection took place on this date.

It began raining again on the evening of May 26th and continued most of the time during that night and the next day. A number of 
apple leaves became infected with rust on the $2 \%$ th and possibly a few received infection on the 28th. It is believed that the principal and possibly the only sporidia discharge took place between $4 \mathrm{P}$. M. and "P. M. on Tuesday, the $2 \%$ th. A drop in humidity and a rise in temperature will be noted for that period in the chart below.

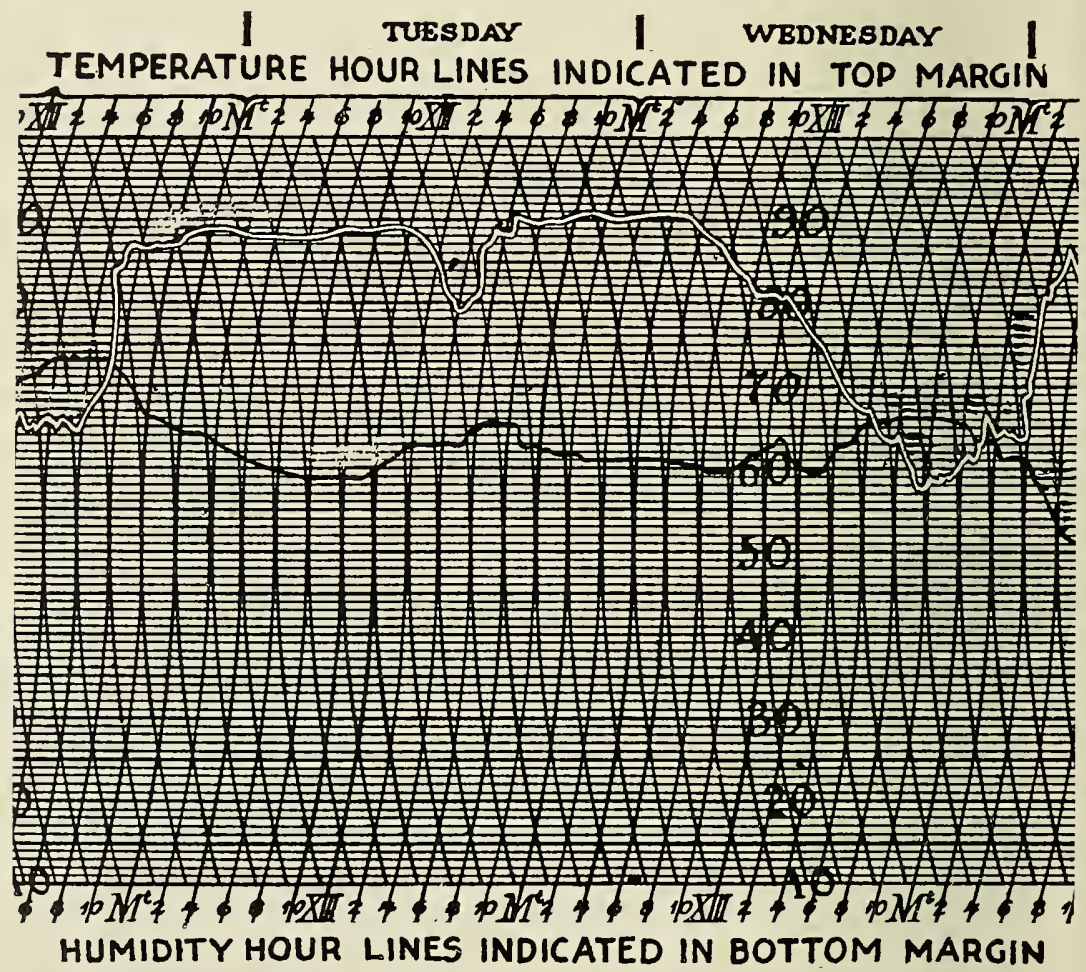

Hygrothermograph Record from Monday, May 26, to Wednesday, May 28th, 1913. Double Line is Humidity and Single Line is Temperature.

Practically all of the sori dried up and dropped off from the cedar galls soon after this date and no further observations were made on them.

The importance of the wind in dissemination of rust and the difficulty of making accurate observations along this line were clearly

\section{PLATE V}

Fig. 1.-Rust galls of various sizes as they appear during winter.

Fig. 2.-Rust galls of various sizes with expanded, gelatinous sori. Note small galls on single needles at right (about natural size).

Fig. 3.-Larger rust galls with expanded, gelatinous sori (about natural size). 
PLATE V

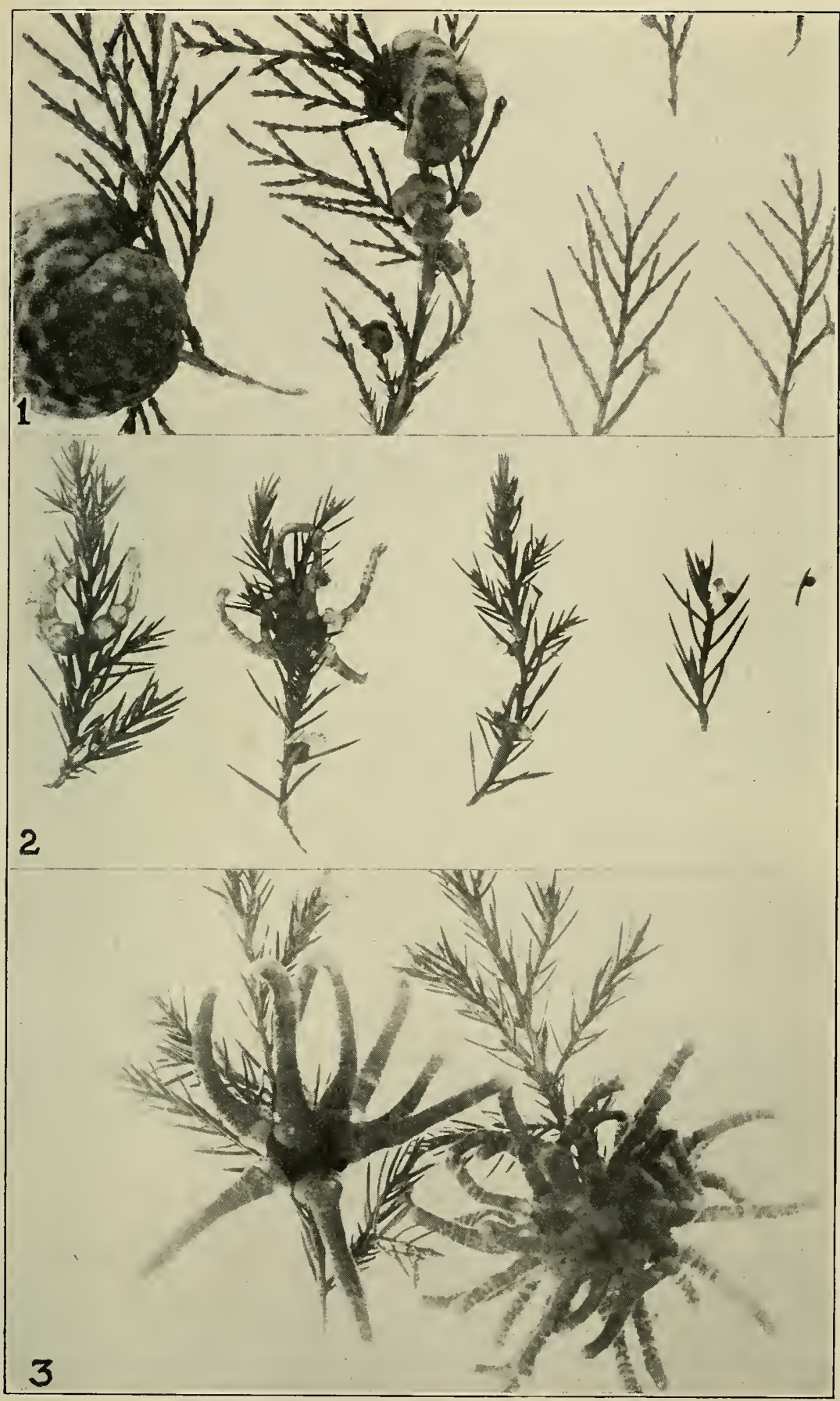


shown by the work during 1913. In order to secure such data the meteorological equipment was again increased by securing a quadruple register, tipping bucket rain gauge, electric sunshine recorder, anemometer, and wind vane (Plate XI, ${ }^{2}$ Fig. 1). This outfit gave almost continuous records as to rainfall, sunshine, wind velocity, and wind direction. The practical data secured with the aid of these instruments are very valuable. The records for the growing season of 1914 begin with April 23rd.

There was no rain from April 21st to April 25th. It began raining the morning of April 25th and continued intermittently all day. This was followed by very heavy showers in the evening and a steady rain which lasted until 9 A. M. of April 26th. Sporidia were discharged in great numbers between 9 A. M. and 12 M. on Sunday, April 26th. The quadruple register records for this period of spore discharge show a variable wind having a general southeast to southwest direction; average wind velocity of about four miles per hour; and continuous sunshine after $10 \mathrm{~A}$. M. A section of this chart is shown below :

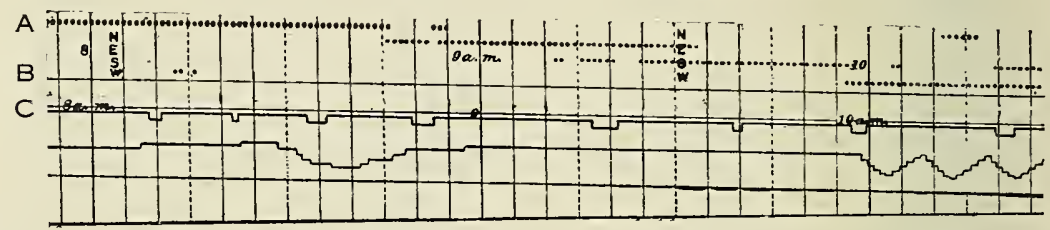

Section of Quadruple Register Chart Showing Wind Direction, Wind Velocity,

Rainfall, and Sunshine from 8 A. M., April 26th, to 10:30 A. M. April 26th,

1914. A Indicates Wind Direction; B, Wind Velocity; C, Rain Until 9 A. M. and Sunshine After 10:00 A. M.

The hygrothermograph record shows a rather rapid fall in humidity and an equally abrupt rise in temperature. The section of the chart for Saturday, April 25th, and Sunday, April 26th, is given (p. 23).

A general infection of apple foliage took place at this time, but it was not serious because there were only a few leaves unfolded. The blossom buds were just beginning to show color on April 26th and the central blossom did not open until May 1st. The leaves which enclose the blossom clusters were opened out sufficiently to receive infection and it was very noticeable on all the trees sprayed May 4th that the leaves which came from a fruit bud were all quite heavily infected while those from a leaf bud did not show as much rust. Twigs covered with sacks on the afternoon of April 26th and uncovered on May 10th showed the extent of this infection.

It should be noted that a very light wind was sufficient to disperse the sporidia.

A shower occurred on the afternoon of April 29th, but did not have much effect on the cedar galls.

There was a shower about 5 P. M. on May 4th, and this was followed by a light rain from $6: 30 \mathrm{P}$. M. to $11 \mathrm{P}$. M. The hygrothermograph record covering May 4th and 5th showed a drop of from 10 per 


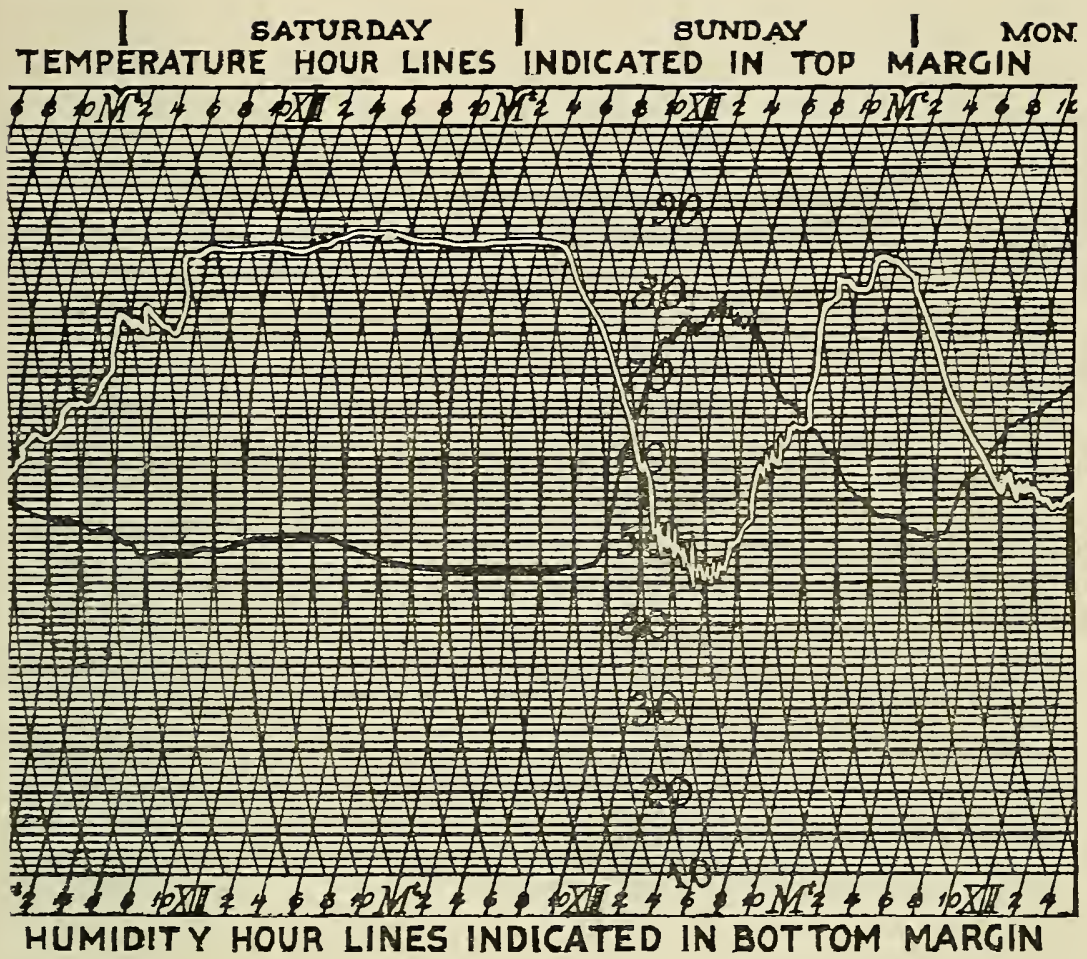

Hygrothermograph Record from Saturday, April 25, to Monday, April 27th, 1914. Double Line is Humidity and Single Line is Temperature.

cent to 15 percent in humidity between midnight and $2 \mathrm{~A}$. M. May ǒth. It began raining again at about $2: 30 \mathrm{~A}$. M. May 5 th and continued until $10 \mathrm{~A}$. M. of the same day.

A section of the record from the quadruple register is given below :

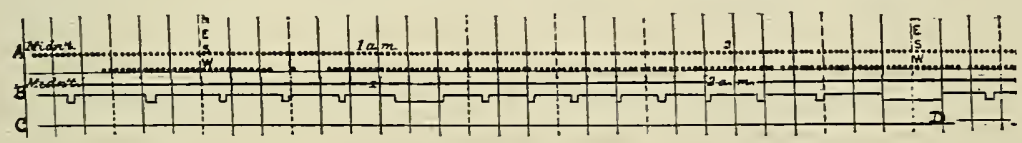

Section of Quadruple Register Record from Midnight, May 4th, to 2:45 A. M. May 5th, 1914. A Indicates Wind Direction; B, Wind Velocity:

C, Sunshine Line; D, Rainfall.

York Imperial twigs sacked immediately after it stopped raining on the morning of May 5 th were just as badly diseased with rust as unprotected twigs on the same tree. Trees sprayed about $11 \mathrm{~A}$. M. that day showed just as much rust as unsprayed trees. The sporidia discharge had occurred between 12 and 2:30 A. M., May 5th, and the infection of apple foliage and fruit had evidently taken place at once. 
The wind which carried the sporidia was in a general southwest direction, varying to south, and with a velocity of about ten miles per hour. Jnfection was general and quite severe.

There was no evidence of sporidia discharge during the forenoon of May 5th, although careful observations were made by exposing large watch glasses near the cedar galls for from one to six hours. The sporidia, if discharged in any numbers, would alight on the watch glasses, and their presence could easily be detected with a microscope.

On May 8 th it rained from about $8: 30$ A. M. until 12:30 P. M. and there were showers during the latter part of the afternoon and until $7: 30$ P. M. Sporidia were discharged during the night but there was no evidence of infection occurring at this time. 'The wind direction was extremely variable during the night of May 8th and 9 th and its velocity was only $1 \frac{1}{2}$ to 2 miles per hour.

There was another shower late in the afternoon on May 12th, but it was of short duration and no sporidia discharge was noted. Light showers occurred on May 28th, 30th and 31st but no evidence of sporidia discharge or infection was noted as a result. The humidity ranged very low throughout the period from May 12th to June 4th and the temperature was comparatively high most of the time.

It rained during the forenoon of June 4 th, and beginning again at 4. P. M. that day, it rained intermittently all night. There was a slight, but rather general infection of apple rust at this time. The wind direction was south varying to southwest.

The sori on the cedar rust galls were nearly exhausted by this date, and there was no further evidence of sporidia discharge or infection.

Similar data for 1915 are of considerable interest since there was a greater amount of rust on the foliage and the principal infection occurred later in the season. A suitcase containing very important notes on sacking experiments, condition of rust galls, and sporidia discharge, was stolen during a trip the latter part of the season.

Sacking experiments were conducted in two orchards about 22 miles apart which orchards will be designated as the Thompson orchard and the Dodd orchard. There was no important natural harrier between them, and no apparent reason for suspecting that there would be much difference in the weather conditions or that the rust infection in the two orchards would occur at different times. Detailed weather records were secured from the Thompson orchard while hygrothermograph records and some general notes as to rainfall and wind were taken in the Dodd orchard.

Between April 20th and May 13th there were nine distinct periods of precipitation at the Thompson orchard. Three of these periods showed a rainfall of such amount and duration as to indicate sporidia discharge from rust galls, yet the records show only two infections at that place. There was a local but rather severe infection in the Dodd orchard during the night of April 18-19, but twigs sacked April 18th were free from rust showing that there was no infection previous to that date. A more general but comparatively light infection took 
place on April 29th at which time the York Imperial apple trees were just about in full bloom. A very heavy infection was looked for as a result of the rain at this time. It is assumed either that the continually decreasing temperature was unfavorable to sporidia discharge during the night or that it inhibited their germination. Any sporidia which had not penetrated into the leaf tissue before 9 A. M. on April 29th were undoubtedly killed by the long period of comparatively low humidity which followed (See chart for April 28th to April 30th, 1915).

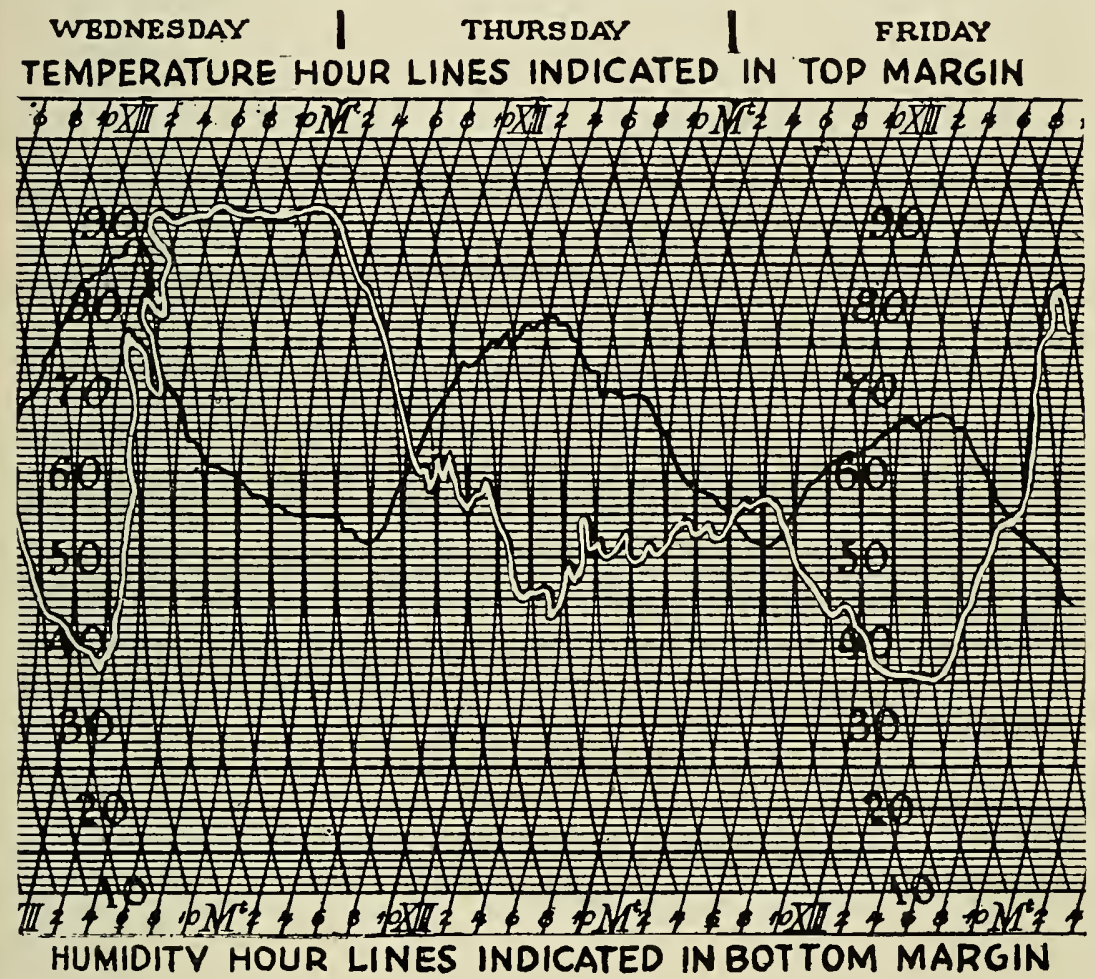

Hygrothermograph Record from April 28th, to April 30th, 1915. Double Line is Humidity and Single Line is Temperature.

There were some fairly heavy showers followed by a light rain the evening of May 3rd, but there was little, if any, infection as a result. Here again the temperature dropped rapidly enough to somewhat inhibit sporidia germination. As soon as the temperature began to rise there was a sudden and remarkably pronounced drop in humidity. As will be noted on the following chart the temperature attained $84^{\circ} \mathrm{F}$. while the humidity decreased to 27.5 per cent within a few hours and this combination was doubtless sufficient to destroy any sporidia present on the apple foliage which might otherwise have 
remained alive until temperature and moisture were favorable for germination and infection.

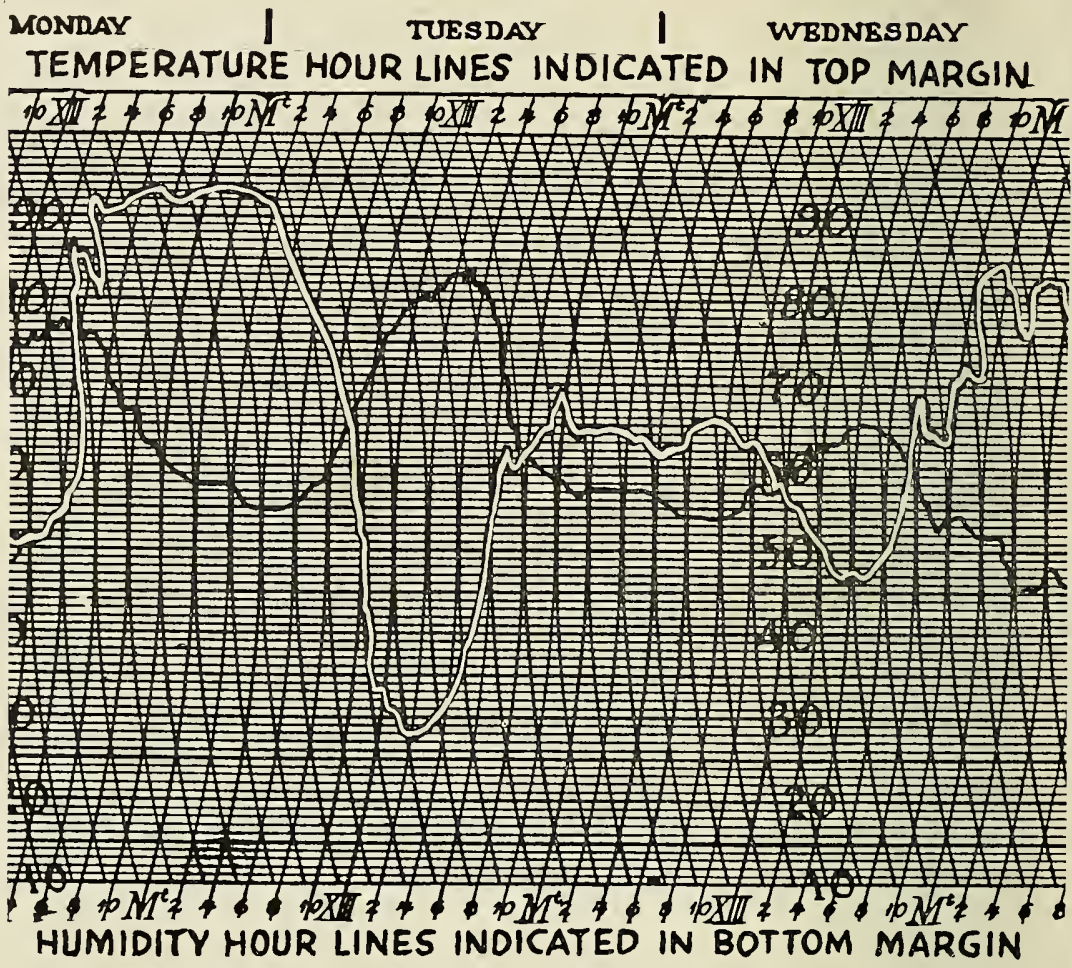

Hygrothermograph Record from May 3rd to May 5th, 1915. Double Line is Humidity and Single Line is Temperature.

It began raining about daylight the morning of May 1.2th and continued, with some slight intermissions, until midnight of that night. Some infection had occurred before 6:00 o'clock P. M. May 12th and before 10:00 o'clock on the morning of the 13th there was a very severe and quite general infection of all susceptible foliage. Two noteworthy features in the weather for that period are the comparatively slight but gusty wind and the very uniform temperature. If this infection had occurred about ten days earlier it would have been disastrous to many orchards, but fortunately the first five leaves were immune or nearly so. The relative amounts of infection occurring on April 28 and 29 and on May 12 and 13 may be noted from Table VII on page 45 .

The rust galls were practically all exhausted by May 15th and no further detailed records were kept, but there was evidence of another infection in the Dodd orchard on May 21st.

In 1916 the meteorological equipment was moved from Summit Point, West Virginia, to Martinsburg, W $\mathrm{W}^{\top}$ est Virginia, so that the 


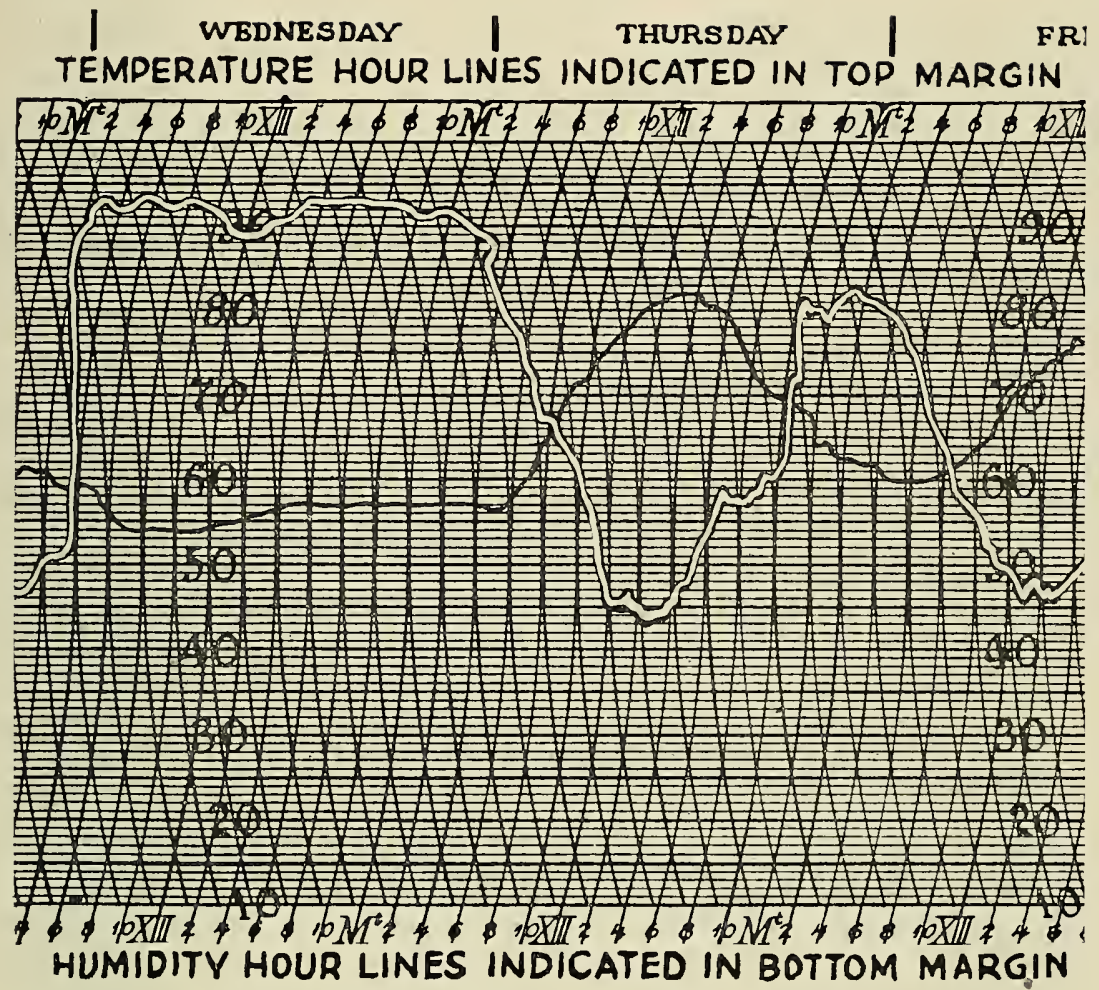

Hygrothermograph Record from May 12th to May 14th. 1915. Double Isine is Humidity and Single Line is Temperature.

records might be of more value in connection with some other phases of the work. A hygrothermograph should still have been maintained at Summit Point, for there is always a fairly uniform infection in the Thompson orchard and our records for 1916 and 1917 were not so satisfactory for accurate study of the correlation between weather, sporidia discharge, and local infection.

The rainfall for the month of May, 1916, was considerably below normal in that section of West Virginia and there were only two periods during the entire month when moisture conditions were reasonably favorable for sporidia discharge under field conditions. On three other dates the amount and duration of actual rainfall was sufficient but a high degree of humidity was not maintained for a sufficient time afterward to have resulted in any appreciable sporidia discharge except under ideal temperature conditions. On the night of May 22nd-23rd there was continuous rain for at least ten hours and the only noticeable general infection occurred at that time. York Imperial apple trees were in full bloom May 3rd and the first five large leaves were practically immune on the $23 \mathrm{rd}$ as may be noted from Table VII. The amount of infection on susceptible foliage was much 
less than usual and this was doubtless due to the prevailing low temperature. The thermograph registered $51^{\circ} \mathrm{F}$. during the entire period of rainfall and it ranged from $52^{\circ} \mathrm{F}$. to $64^{\circ} \mathrm{F}$. for 36 hours afterward. No attempt is made to reproduce the hygrothermograph record for that period as it is not all on one chart and there are some confusing marks which it seems difficult to eliminate.

There was heavy rain again during the night of May 29th-30th, but no evidence of infection as a result of it. Most of the apple foliage was immune at this time and no further detailed infection notes were taken.

The spring months of $191 \%$ were quite unusual in that the season advanced rapidly during late March and early April, but received a severe setback during the latter part of April and the month of May. Rain was recorded on twelve days between April 22nd and May 26th and there were several days when the moisture conditions would have been considered ideal, but the temperature was low enough to prevent sporidia discharge or germination. A section of chart showing one such period of rain and mist for May 9th and 10th is shown below. The hygrograph was running six percent too high at this time.

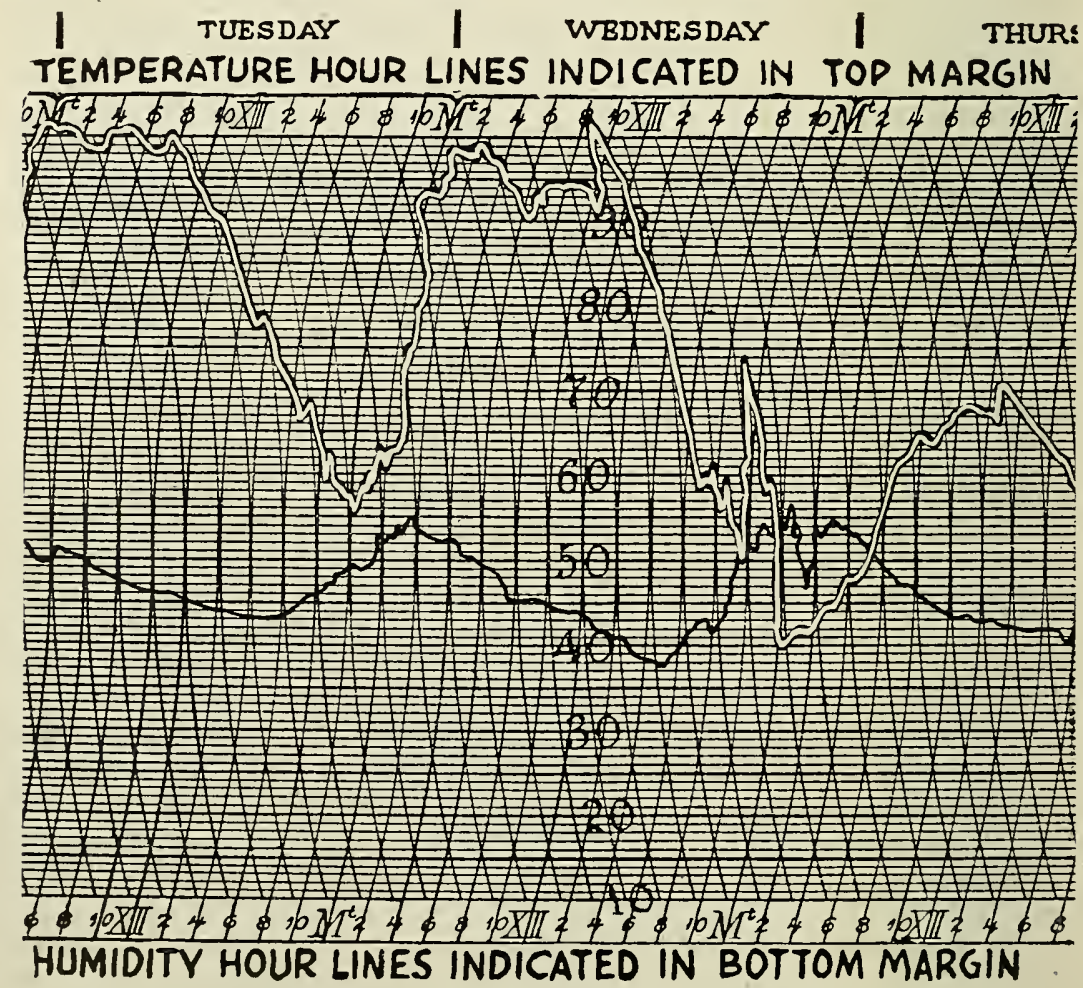

Hygrothermograph Record from May 9th to May 11th, 1917. Double Line is Humidity and Single Line is Temperature. 
On May 2ith and May 28th there were heavy showers and rain giving a total rainfall of 1.98 inches. Showers early on the morning of the 2\%th were not of sufficient duration and were followed by bright sunshine with a very rapid rise in temperature to nearly $90^{\circ} \mathrm{F}$. Rain during the night of May $2 i$ th-28th resulted in the first general rust infection of the season, and it was a comparatively light one. Sections from the two charts covering this period are shown below.

I SUNDAY I MONRAY
TEMPERATURE HOUR LINES INDICATED IN TOP MARGIN

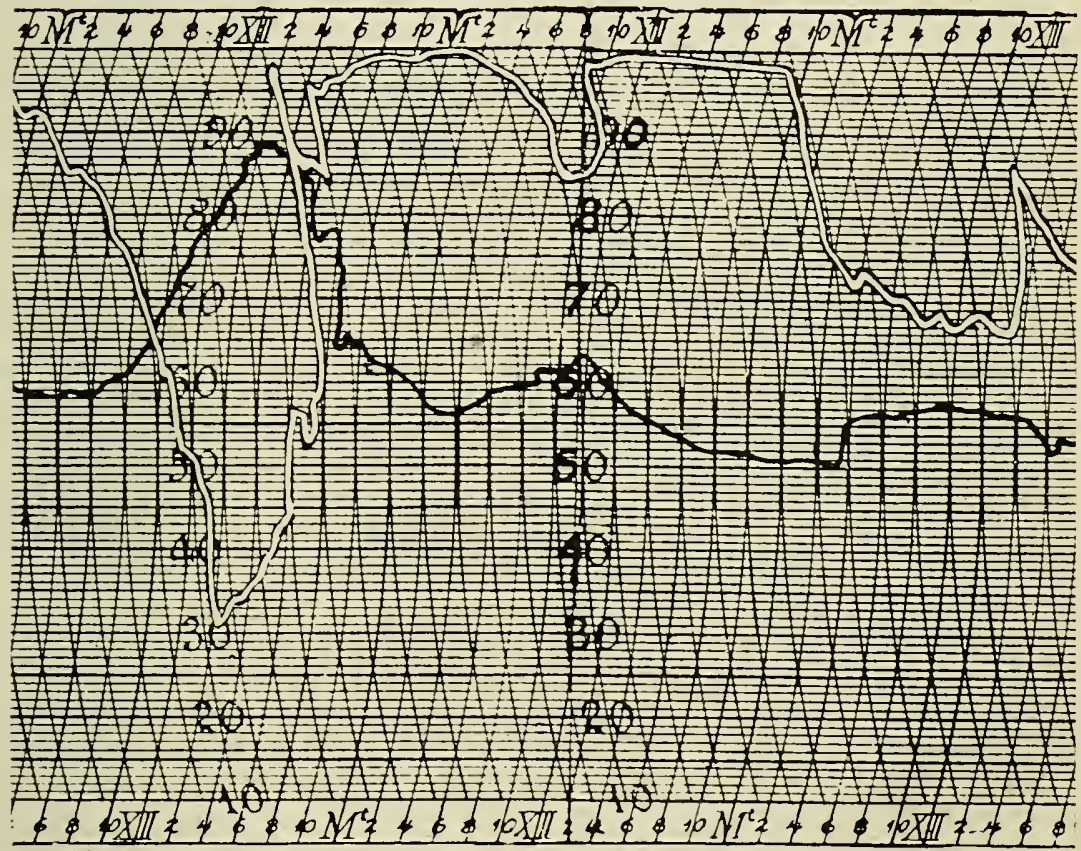

HUMIDITY HOUR LINES INDICATED IN BOTTOM MARGIN

Hygrothermograph Record from May 27th to May 29th, 1917. Double Line is Humidity and Single Iine is Temperature.

There was a slight local infection on June 1st in one orchard under observation, but the principal rust infection of the season of $191 \%$ occurred during the morning of June 7 th. Although it was very late in the season and more than five weeks after the trees were in bloom, there were only four to five large leaves immune at this time; and 
many leaves were severely infected as may be noted in Table VII. A section of the hygrothermograph chart for this period is given below.

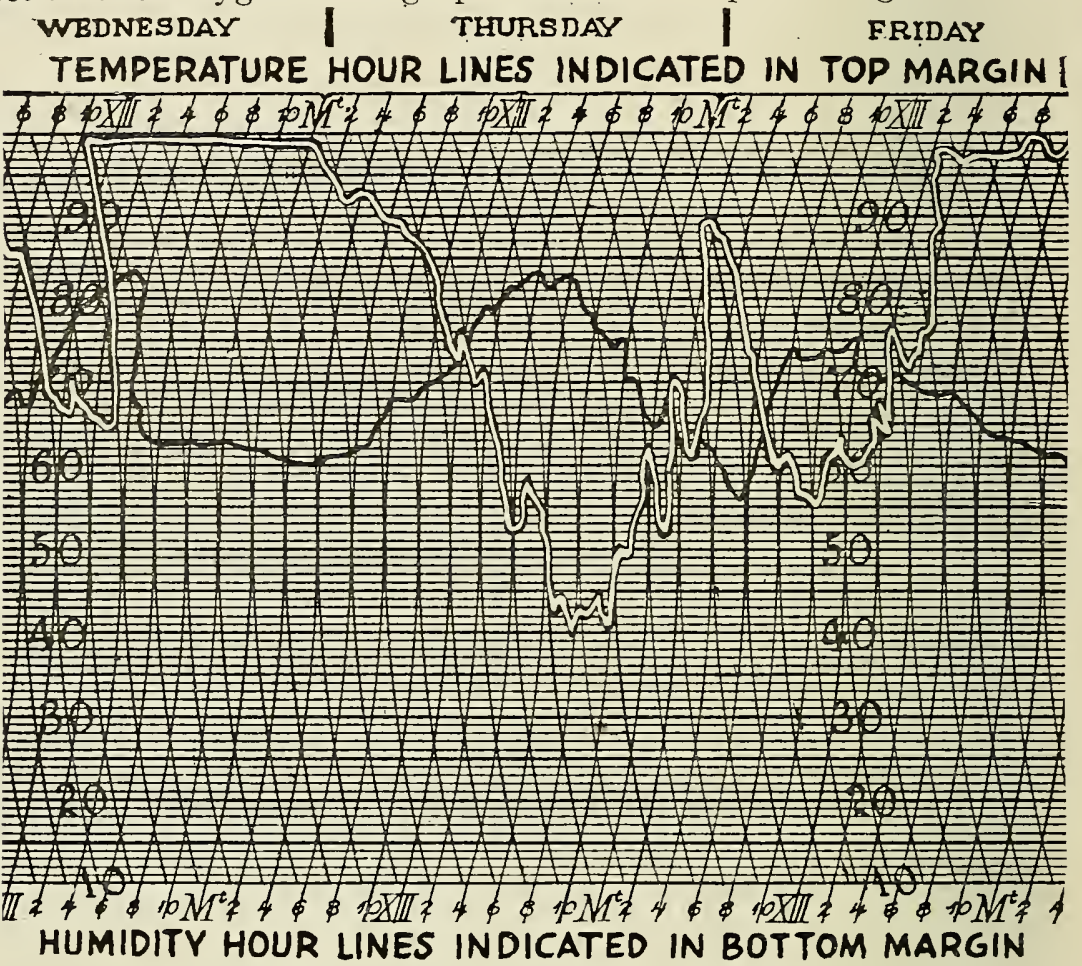

Hygrothermograph Record from June 6th to June 8th, 1917. Double Line is Humidity and Single Line is Temperature.

The data secured previous to 1.915 were of such character as to indicate that sporidia discharge was associated with a fairly well marked drop in humidity, but field observations and experiments conducted since that time warrant the conclusion that no very appreciable decrease is necessary although the effect of temperature upon the humidity requirements is to receive further detailed study. Temperature is a very vital factor, and from all records thus far available it would seem that the optimum temperature for natural infection of apple leaves with rust is around $65^{\circ} \mathrm{F}$. Infection may often take place when the temperature is below $60^{\circ} \mathrm{F}$. but there is not likely to be a severe natural infection when it is below $55^{\circ} \mathrm{F}$. and very few sporidia are discharged at a temperature of $50^{\circ} \mathrm{F}$. or below.

The author firmly believes that one of the most important problems in modern plant pathology is to learn the exact temperature and moisture interrelationships associated with the spread and development of various diseases. This is particularly true of the apple rust, 
and some such studies of this disease under controlled conditions are now in progress.

Wind direction and velocity are of considerable importance in the case of wind-borne infective material such as the sporidia of this rust.

It should be noted that there may be a very heavy discharge of sporidia without any general infection of apple foliage or fruit taking place, even though abundant susceptible material is close at hand. The same sort of occurrence is doubtless true of other diseases and, makes it essential to distinguish between the discharge or spread of infectious material and infection itself.

The rust infection which occurred on May 4th to 5th, 1914, is worthy of a second thought since it took place during the night under conditions which would have proved very confusing without careful and exact records.

The stage of development of apple foliage is an important factor influencing infection and it will be considered in more detail under the heading of Immunity in Apple Leaves.

The relative locations of orchards and cedar trees form an important factor in connection with rust epidemics. Obviously a cedar tree has much better opportunity for effective dispersal of rust sporidia when it is located on ground higher than that of nearby apple orchards. The sporidia act much like grains of pollen or particles of dust when they are in the air. The distance to which they may be carried is largely dependent upon the wind, but the comparative elevation from which they start and objects which may intercept them must also be considered. McCarthy (1893, p. 86) states that mature spores may be carried four miles in an unusually high wind. Thaxter $(1891, \mathrm{p} .3)$ says, "Although it has been shown that infection from cedars may take place at a distance of eight miles, the virulence of the disease is, of course, proportionate to the proximity of the cedars." It is quite probable that freshly discharged sporida are carried as far as eight miles in a high wind, but rarely, if ever, would other conditions be so favorable as to produce an infection of economic importance at that distance from the cedars.

\section{IMMUNITY IN APPLE LEAVES}

The gradual development of resistance or immunity in the leaves of susceptible apple varieties is very striking and extremely important. Stewart (1910, p. 317) says, "The spring of 1903 was very dry at Riverhead, Long Island. There was no precipitation of any importance between April 16th and June 8th. As a consequence, there was no opportunity for the infection of apple leaves until June 8th and 9th on which dates there were heavy showers and the cedar apples became swollen into yellow gelatinous masses of unusually large size. Very little rust occurred on the leaves that year." Evidently most of the leaves had become immune when that infection occurred.

Reed $(1914$, p. 15) gives some records in regard to the development of immunity. 
There were two rust infections in 1911. We do not know the exact dates when they occurred, but one was probably just as the first blossoms were about to open and the other not until the latter part of May. 'The terminal growth on York Imperial twigs during that season commonly showed nine large leaves. The first three and last three leaves on such a growth were rust infected, while between them were three leaves free from rust. This was noticeable, and was commented upon by many orchard men. The fourth, fifth, and sixth leaves must have been immune at the time that the three youngest leaves were infected.

The same thing is clearly shown in Table VI. At the time when the important infection took place in 1913 the first three to five large leaves had become immune. Table XX indicates this in relation to the June 4th and 5th infection of 1914 . During 1914 records were kept on several twigs showing the exact date when each leaf finally opened out from the bud. From the data for this season it seemed that a leaf might be immune ten days after unfolding, but the records covering that point were not very extensive or complete.

During the season of 1915 records were kept on a large number of leaves showing the exact date when they opened out from the bud. Numerous field inoculations were made on these leaves of known age but the records were lost with the notebook previously mentioned. The natural infections occurred at such times as to produce rust on practically every York Imperial apple leaf except a few which opened out in the latter half of May. It would seem from Table VII that the first two or three leaves were practically immune when the infection of May 12th took place. They were about 17 days old at that time.

A large number of field and laboratory inoculations were made upon leaves of known age in 1916, and the results for that season indicated that the first and second large leaves from a terminal bud became immune in from 15 to 16 days, the third and fourth in from 17 to 18 days, and the fifth and sixth in from 20 to 21 days. The progressively longer period of susceptibility of the later leaves is of interest and should be compared with similar field data for 191\%. The natural infection in 1916 occurred on May 23rd and the immunity of the first five leaves on terminal growths may be noted in Table VII. The average age of the fifth leaf on terminals was twenty days at the time of this infection.

Similar field experiments in 1917 upset any tentative conclusion that the first leaves necessarily become immune in less time than the later leaves. An average of the records shows that the first large leaf was immune in 20 days, the second in from 23 to 25 days. the third in from 27 to 28 days, the fourth in from 25 to 26 days, the fifth in from 21 to 22 days, the sixth in from 19 to 21 days and the seventh in from 18 to 20 days. These figures show very clearly that the age alone, or age in connection with relative location of the leaf may not be depended upon to indicate immunity or susceptibility. This variation in the period of susceptibility for the season of $191 \%$ is undoubtedly due to the very unfavorable weather which inhibited normal development 
of the apple foliage. The first natural infection occurred during the night of May 2\%th-28th and at that time the fourth leaf on terminal growths was about 27 days old. The practical immunity of these four leaves may be noted from Table VII.

Some experiments conducted under greenhouse conditions in 1917 indicated that the leaves were susceptible for from fifteen to twentyfour days after unrolling. The first leaves to come out showed some tendency to become immune in a shorter period of time, but there was considerable evidence of variation which may have been due to imperfect inoculations in some cases.

The study of leaf age as related to susceptibility led to a consideration of leaf growth as a factor. During the season of 1915 a Ganong space marker was used in an effort to secure some data along this line but the results were hopelessly unsatisfactory. In 1916 a few direct leaf prints were made on lantern slide plates and a few on blue print paper. The blue print paper was found to be fairly useful for this work in the field and in 1917 successive prints were made from 32 York Imperial apple leaves. The first prints were made on May 18th and 19th, while the leaves were still growing, and the final set was made on June 3rd after all except two or three of them had completed their growth. The prints were secured from leaves of different ages, the oldest being the third large leaf and the youngest the eighth large leaf from a terminal bud. It might be noted in passing that trouble was frequently encountered because of irregular growth which resulted in folding or wrinkling of the leaf surface when one attempted to lay it out flat on the paper. Accurate measurements of growth seem practically impossible in the case of such leaves and it appears difficult to recognize a leaf which may cause trouble until its growth is very well advanced.

Inoculations were made on twenty-six of these leaves at one time or another while their growth rate was being watched. Sixteen of these leaves showed growth after they were inoculated and of this number all but one was infected. Nine of the leaves showed no growth after inoculation and only two of this group were infected. There was doubt in regard to the growth of one inoculated leaf, but it became infected. These experiments are insufficient to warrant any general conclusions, but they indicate that susceptibility is very closely associated with leaf growth.

It was thought, and is still believed, that this acquired immunity in York Imperial leaves is due primarily to a change in the materials available as food for the early nutrition of the fungus; and secondarily to certain changes in the thickness and composition of cell walls, leaf covering, etc., which might be classed as physical.

During the spring of 1916 records were kept showing the age of each leaf in 88 typical terminal twig growths on 22 trees which were selected to represent about 40 trees in one corner of a ten-year-old York Imperial orchard. This orchard was so situated that it received little, if any, natural rust infection. The third, fourth, and fifth large leaves from a terminal bud were selected to be taken for chemical 
analysis, and collections were made every second or third day from the time these leaves were 8 days old until they were 25 days old. Triplicate samples of 100 grams each were taken on each date. Each 100 grams of leaves was collected and weighed as rapidly as possible and placed at once in a glass jar containing $700 \mathrm{cc}$. of 95 percent alcohol. The samples were collected at approximately the same hour each day and notes were taken as to the weather conditions during the day. Inoculations in triplicate were made on similar twigs every second or third day during this period in order to have data showing when the leaves became immune.

Preliminary analyses have been made of some of this material but the data is insufficient to warrant publication at this time. There are, as might be expected, certain well marked changes in nitrogen and carbohydrate content at various stages of growth, but any data which might be of value regarding the development of immunity can only be secured after making a large number of analyses and correlating the results with various factors such as age, growth, and weather. More extensive analyses are contemplated just as soon as adequate facilities are available.

From the evidence submitted it may not be claimed that there is yet any clear cut evidence as to the exact factors or combinations of factors which result in the development of immunity in York Imperial apple leaves, but it is believed that some suggestive openings have been made for further work in that connection.

The difference in susceptibility of apple varieties has been recognized for some time. Halstead (1889, p. 380) speaks of it as a probability but not established by sufficient records, while Stewart and Carver $(1896$, p. 538) conducted some experiments which showed that there was a great difference in susceptibility.

Since that time many lists have been published giving data on the susceptibility or resistance of different varieties as they have been observed in various sections of the country. Table I gives some of the more important varieties and their susceptibility as listed by different states. Four signs are used to indicate varying degrees of susceptibility or immunity: 0 indicates immune, 1 indicates resistant, 2 indicates moderately susceptible, 3 indicates susceptible. 
Table I.-Susceptibility of Apple Varieties to Rust as Reported by Different States

\begin{tabular}{|c|c|c|c|c|c|c|c|c|c|c|c|c|c|c|c|}
\hline VA. & $\mid$ & & & & & & & 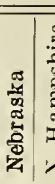 & 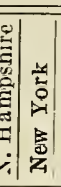 & & & 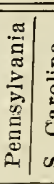 & & & \\
\hline rkansas Black --_-_- & & & 0 & & 1 & & & & & 1 & & & & & \\
\hline Baldwin & & $1 j$ & & & & $|1|$ & & & 1 & & 1 & & & & \\
\hline Ben Davis - & & & $1 \mid$ & 3 & & $1 \mid$ & & 1 & & & 1 & & & \begin{tabular}{l|l}
$3|2|$ & 2
\end{tabular} & \\
\hline 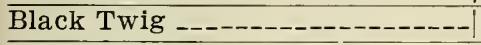 & 11 & & 0 & & & & & & & & & & & & \\
\hline A & & & 3 & & & & & & & 3 & & & & & \\
\hline se $-----0-0-1$ & & & & 1 & 3 & & & & & & & & & & \\
\hline 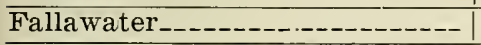 & & & 3 & & & & & & & 3 & & & & & \\
\hline$-\ldots$ & 2 & 1 & \begin{tabular}{l|l}
3 & 1 \\
3
\end{tabular} & 1] 3 & 1 & & & 1 & & & & & $3 \mid 1$ & & \\
\hline athan & $|3|$ & & & $3 \mid 1$ & & & & $3 \mid$ & & & & 3 & & & \\
\hline aiden Blush -. & $|1|$ & & $|1|$ & & 3 & & & 1 & & & & & & $1 \mid$ & \\
\hline ern Spy - - - & & & & & & & & & & & & & & & \\
\hline reening _---------------| & & $1 !$ & & & & & & & & & & & & 2 & \\
\hline ---------- & $|3|$ & & $0 \mid$ & & & & & $3 \mid$ & & $3 \mid$ & & & 3 & & \\
\hline rachan & 1 & & $0 \mid$ & & & 1 & & 1 & & & 1 & & & & \\
\hline - n- & $3 \mid$ & & $0 \mid 3$ & & 3 & & & & & $3 \mid$ & & $3 \mid$ & & $3 \mid$ & \\
\hline 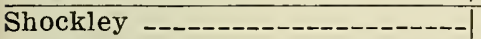 & 3 & & & & & & & & & $3 !$ & & & $3 \mid$ & & \\
\hline 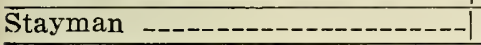 & & & $0 \mid$ & & & & & 1 & & 1) & & & & $0 \mid$ & \\
\hline 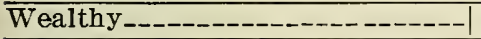 & & $3 \mid$ & 3 & \begin{tabular}{l|l}
3 & 3 \\
\end{tabular} & $|3|$ & $|3|$ & 3 ! & & 31 & & $|3|$ & & & & \\
\hline nesap -- -- & $1 \mid$ & & 1 & & 1 & & & 1| & & 1) & & & & $|40|$ & \\
\hline w Transparent___- & & & $0 \mid$ & & & 1 & & $1 \mid$ & & & 1 & & & $0 \mid$ & \\
\hline ork Imperial & $2 !$ & & & & & & & & & & & 3 & & $3 \mid$ & \\
\hline
\end{tabular}

Some varieties are listed as susceptible in one state and resistant in another. While there is undoubtedly some variation due to the difference in location, we are inclined to think that the judgment of the individual as to what constitutes resistance or susceptibility is a more important factor. Observations made upon single trees are sometimes misleading, since noticeable variation is often apparent among trees of the same variety. Different periods of rust infection may also give rise to confusing data, because the leaves of one variety may expand more quickly or have a shorter period of susceptibility than the leaves of another variety.

From the data at hand the following list is given for West Virginia:

Susceptible

York Imperial

Rome

Wealthy

Jonathan

\section{Moderately} Susceptible

Ben Davis

N. W. Greening
Resistant

Black Twig

Grimes

Maiden Blush
Baldwin

Winesap

Ark. Black

Stayman

Yellow Transparent 


\section{PHYSIOLOGICAL EFFECT OF RUST ON APPLE}

Early in the work on this disease a question was raised as to the effect of rust on the general health of an apple tree. It was believed that the injurious effects of a serious rust infection would persist during the season following such an outbreak. There was very little evidence at hand in regard to this and it appeared difficult to secure since the infection is so general that all the trees of any one variety in a given section are liable to show nearly the same amount of disease.

Two orchards were finally found which may serve for some general comparisons. These orchards were less than two miles apart and will be designated as No. 1 and No. 2. The trees chosen for comparison were of the same variety, York Imperial, and the same age, 11 years. Orchard No. 1 had received good care, and happened to be so situated as not to have suffered from very severe infections of rust. One of the trees in this orchard is shown by Plate IX, Fig. 3. This tree was growing under soil and drainage conditions as nearly comparable as possible with those of orchard No. 2. Orchard No. 2 had received what might be called fair cultural attention. It had been plowed, fertilized, and sprayed, but not quite so systematically and carefully as orchard No.1. This orchard was not over ten or fifteen acres in area and there were cedar trees within two rods of it on every side. There was a number of large cedar trees, twenty to thirty feet high, within ten to twenty rods of the orchard, and many small cedars on all sides. In 1913, when particular note was first taken of this orchard, the cedar trees around it were practically loaded down with rust galls. A typical York Imperial tree in orchard No. 2 is shown by Plate IX, Fig. 4. There were about equal numbers of York Imperial and of Ben Davis apple trees in the last mentioned orchard. The trees of both varieties were the same age and had received the same care, but the owner reported that the York Imperial trees had not borne more than an average of three apples per tree while the Ben Davis trees had borne an average of three barrels per tree. The Ben Davis trees, right beside the York Imperials, had made good growth. They were at least two-thirds larger than the York Imperial trees and appeared very healthy.

It seems safe to conclude that the lack of development of the York Imperial apple trees in orchard No. 2 was largely the effect of the serious rust infection occurring each year.

Another case which seems worthy of mention is that of some trees showing a far more severe infection on one side than on the other. This one-sided infection took place in 1912. The trees were York Imperials, about 12 years of age, in rows along the top of a ridge. There was a considerable number of cedars in the vicinity of 


\section{PLATE VI}

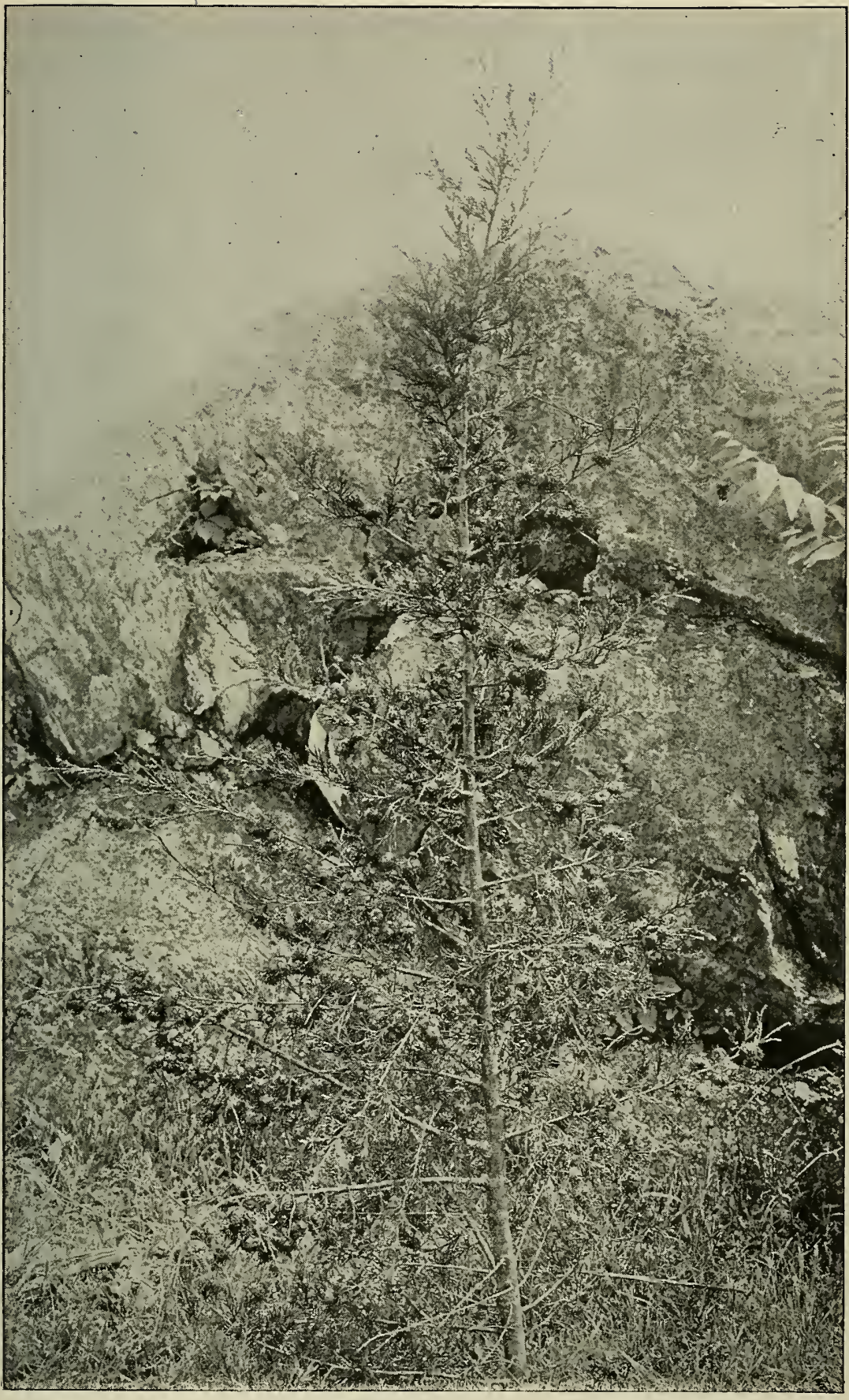


the orchard, and a large grove of them a little way down on one slope of the ridge. A strong wind was blowing from this grove into the orchard at the time of infection, and the effects of the disease appeared to be at least twice as severe on the side toward the cedar grove as on the other side. On the side where infection was greater, the apples were not more than two-thirds as large as those on the other side (Plate VII, Fig. 1).

In the spring of 1913 this orchard was visited and it was found that the trees which showed the one-sided rust infection in 1912 were not blooming at all on the side where the disease was so severe, while there was a very fair amount of bloom on the other side. No good photographs of the trees were secured at that time. A late spring frost destroyed all of the young fruit which had set on these trees, and it was believed that they would entirely recover to their normal condition by the following spring.

The orchard was visited again the spring of 1914, and evidences of the one-sided rust infection were still visible in the first four or five rows of apple trees extending along the top of the ridge. Quite a bit of individual variation in the trees could be noted, but there was a very clear difference between the two sides. The bloom was slight or scattering on the side where rust infection had been severe, and was very profuse on the other side (Plate VII, Fig. 2).

The trees in question may have suffered from one-sided rust infections previous to 1912, but evidence from observation or from the development of the trees does not indicate that such was a regular, or even frequent, occurrence. It should be noted that all cedars in the immediate vicinity of this orchard were destroyed during the winter of 1912-13 and that the radius of cedar-free territory was extended during the winter of 1913-14. Whatever rust infection took place in this orchard during the 1913 and 1914 seasons was very uniformily distributed and can have had but little effect upon the one-sided fruit production of the trees in question.

Spraying experiments, conducted in 1912*, prevented serious rust infection on portions of certain York Imperial trees in one orchard. The only York Imperial bloom observed in this orchard in 1913 was on the parts of trees where rust had been controlled the previous

* The experiments in 1912 were conducted in an orchard owned by D. Gold Miller at Gerrardstown. The experiments in 1913 were conducted in the orchards of Hon. George M. Bowers and B. 'Frank Mish at Inwood. The experiments in 1914-17 were conducted in the orchard of Dr. A. P. Thompson at Sum.mit Point. Acknowledgment is made these gentlemen for their courtesy in connection with this work.

\section{PLATE VII}

Fig. 1.-Apples from trees with one-side rust infection in 1912. The two at the right were largest on side which showed least infection, while the two at the left were largest on badly infected side. Collected about August 1, 1912.

Fig. 2.-Apple tree which suffered from one-sided rust infection in 1912. Picture taken May 3, 1914. Note bloom on side which produced large apples like those shown at right, above, in 1912. 


\section{PLATE VII}

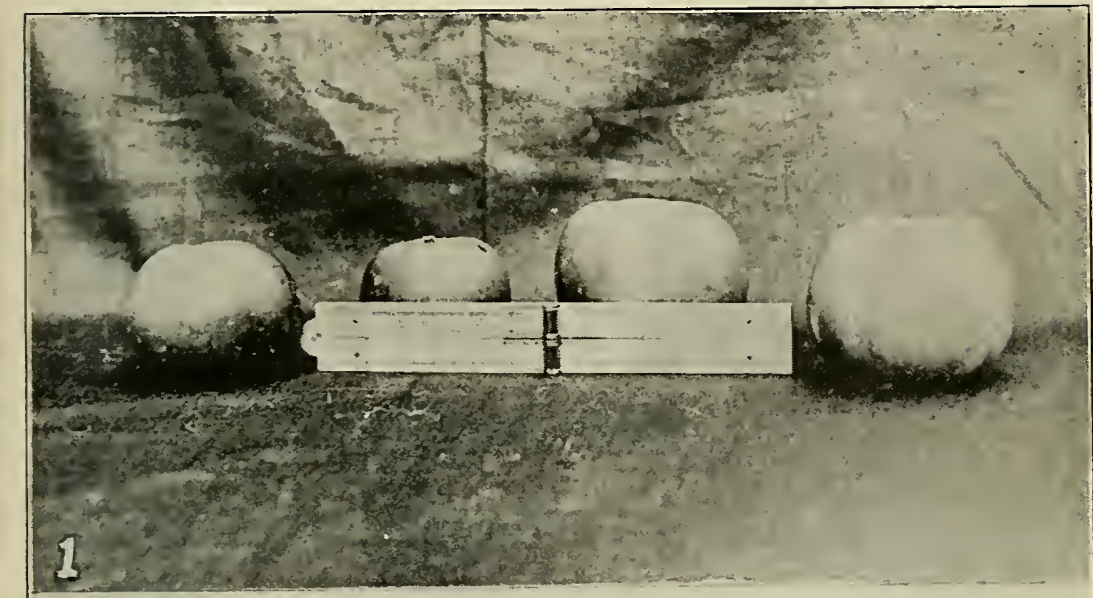

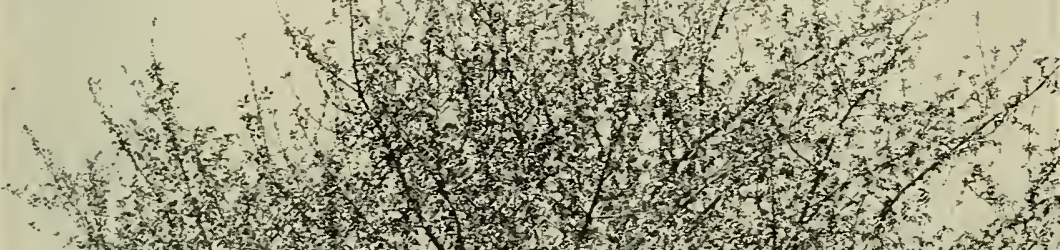

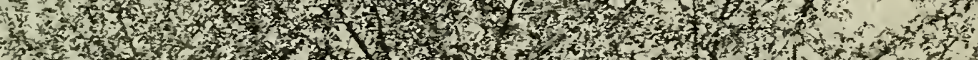
,

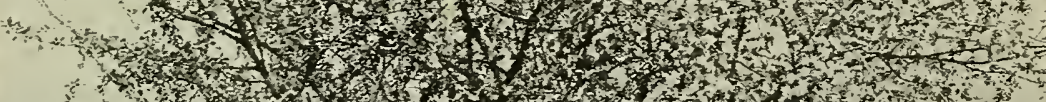

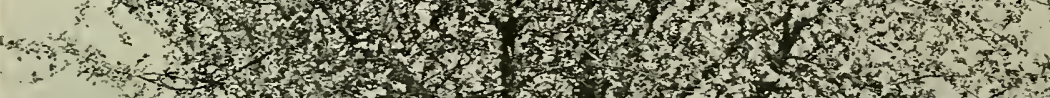

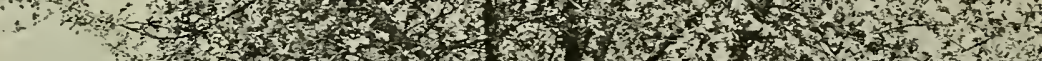

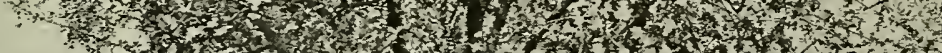

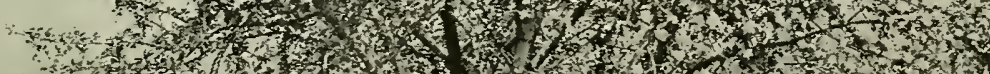

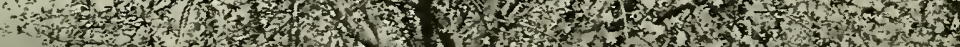

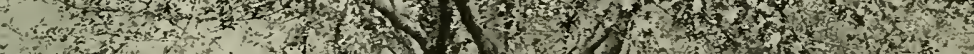

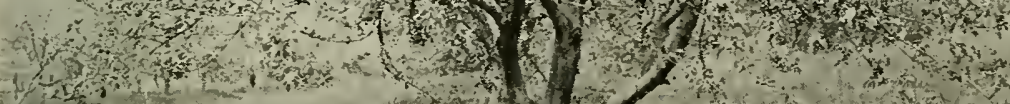

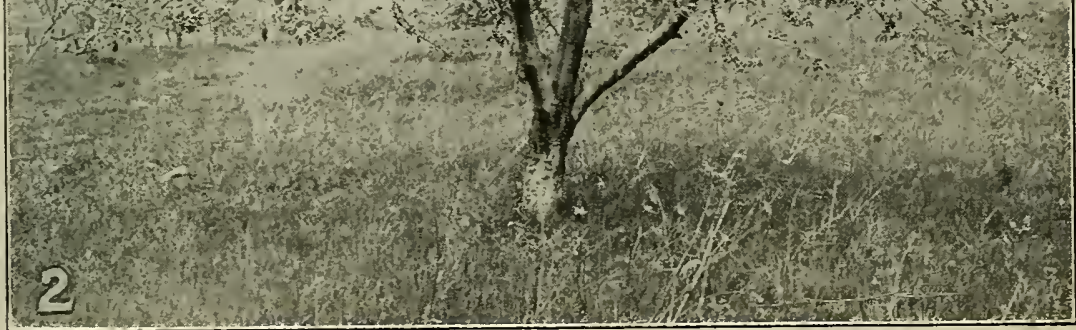


season. It was also observed in 1913 that these portions of trees retained their foliage longer than unsprayed portions of the same tree and longer than any unsprayed trees in the orchard. Their condition was not noted in 1914 .

Spraying experiments were again conducted in 1913 but practically all of the young fruits were destroyed by late frosts and general rust infection was not so severe as in 1912. The number of leaves showing rust spots and the number not so diseased were determined on one or more twigs of each tree used in these experiments. 'The count was made about June 10 th and the two small leaves which unfolcled first were removed before counting. The leaves were again counted during the first week in October, and from this count it was possible to determine the number of rusted leaves which had fallen as compared with the number of rust-free ones which had fallen. The results are briefly summarized in the following table:

\section{TABLE II.-Leaf Fall as Affected by Rust in 1913}

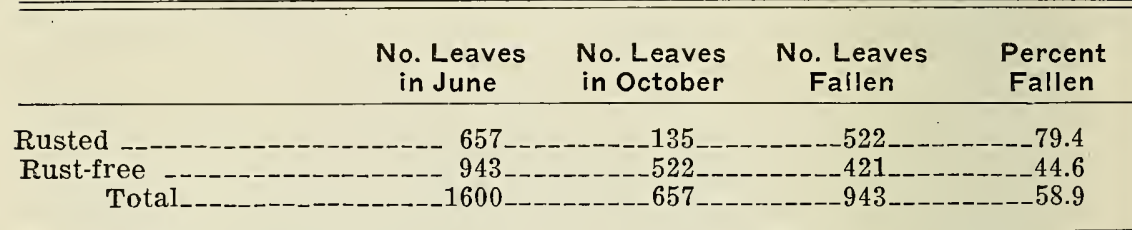

This table includes counts from ten trees chosen at random from among those upon which rust had not been controlled. Detailed tables might be given but they would show little more, and the data for 1914 will be of more interest and value along this line. Reference to Table VI will show the number and distribution of rust spots on unsprayed York Imperial leaves in 1913 for comparison with figures for leaf fall. The effect of rust control upon leaf fall in 1913 is also indicated by Plate VIII, Figs. 1 and 2.

During the season of 1914 this phase of the work was enlarged to include the location of each leaf in regard to order of opening from bud, and the number of rust spots on each leaf as well as the number of leaves. The two small, oldest leaves were removed before counts were made. These detailed field counts were made on twenty-five trees, and included about 320 leaf clusters, of which one-half were terminal growths of twigs. Ten of the trees were unsprayed, five had been sprayed with lime-sulphur, five with Bordeaux mixture, and

\section{PLATE VIII}

Fig. 1.-York Imperial apple tree upon which' rust was controlled by spraying in 1913.

Fig. 2.-York Imperial apple tree upon which rust was not controlled in 1913. This tree is just adjacent to the one shown in Fig. 1. 


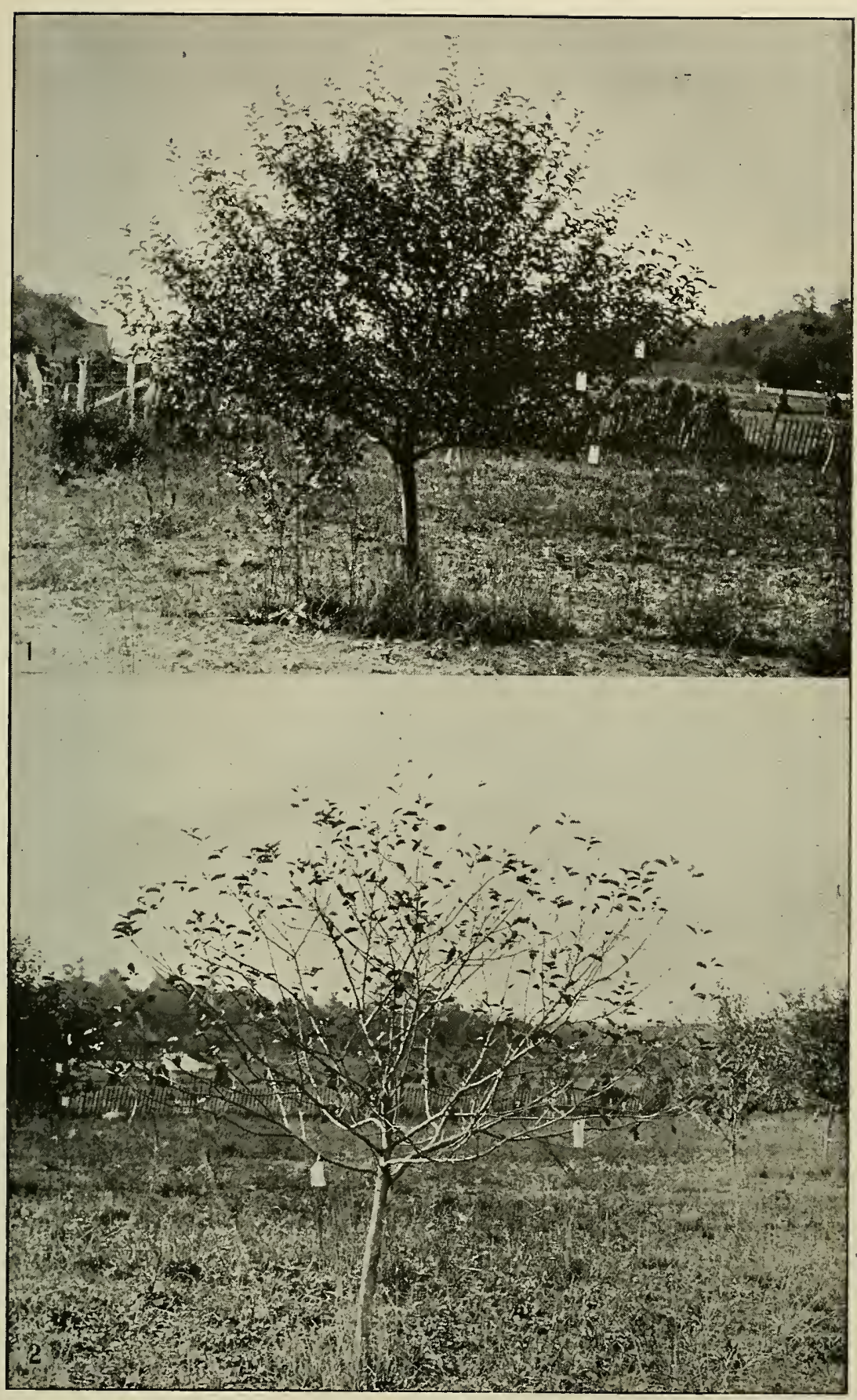


five with atomic sulphur. The rust was quite well controlled on the sprayed trees.

A sample page of the records on these leaves is shown:

TREE No. 323-TWIG No. 2

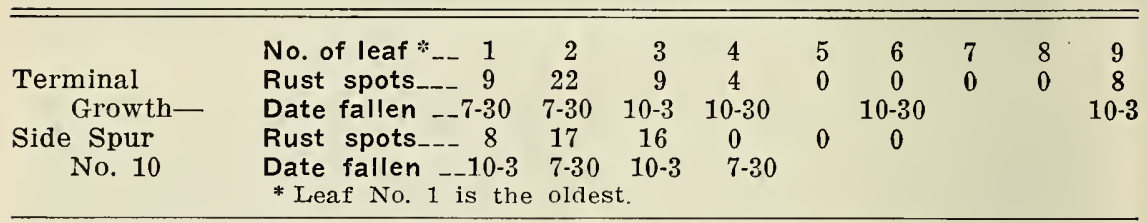

The data from these records have been carefully tabulated and are given in condensed form as Table III. This table is arranged to show the number of leaves having from one to four rust spots, the number having from five to nine rust spots, etc. It also gives the number of such leaves which had fallen between specified dates. The first counts were made July 3 rd to 9 th, and some of the badly rusted leaves had fallen at that time. Counts were again made July 28-30, August 27-30, and October 2-5.

\section{TABLE III.-Leaf Fall as Influenced by Number of Rust Spots per Leaf in 1914}

\begin{tabular}{|c|c|c|c|c|c|c|c|c|c|}
\hline \multirow{3}{*}{$\begin{array}{l}\text { Number of } \\
\text { Rust Spots } \\
\text { Per Leaf }\end{array}$} & \multirow{3}{*}{$\begin{array}{l}\text { Number: } \\
\text { of } \\
\text { Leaves? }\end{array}$} & \multicolumn{6}{|c|}{ Number of Leaves Fallen by Periods } & \multirow{2}{*}{\multicolumn{2}{|c|}{$\begin{array}{l}\text { Total Fallen } \\
\text { July } 6 \text { th to } 0 \text { ct. } 4 \text { th }\end{array}$}} \\
\hline & & \multicolumn{2}{|c|}{ July 6 th to July 29 th } & \multicolumn{2}{|c|}{ July 29th to Aug. 29th } & \multicolumn{2}{|c|}{ Aug. 29th to 0ct. 4th } & & \\
\hline & & No. & Percent & No. & Percent & No. & Percent & No. & Percent \\
\hline None & 832 & 23 & 2. & 9 & 1. & 45 & 5.4 & 77 & 9.2 \\
\hline 1 to 4 inc. & 560 & 23 & 4.1 & 12 & 2. & 9 & 16. & 125 & 22.2 \\
\hline 5 to 9 inc. & 231 & 23 & 10.0 & 16 & 6.9 & 66 & 28.6 & 105 & 45.5 \\
\hline 10 to 14 inc. & 126 & 20 & 15. & 17 & 13.5 & 50 & 39.6 & 87 & 69.0 \\
\hline 15 to 26 inc. & 264 & 80 & 30. & 54 & 20.5 & 86 & 32.5 & 220 & 83.3 \\
\hline 28 to 60 inc... & 184 & 65 & 35.3 & 75 & 40.8 & 35 & 19.0 & 175 & 95.1 \\
\hline Over 60 & 23 & 13 & 56.5 & 7 & 30.5 & 2 & 8.7 & 22 & 95.7 \\
\hline
\end{tabular}

The above data show that rate of leaf fall previous to October 1, 1914, was very closely proportional to the number of rust spots per leaf.

Additional tables might be given to show the results from sprayed and unsprayed trees but they would indicate little that is not already shown in Table III. The sprayed trees, of course, have fewer rusted leaves and comparatively more leaves with a small number of spots per leaf, but the percentage leaf fall seemed to be fairly constant for leaves showing a certain number of rust spots.

One other condensed table may well be included to show the effect of rust on foliage retention during the season of 1914. This table includes records from 58 trees and about 300 twigs. The data already given for 1914 are included. 
TABLE IV.-Leaf Fall as Affected by Rust in 1914

No. Trees Included

Treatment

No. Leaves Counted

Percent Leaves Rusted

No. of Spots Per Rusted Leaf.

Percent Leaves Fallen Before

October 4
18 atomic sulphur 4553

63.

4.8

35.9 \begin{tabular}{c|c|c}
18 & 23 & 9 \\
Bordeaux & lime-sulphur & check
\end{tabular} 4257

32.3

2.5

26.7
5493

31.2

2.9

2030

86.7

17.5

72.6

It should be noted that this table shows the total leaf fall between July 6 th and October 4 th.

It may be noted in Table VI that leaves 1 to 4 were the ones most severely infected this season. These leaves, being older, might have had a tendency to fall earlier and it was decided that similar records might well be secured covering several seasons, since the number and distribution of rust spots would vary more or less every year.

Leaf fall data for 1915 are given in Table V. 'The relationship between number of spots and rate of leaf fall is not quite so uniform for this season. A glance at Table VII will show that practically every leaf was infected except for an occasional terminal, while the greatest number of rust spots is found on leaves 4 to $\%$.

TABLE V.-Leaf Fall as Influenced by Number of Rust Spots per Leaf in 1915

\begin{tabular}{|c|c|c|c|c|c|c|c|c|c|c|c|}
\hline \multirow{3}{*}{$\begin{array}{l}\text { Number } \\
\text { Rust Spots } \\
\text { Per Leaf }\end{array}$} & \multirow{3}{*}{$\begin{array}{l}\text { Number } \\
\text { Leaves }\end{array}$} & \multicolumn{8}{|c|}{ Number of Leaves Fallen by Periods } & \multirow{2}{*}{\multicolumn{2}{|c|}{$\begin{array}{l}\text { Total Fallen } \\
\text { June } 12 \text { to } \\
\text { Sept. } 20\end{array}$}} \\
\hline & & \multicolumn{2}{|c|}{ June 12 to $A$ ug. 11} & \multicolumn{2}{|c|}{ Aug. 11 to Aug. 20} & \multicolumn{4}{|c|}{ Aug. 20 to Sept. 1 Sept. 1 to Sept. 20} & & \\
\hline & & No. & Percent & No. & Percent & No. & Percent & No. & Percent & No. & Percent \\
\hline None & 67 & 0 & 0 & 1 & 1.5 & 0 & 0 & 1 & 1.5 & 2 & 3.0 \\
\hline 4 inc. & 163 & 2 & 1.2 & 3 & 1.8 & 1 & 0.6 & 31 & 19.0 & 37 & 22.6 \\
\hline 5 to 9 inc. & 271 & 0 & 0 & 12 & 4.4 & 18 & 6.7 & 113 & 41.7 & 143 & 52.8 \\
\hline 10 to 14 inc. & 238 & 4 & 1.7 & 6 & 2.5 & 17 & 7.2 & 115 & 48.3 & 142 & 59.7 \\
\hline 15 to 26 inc. & 271 & 1 & 0.4 & 6 & 2.2 & 18 & 6.7 & 141 & 52.0 & 166 & 61.3 \\
\hline 28 to 60 inc. & 149 & 1 & 0.7 & 9 & 6.0 & 7 & 4.7 & 82 & 55.0 & 99 & 66.4 \\
\hline Over 60 & 445 & 11 & 2.5 & 121 & 27.2 & 109 & 24.5 & 173 & 38.8 & 414 & 93.0 \\
\hline
\end{tabular}




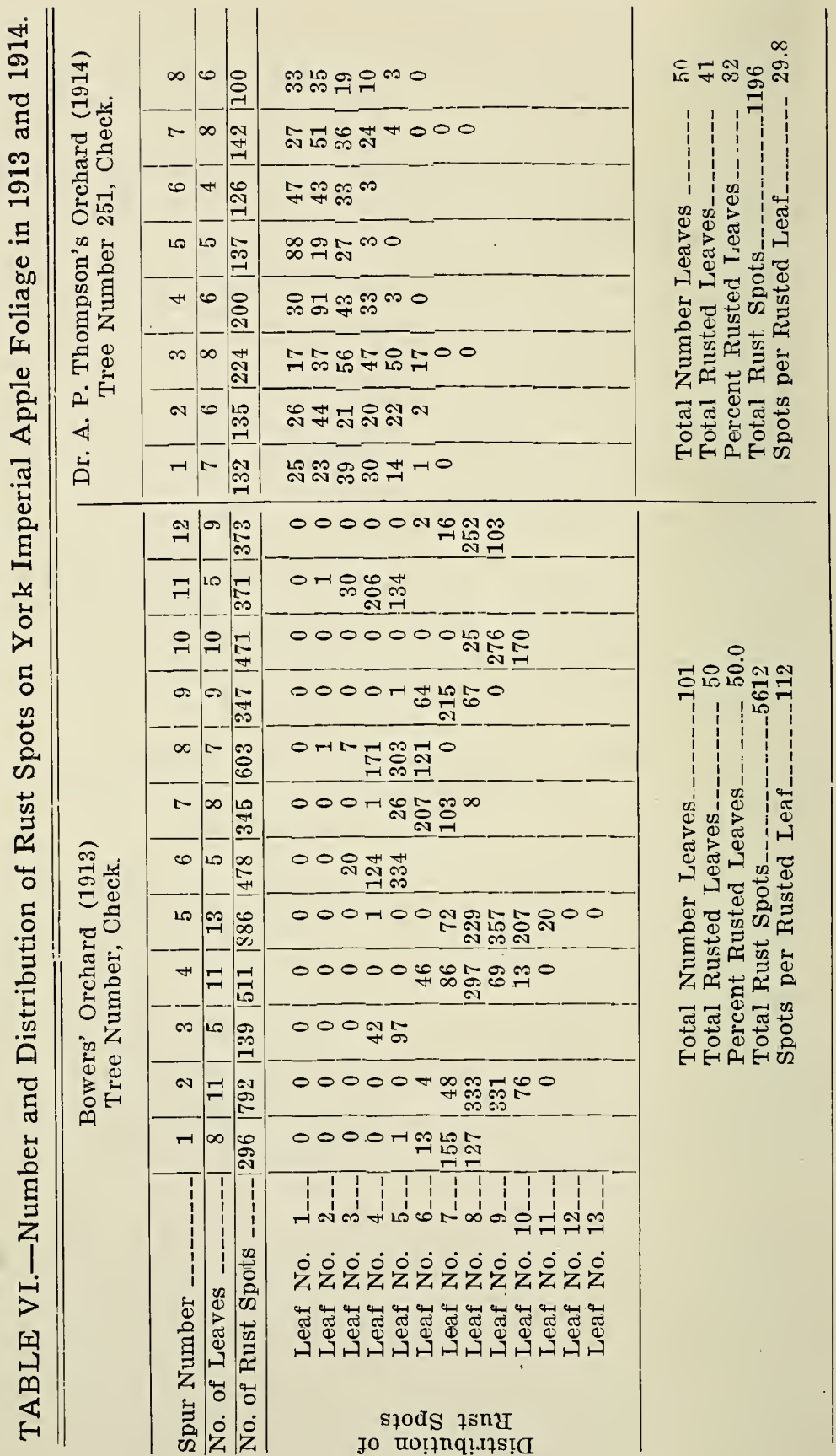




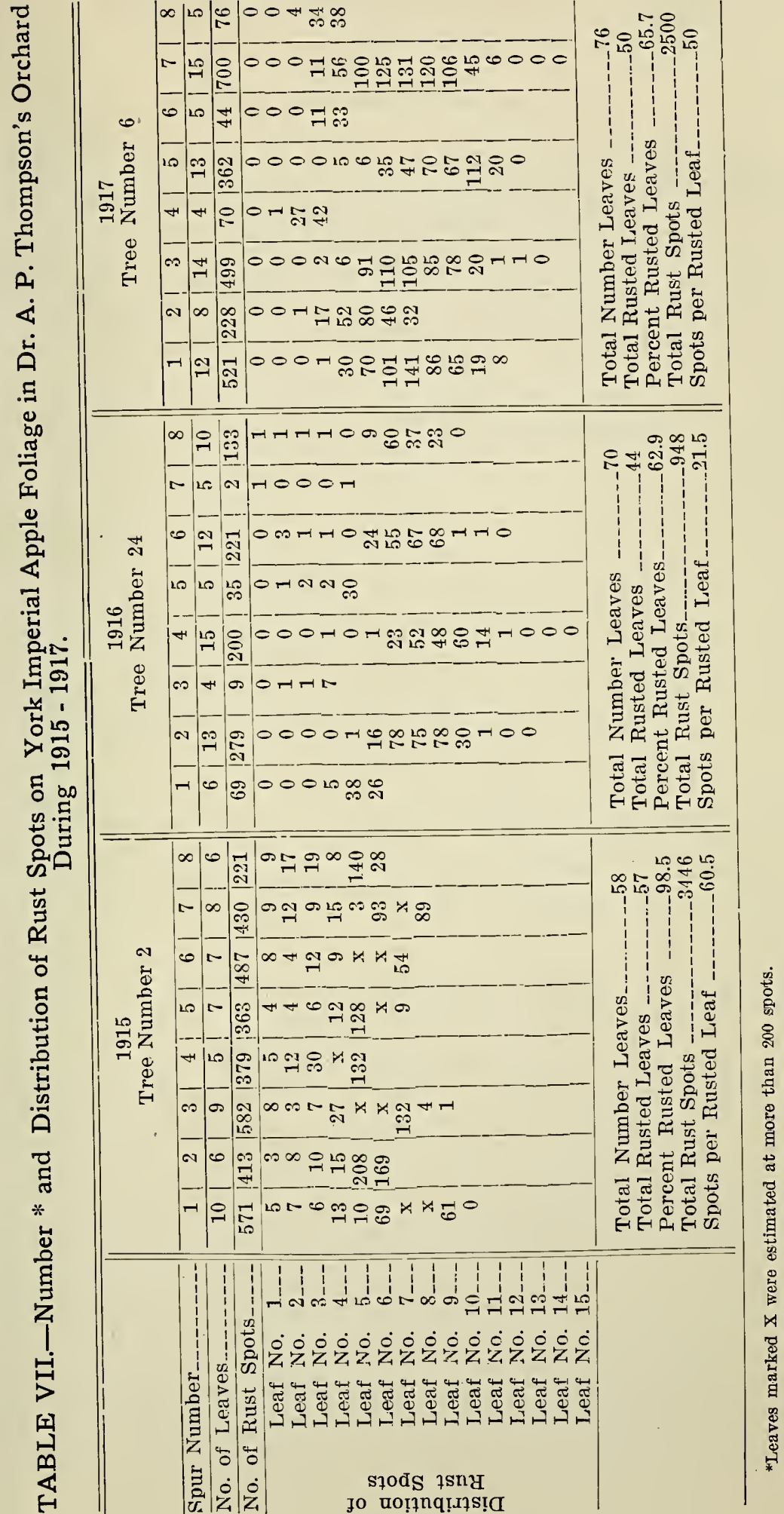


The table for 1916 shows a remarkable cliange in leaf fall ratio. TABLE VIII.-Leaf Fall as Influenced by Number of Rust Spots Per Leaf in 1916.

\begin{tabular}{|c|c|c|c|c|c|c|c|c|c|c|c|}
\hline \multirow{3}{*}{$\begin{array}{c}\text { Number } \\
\text { Rust Spots } \\
\text { Per Leaf }\end{array}$} & \multirow{3}{*}{$\begin{array}{l}\text { Number } \\
\text { Leaves }\end{array}$} & \multicolumn{8}{|c|}{ Number of Leaves Fallen by Periods } & \multirow{2}{*}{\multicolumn{2}{|c|}{$\begin{array}{c}\text { Total Fallen } \\
\text { July } 13 \text { to } \\
\text { Oct. } 2\end{array}$}} \\
\hline & & \multicolumn{2}{|c|}{$\begin{array}{l}\text { July } 13 \text { to } \\
\text { Aug. } 22\end{array}$} & \multicolumn{2}{|c|}{$\begin{array}{l}\text { Aug. } 22 \text { to } \\
\text { Sept. } 4\end{array}$} & \multicolumn{2}{|c|}{$\begin{array}{r}\text { Sept. } 4 \text { to } \\
\text { Sept. } 16\end{array}$} & \multicolumn{2}{|c|}{$\begin{array}{l}\text { Sept. } 16 \text { to } \\
\text { Oct. } 2\end{array}$} & & \\
\hline & & No. & Percent & No. & Percent & No. & Percent & No. & Percent & No. & Percent \\
\hline None & 641 & 29 & 4.5 & 43 & 6.7 & 126 & 19.7 & 179 & 28. & 377 & 58.9 \\
\hline 1 to 4 inc.-- & 735 & 20 & 2.7 & 55 & 7.5 & 115 & 15.6 & 192 & 26.2 & 382 & 52.0 \\
\hline 5 to 9 inc... & 141 & 3 & 2.1 & 6 & 4.3 & 27 & 19.2 & 35 & 24.9 & 71 & 50.5 \\
\hline 10 to 14 inc. & 88 & 0 & 0.0 & 4 & 4.6 & 18 & 20.3 & 32 & 36.4 & 54 & 61.3 \\
\hline 15 to 26 inc. & 159 & 5 & 3.1 & 26 & 16.4 & 51 & 32.1 & 44 & 27.7 & 126 & 79.3 \\
\hline 28 to 60 inc. & 194 & 8 & 4.1 & 36 & 18.5 & 88 & 45.2 & 37 & 19.1 & 169 & 86.9 \\
\hline Over 60 & 111 & 0 & 0.0 & 30 & 27.1 & 59 & 53.1 & 14 & 12.6 & 103 & 92.8 \\
\hline
\end{tabular}

It will be noted that healthy leaves and leaves showing 1 to 4 rust spots actually had a larger percentage dropped than had leaves with 5 to 9 rust spots. This was true throughout the season, from August 22nd to October 2nd, so it was not due to a sudden increase in the number of healthy leaves fallen during the month of September.

The infection in 1916 was comparatively light and the amount of terminal growth was greater than usual as may be seen from Table VII. In this case it would seem as though the relative locations of the leaves had some influence for the majority of the healthy leaves and $\mathrm{ff}$ the leaves having 1 to 4 spots was to be found in leaves 1 to 5 .

The data for 1917 given in Table IX also indicate a very heavy leaf fall for the healthy and slightly infected leaves, but there is an increase in leaf fall for each increase in number of rust spots.

TABLE IX.-Leaf Fall as Influenced by Number of Rust Spots Per Leaf in 1917.

\begin{tabular}{|c|c|c|c|c|c|c|c|c|c|c|c|}
\hline \multirow{3}{*}{$\begin{array}{l}\text { Number } \\
\text { Rust Spots } \\
\text { Per Leaf }\end{array}$} & \multirow{3}{*}{$\begin{array}{l}\text { Number } \\
\text { Leaves }\end{array}$} & \multicolumn{8}{|c|}{ Number of Leaves Fallen by Periods } & \multirow{2}{*}{\multicolumn{2}{|c|}{$\begin{array}{l}\text { Total Fallen } \\
\text { July } 13 \text { to } \\
\text { Oct. } 1\end{array}$}} \\
\hline & & \multicolumn{2}{|c|}{$\begin{array}{c}\text { July } 13 \text { to } \\
\text { Aug. } 1 \\
\end{array}$} & \multicolumn{2}{|c|}{$\begin{array}{l}\text { Aug. } 1 \text { to } \\
\text { Sept. }{ }^{1}\end{array}$} & \multicolumn{2}{|c|}{$\begin{array}{l}\text { Sept. } 1 \text { to } \\
\text { Sept. } 15\end{array}$} & \multicolumn{2}{|c|}{$\begin{array}{c}\text { Sept. } 15 \text { to } \\
\text { Oct. } 1\end{array}$} & & \\
\hline & & No. & Percent & No. & Percent & No. & Percent & No. & Percent & No. & Percent \\
\hline None & $53 \xi$ & 0 & 0 & 2 & 0.4 & 4 & 0.7 & 285 & 53. & |291 & 54.1 \\
\hline 4 inc. - & 138 & 0 & 0 & 0 & 0 & 4 & 2 & 74 & 53.7 & 78 & 56.6 \\
\hline 5 to 9 inc... & 81 & 0 & 0 & 2 & 2.5 & 8 & 9.9 & 42 & 51.8 & 52 & 64.2 \\
\hline 10 to 14 inc. & 38 & 0 & 0 & 1 & 2. & 13 & 34. & 17 & 44.6 & 31 & 81.2 \\
\hline 15 to 26 in & 81 & 0 & 0 & 3 & 3.7 & 47 & 58. & 17 & 21.0 & 67 & 82.7 \\
\hline 28 to 60 in & 219 & 0 & 0 & 92 & 42.0 & 121 & 55.2 & 4 & 1.8 & 217 & 99.0 \\
\hline Over 60 & 228 & 61 & 26.8 & 153 & 67.1 & 14 & 6.1 & 0 & 0 & 228 & 100.0 \\
\hline
\end{tabular}

By taking September 15th as the final date in this table the ratio of leaf fall to rust spots is very uniform, and it is evident that natural defoliation was taking place rapidly during the latter part of Septem- 
ber. As indicated in Table VII, the percentage of rusted leaves in 1917 was very slightly greater than in 1916 while the number of rust spots per leaf was nearly two and one half times as great in $191 \%$.

The leaf fall data for 1916 are rather difficult to explain. The records for the seasons 1914-191\% were all secured in the Thompson orchards at Summit Point so there is no reason to suspect that the variation is due to a difference in location. The records for 1914, 1915, and 1917 show a reasonably uniform relation between number of rust spots per leaf and time of leaf fall regardless of the relative location of the leaves.

Chemical analyses of diseased and healthy leaves gave results somewhat in variance with those published by Reed $(1915$, p. 57), but: further work along this line is to be carried out before final publication of results.

Turning now to the fruit, Plate VII and Plate IX indicate in a general way the fact that a severe rust infection greatly reduces the size of the fruit. In October, 1914, twenty-eight trees were carefuily selected from which to secure data. The apples were sorted as to grades, firsts being about $21 / 2$ inches or over, and seconds about 2 inches to $2 \mathrm{I} / 2$ inches; and as to the number of rusted and non-rusted fruits in each grade. Tables X to XIII give the detailed results according to the treatment. The dropped fruits mentioned in these tables are such as were under trees at picking time.

TABLE X.-Number and Grade of Fruit from Eight Check Trees.

\begin{tabular}{|c|c|c|c|c|c|c|c|}
\hline & \multirow{2}{*}{ Bushels } & \multirow{2}{*}{ Number* } & \multirow[b]{2}{*}{ Percent } & \multicolumn{2}{|c|}{ Rusted } & \multicolumn{2}{|c|}{ Healthy } \\
\hline & & & & Number & Percent & Number & Percent \\
\hline $\begin{array}{l}\text { Picked Fruits: } \\
\text { Firsts } \\
\text { Seconds } \\
\text { Culls }\end{array}$ & $\begin{array}{l}143 / 4 \\
153 / 4 \\
11 \\
\end{array}$ & $\begin{array}{l}2612 \\
3754 \\
4020 \\
\end{array}$ & $\begin{array}{l}25.0 \\
36.0 \\
39.0 \\
\end{array}$ & $\begin{array}{l}1897 \\
2813 \\
3050 \\
\end{array}$ & $\begin{array}{l}72.7 \\
74.7 \\
75.9 \\
\end{array}$ & $\begin{array}{l}715 \\
941 \\
970 \\
\end{array}$ & $\begin{array}{l}27.3 \\
25.3 \\
24.1 \\
\end{array}$ \\
\hline Total Picked & $411 / 2$ & 10386 & & 7760 & 74.9 & 2626 & 25.1 \\
\hline $\begin{array}{l}\text { Dropped Fruits: } \\
\text { Firsts } \\
\text { Seconds } \\
\text { Culls }\end{array}$ & - & $\begin{array}{l}1116 \\
2305 \\
4815 \\
\end{array}$ & $\begin{array}{l}13.7 \\
28.0 \\
58.3 \\
\end{array}$ & $\begin{array}{r}730 \\
1538 \\
3407 \\
\end{array}$ & $\begin{array}{l}65.5 \\
66.8 \\
70.8 \\
\end{array}$ & $\begin{array}{r}386 \\
767 \\
1408 \\
\end{array}$ & $\begin{array}{l}34.5 \\
33.3 \\
29.2 \\
\end{array}$ \\
\hline Total Drops & 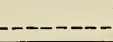 & 8236 & & 5675 & 68.8 & 2561 & 31.2 \\
\hline $\begin{array}{l}\text { Total Firsts } \\
\text { Total Seconds } \\
\text { Total Culls }\end{array}$ & 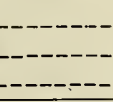 & $\begin{array}{l}3728 \\
6059 \\
8835 \\
\end{array}$ & $\begin{array}{l}20.0 \\
32.5 \\
47.5 \\
\end{array}$ & & & & \\
\hline Grand Total & ----- & 18622 & 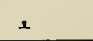 & 13435 & 72.2 & 5187 & 27.8 \\
\hline
\end{tabular}

*Average number of apples per tree, 2328. 
TABLE XI.-Number and Grade of Fruit from Six Trees Sprayed with Lime Sulphur.

\begin{tabular}{|c|c|c|c|c|c|c|c|}
\hline & \multirow{2}{*}{ Bushels } & \multirow{2}{*}{ Number* } & \multirow{2}{*}{ Percent } & \multicolumn{2}{|c|}{ Rusted } & \multicolumn{2}{|c|}{ Healthy } \\
\hline & & & & Number & Percent & Number & Percent \\
\hline $\begin{array}{c}\text { Picked Fruits: } \\
\text { Firsts } \\
\text { Seconds } \\
\text { Culls }\end{array}$ & $\begin{array}{r}35 \\
7 \\
5\end{array}$ & $\begin{array}{l}4904 \\
1652 \\
1944 \\
\end{array}$ & $\begin{array}{l}57.5 \\
19.4 \\
23.2 \\
\end{array}$ & $\begin{array}{r}1699 \\
672 \\
809 \\
\end{array}$ & $\begin{array}{l}34.5 \\
40.7 \\
41.6 \\
\end{array}$ & $\begin{array}{r}3205 \\
980 \\
1135 \\
\end{array}$ & $\begin{array}{l}65.5 \\
59.3 \\
58.4\end{array}$ \\
\hline Total Picked & 47 & 8500 & & 3180 & 37.4 & 5320 & 62.6 \\
\hline $\begin{array}{l}\text { Dropped Fruits: } \\
\text { Firsts } \\
\text { Seconds } \\
\text { Culls }\end{array}$ & $\begin{array}{l}------ \\
------- \\
-\end{array}$ & $\begin{array}{l}1772 \\
1.744 \\
2712 \\
\end{array}$ & $\begin{array}{l}28.5 \\
28.0 \\
43.5\end{array}$ & $\begin{array}{r}632 \\
704 \\
1086 \\
\end{array}$ & $\begin{array}{l}35.7 \\
40.4 \\
40.0\end{array}$ & $\begin{array}{l}1140 \\
1040 \\
1626\end{array}$ & $\begin{array}{l}64.3 \\
59.6 \\
60.0\end{array}$ \\
\hline Total Drops & ------- & 6228 & & 2422 & 38.9 & 3806 & 61.1 \\
\hline $\begin{array}{l}\text { Total Firsts } \\
\text { Total Seconds } \\
\text { Total Culls }\end{array}$ & 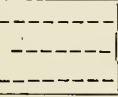 & $\begin{array}{l}6676 \\
3396 \\
4656 \\
\end{array}$ & $\begin{array}{l}45.3 \\
23.1 \\
31.6 \\
\end{array}$ & & & & \\
\hline Grand Total & ------- & 14728 & & 5602 & 38.1 & 9126 & 61.9 \\
\hline
\end{tabular}

*Averiage number of apples per tree, 2455.

TABLE XII.-Number and Grade of Fruit from Eight Trees Sprayed with Bordeaux Mixture.

\begin{tabular}{|c|c|c|c|c|c|c|c|}
\hline & \multirow[b]{2}{*}{ Bushels } & \multirow[b]{2}{*}{ Number* } & \multirow{2}{*}{ Percent } & \multicolumn{2}{|c|}{ Rusted } & \multicolumn{2}{|c|}{ Healthy } \\
\hline & & & & Number & Percent & Number & Percent \\
\hline \multicolumn{8}{|l|}{ Picked Fruits: } \\
\hline Firsts & $391 / 4$ & 6323 & 44.0 & 3044 & 48.1 & 3279 & 51.9 \\
\hline Seconds & $173 / 4$ & 4277 & 29.7 & 2201 & 51.5 & 2076 & 48.5 \\
\hline Culls _-_- & $10 \frac{1}{4}$ & 3805 & 26.3 & 1924 & 50.7 & 18.81 & 49.3 \\
\hline Total Picked & $671 / 4$ & 14405 & & 7169 & 49.6 & 7236 & 50.4 \\
\hline \multicolumn{8}{|l|}{ Dropped Fruits: } \\
\hline Firsts & $\ldots$ & 2112 & 27.9 & 1065 & 50.3 & 1047 & 49.7 \\
\hline Seconds & ------ & 2518 & 33.4 & 1252 & 49.5 & 1266 & 50.5 \\
\hline Culls & ------- & 2921 & 38.7 & 1484 & 50.8 & 1437 & 49.2 \\
\hline Total Drops - & $-\ldots----$ & 7551 & & 3801 & 50.3 & 3750 & 49.7 \\
\hline Total Firsts - & ------- & 8435 & 38.5 & & & & \\
\hline Total Seconds & - & 6795 & 30.9 & & & & \\
\hline Total Culls & ------- & 6726 & 30.6 & . & & & \\
\hline Grand Tota! & - - - - - & 21956 & & 10970 & 50.0 & 10986 & 50.0 \\
\hline
\end{tabular}

*Average number of apples per tree, 2744. 
TABLE XIII.-Number and Grade of Fruit from Six Trees Sprayed with Atomic Sulphur.

\begin{tabular}{|c|c|c|c|c|c|c|c|}
\hline & \multirow{2}{*}{ Bushels } & \multirow{2}{*}{ Number* } & \multirow{2}{*}{ Percent } & \multicolumn{2}{|c|}{ Rusted } & \multicolumn{2}{|c|}{ Healthy } \\
\hline & & & & Number & Percent & Number & Percent \\
\hline $\begin{array}{l}\text { Picked Fruits: } \\
\text { Firsts } \\
\text { Seconds - } \\
\text { Culls }\end{array}$ & $\begin{array}{l}273 / 4 \\
17 \\
10 \\
\end{array}$ & $\begin{array}{l}4401 \\
3652 \\
3657 \\
\end{array}$ & $\begin{array}{l}37.6 \\
31.2 \\
31.2 \\
\end{array}$ & $\begin{array}{l}2114 \\
2049 \\
1952 \\
\end{array}$ & $\begin{array}{l}47.9 \\
56.0 \\
53.3 \\
\end{array}$ & $\begin{array}{l}2287 \\
1603 \\
1705 \\
\end{array}$ & $\begin{array}{l}52.1 \\
44.0 \\
46.7 \\
\end{array}$ \\
\hline Total Picked & $543 / 4$ & 11710 & & 6115 & 52.2 & 5595 & 47.8 \\
\hline $\begin{array}{c}\text { Dropped Fruits: } \\
\text { Firsts } \\
\text { Seconds } \\
\text { Culls }\end{array}$ & | & $\begin{array}{l}1188 \\
1952 \\
2246\end{array}$ & $\begin{array}{l}22.1 \\
36.2 \\
41.7\end{array}$ & $\begin{array}{r}583 \\
1001 \\
1263\end{array}$ & $\begin{array}{l}49.0 \\
51.3 \\
56.3\end{array}$ & $\begin{array}{l}605 \\
951 \\
983\end{array}$ & $\begin{array}{l}51.0 \\
48.7 \\
43.7\end{array}$ \\
\hline $\begin{array}{l}\text { Total Drops } \\
\text { Total Firsts } \\
\text { Total Seconds } \\
\text { Total Culls }\end{array}$ & 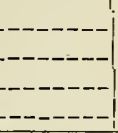 & $\begin{array}{l}5386 \\
5589 \\
5604 \\
5903\end{array}$ & $\begin{array}{l}32.7 \\
32.8 \\
34.5\end{array}$ & 2847 & 52.8 & 2539 & 47.2 \\
\hline Grand Total -- & $-\cdots$ & 17096 & & 8962 & 52.4 & $\$ 134$ & 47.6 \\
\hline
\end{tabular}

*Average number of applés per tree, 2849.

It will be noted that there does not seem to be any greater number of rusted fruits among the drops than among those picked. Evidently the rust-infected fruit does not show any greater tendency to drop than the other fruit during the latter part of the season.

The difference in grade of fruit for the various treatments is quite apparent. It must be remembered, however, when this point is considered that the amount of leaf infection may be a prominent factor in the size of fruit. It is believed that leaf infection is a far more important factor than fruit infection in determining fruit size.

TABLE XIV.-Summary of Rust Effect on Fruit

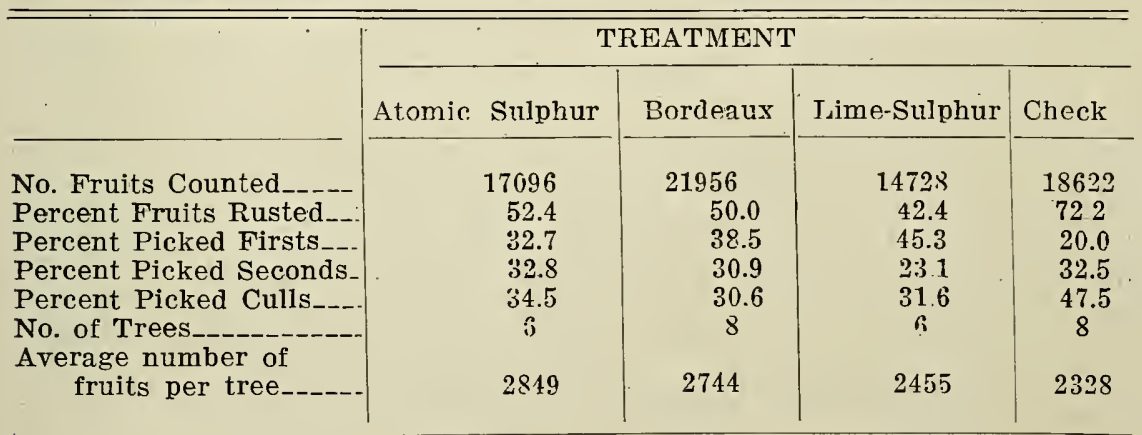




\section{INFECTION AND IMMUNITY OF THE RED CEDAR}

The red cedars often show a very large amount of infection under field conditions, but attemps to convey this disease to them under artificial conditions have not met with success. Weimer (191\%, p. 516 ) reports upon some experiments in which one of the inoculated cedar trees developed a gall, but he acknowledges that the case is not very positive. During the spring of 1915 the author made some inoculations on red cedar trees which had been in the greenhouse for two seasons. Apple trees with infected foliage bearing mature aecia were placed around these cedar trees so that the aeciospores would fall upon them. They were left this way for several days and it rained heavily upon them. The trees were kept under observation for two years but there was no indication of infection. Trees are being grown for further work along this line.

The apparent immunity of certain cedar trees has been frequently commented upon, and various theories have been advanced to account for this condition. In sections where the rust is destructive, it is quite common to see cedar trees with few or no galls, while other trees within a few feet are actually loaded down with them. Close observation of these "immune" cedar trees has led to the belief that such immunity as they may possess is often a direct result of previous heavy infections. Infection by Gymnosporangium juniperi-virginianae apparently takes place only in young growth. If the tree has been severely diseased with this rust for two or more successive seasons its growth is greatly inhibited, and the opportunity for infection would be proportionately reduced. The two-year life cycle of the fungus must be borne in mind when considering this possibility, as an infection taking place in 1913 does not become apparent until 1914.

A noticeable variation in rate and period of growth has also been observed among cedar trees which were some distance from any apple orchard. It may be that growth factors other than those resulting from rust infection have some bearing upon this matter. We do not have any exact records to prove or disprove this theory, but it is a matter worthy of careful attention.

Professor $\mathrm{H}$. H. Whetzel of Cornell University advises that he has observed one case of this apparent immunity in cedars. He has granted permission to use the following statement. *

"During my senior year in Wabash College I made some studies of the Gymnosporangium macropus which occurs very abundantly on cedars and apple trees about Crawfordsville, Indiana. I observed that certain cedar trees were very badly infected, being loaded with galls, large and small, on all their twigs and branches. Other trees standing near were almost or quite free from any infection. A couple of years later I returned to Crawfordsville for a visit and went out again

* This statement is from unpublished records made by Professor Whetzel in connection with some of his early. worl. 
to see the cedar trees from which I had, during my senior year, gotten such large quantities of galls. To my astonishment they were practically free from infection, while others nearby that had borne no galls before were now badly covered with them. What the explanation of this pehnomenon is I do not know. It occurred to me, however, that a serious infection of the trees one season might have rendered them more or less immune for a time. That the infection was on different trees in these two years is certain, as I was very familiar with the different trees with which I had worked."

At the present time a number of marked cedar trees are under observation in a section where the rust is quite bad, but the records cover only two seasons and the evidence is as yet insufficient to warrant conclusions.

The question has sometimes been raised as to how far an infection will be carried from the apple to the cedar. Before discussing this point, it should be stated that there seems to be very little known in regard to the exact manner of cedar tree infection, and the conditions which bring it about. The aeciospores produced on apple foliage and fruit are considerably larger than the sporidia, and presumably weigh more. Under the same conditions we would not expect the aeciospores to be carried as far as the sporidia. It would seem that, if the amount of rust infection in an apple orchard is appreciably reduced by cutting out the cedars for possibly one-fourth mile around it, the amount of infection which would be carried back to the cedars would be reduced in even greater proportion.

There are many reasons why this cannot be expected to work out in actual practice. The four reasons which the author considers to be most important are: The presence of wild crab, seedling, or neglected common apple trees near or among the cedars; the presence of small orchards and what might be termed door-yard apple trees in the close vicinity of the cedars; the probability that the total period during which aeciospores are distributed is very many times greater than the total period of actual sporidia discharge; the great variation in meteorological conditions. There are several important factors such as wind and rain which would be considered under this head, and some other closely related or associated factors, but it hardly seems best to enter into an extended discussion of this matter.

\section{CONTROL OF APPLE RUST}

\section{Use of Sprays}

Ever since spraying for orchard disease became widely adopted there have been occasional attempts to control apple rust by this method. The varying successes of these trials have been mentioned under historical notes.

The incidents directly responsible for our taking up experiments along this line were a very severe outbreak of the rust in the eastern part of the State in 1910, and a case in which a few trees were kept free from it by means of spraying. These controlled trees were part of a row along one side of a large orchard. The owner had some 
atomic sulphur on hand and incidentally applied it to these apple trees to see how effective it would be. It was at once assumed by nearly everyone in that section that this spray would control rust, while others would not. Inquiry failed to locate any other apple trees sprayed on the same date, and a belief was expressed that lime-sulphur or Bordeaux mixture, would control this disease just as effectively as the atomic sulphur, if it were applied at the right time.

During the season of 1911 the rust was not very severe, but no orchards were seen in which spraying had effectively controlled it.

Field Experiments in 1912.-In 1912 experiments were undertaken to determine the possibility and the practicability of controlling apple rust by the use of spray materials. The orchard selected for this work consisted of about 300 York Imperial trees and 300 Ben Davis and other varieties combined. It was situated about two miles northwest of Inwood and was commonly known as the Tabb orchard. The cedar trees had been largely cleared away on two sides of the orchard, but were fairly numerous in pasture land bordering the other sides. A nearly square block consisting of 19 York Imperial and 19 Ben Davis trees was chosen near one end of the orchard. The trees were so located that one might reasonably expect them to receive uniform infection.

The only sprays applied to them during the season were those used in this work. The materials tried were Bordeaux mixture (3 lbs. copper sulphate, 5 lbs. lime, 50 gals. water), commercial limesulphur ( 1 gal. to 40 gals. of water), and atomic sulphur ( 7 lbs. to 50 gals. of water). Each tree was divided into four parts by imaginary vertical planes. A two-cylinder hand pump was used in applying the spray and a pressure of from 50 to 75 lbs. was maintained. One portion of the tree was left unsprayed and each of the other portions was treated with one of the above-mentioned spray materials. A large rubber blanket was spread over as much of the control portion as it would cover, while the tree was being sprayed. A large tag was placed on a branch near the center of each of the four portions after spraying, and no tree was sprayed on more than one date.

\section{PLATE IX}

Fig. 1.-Eighteen typical apples from sprayed portion of York Imperial tree, treated May 6th, at left. Same number of typical fruits from an unsprayed York Imperial tree, at right. Experiments conducted in 1912.

Fig. 2,-Marketable fruit from sprayed portion of York Imperial tree, sprayed May 6th, at left. Total fruit from control portion of same tree, at right. Experiments conducted in 1912. .

Fig. 3.-Eleven-year-old York Imperial apple tree which has not been a severe sufferer from rust infections.

Fig. 4.-Eleven-year-old York Imperial apple tree which has suffered from many severe rust infections. 


\section{PLATE IX}

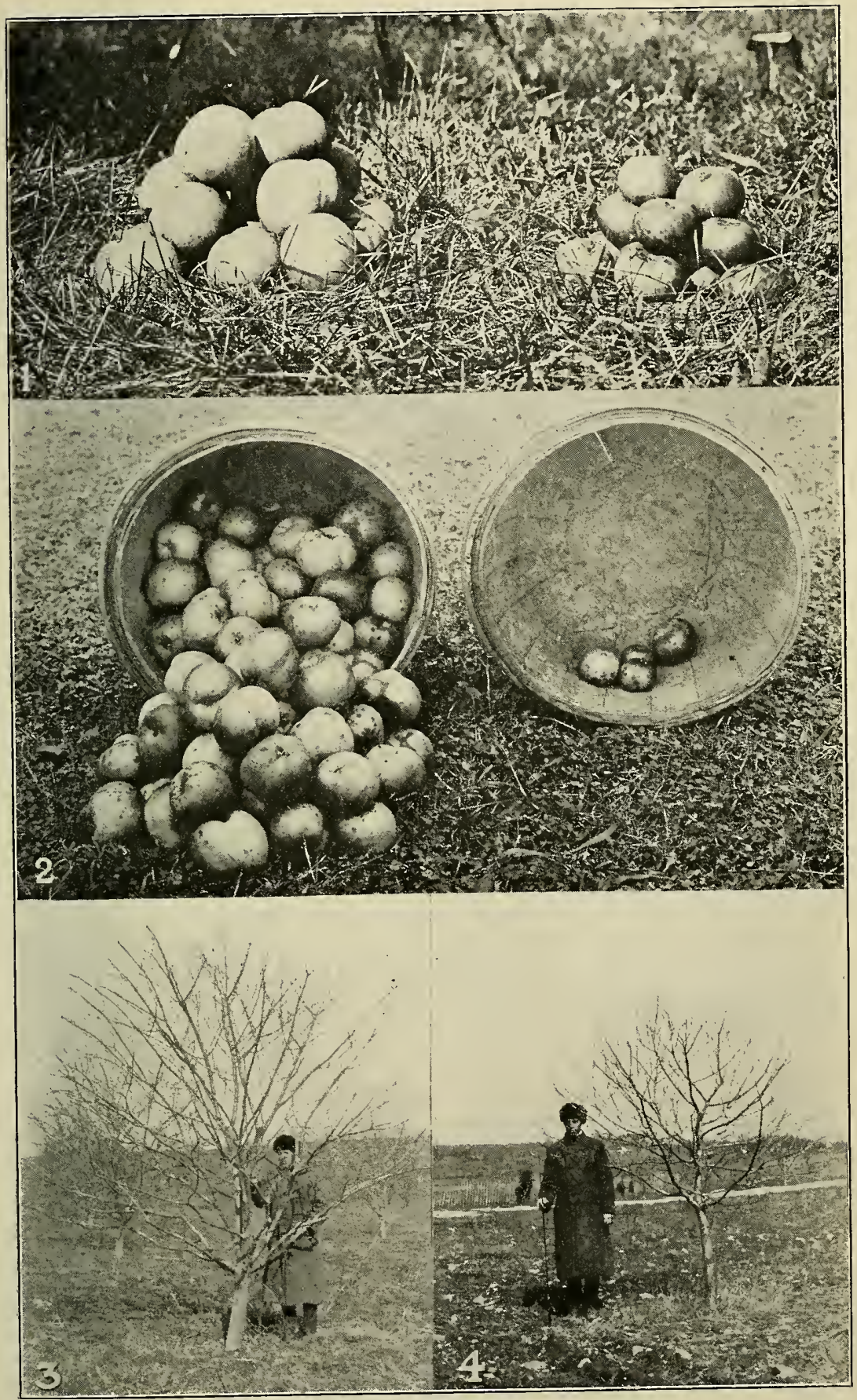


Two trees, one Ben Davis and one York Imperial, were handled in this manner on April, 22nd, 24th, 29th, May 4th, 6th, 8th, 10th. 13th, 15th, 18th, 20th, 22nd, 27th and 29th. Other trees were similarly treated with Bordeaux and lime-sulphur only, on April 18th, 20th, and May 1st; while still others received only lime-sulphur and atomic sulphur on April 26th and May 2nd.

Before the last of May it became evident that the disease was very largely controlled on certain trees. The sprayed portions of the trees treated May 4th and May 6th were especially free from rust. Counts were made early in June to determine the number of diseased and the number of healthy leaves resulting from each treatment. The results secured from trees sprayed April 26th to May 10th are given below :

TABLE XV.-Rust Control on Apple Foliage in 1912 :

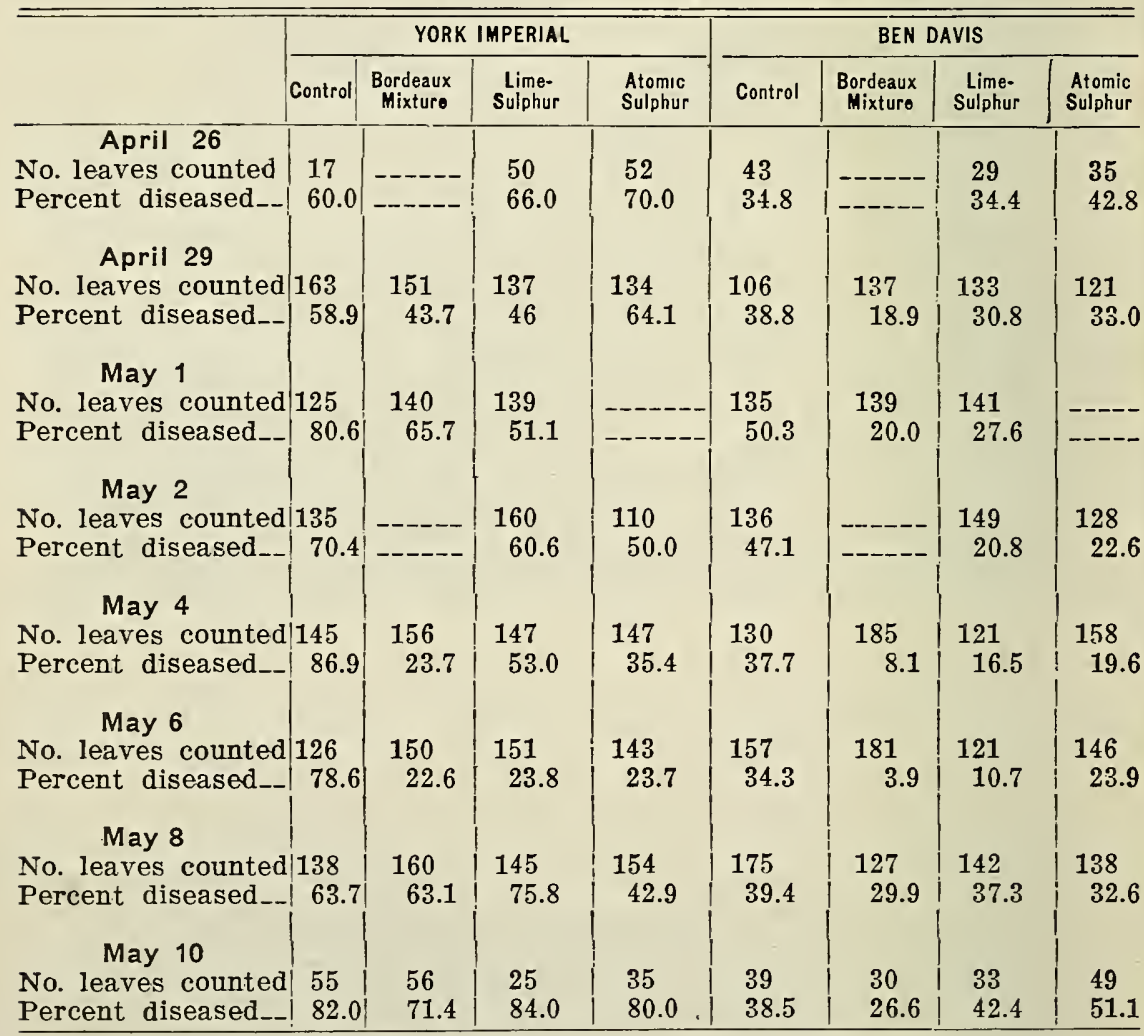

It will be seen from this table that each of the three spray materials applied May 6th was quite effective in controlling the rust. Trees sprayed May 4th were fairly well protected, while those sprayed May 2nd showed no benefit.

Notes as to the number of rust spots per leaf show that they were 
greatly reduced on the sprayed portions of the trees treated May 4th and 6 th, but actual counts of them were not made.

The only marketable York Imperial apples in this orchard were secured from the trees sprayed May 6th. Unfortunately there was little fruit on either the Bordeaux or control portion of this tree.

It was generally stated among orchard men that the York Imperial fruit was not liable to be attacked to a very great extent. Counts of 600 apples taken from several unsprayed York Imperial trees showed an average of 85 percent of the fruit rusted, while there were practically no rusted fruits on the sprayed portions of the trees treated May 6th. A comparatively small number of these fruits were deformed by the disease and this was what had evidently led to the belief that only a small number were infected.

The results secured for this season would indicate that there was a very limited period of time when spraying for control of rust might be successfully undertaken. It should also be noted that the trees were in bloom from about May 2nd to May 5th of this year. Beach (1900) found that spraying in bloom caused a very pronounced decrease in the amount of fruit set. The same thing may have been true of the trees used in these experiments, but they all carried a heavy crop of fruit.

Field Experiments in 1913.-The Frank Mish orchard and the (ieorge M. Bowers orchard at Inwood were selected for this work. The Mish orchard consisted of about 100 York Imperial, 100 Ben Davis, and 200 pear trees, while the Bowers orchard contained about 225 York Imperial trees. The trees in the Mish orchard. were 11 years old while those in the Bowers orchard were 12 to 14 years old. A great many cedars had been cut in the vicinity of these orchards, but enough remained to give a very heavy rust infection under fav. orable conditions.

The spray outfit used was Gould's Monarch hand pump mounted in a light wagon. The materials tested were $32^{\circ} \mathrm{B}$. lime-sulphur (1 to 40 ) ; Bordeaux mixture ( $3 \mathrm{lbs}$. copper sulphate and $5 \mathrm{lbs}$. lime to 50 gals. water); and atomic sulphur, (7 lbs. to 50 gals. water). 
The schedule of spray applications made in these two orchards is given below.

TABLE XVI.--Spraying Dates of Experiments in 1913

\begin{tabular}{|c|c|c|c|c|c|c|c|c|c|c|c|}
\hline \multicolumn{12}{|c|}{ BOWERS } \\
\hline Date & $4-16$ & $4-17$ & $4-18$ & $4-22$ & $4-23$ & $4-24$ & $4-25$ & $4 \_26$ & $4-28$ & $4-29$ & $4-30$ \\
\hline Lime-sulphur - & $\mathrm{x}$ & $\mathrm{x}$ & $\bar{x}$ & $\mathrm{x}$ & $\mathrm{x}$ & $\mathrm{x}$ & $\mathrm{x}$ & $\mathrm{x}$ & $\mathrm{x}$ & $\mathrm{x}$ & $\mathrm{x}$ \\
\hline Atomic sulphur & $\mathrm{x}$ & $\mathrm{x}$ & $\mathrm{x}$ & $\mathrm{x}$ & $\mathrm{x}$ & $\mathrm{x}$ & $\mathrm{x}$ & $\mathrm{x}$ & $\mathrm{x}$ & $\mathrm{x}$ & $x$ \\
\hline Bordeaux -..- & $\mathrm{x}$ & $\mathrm{x}$ & $\mathrm{x}$ & $\mathrm{x}$ & $\mathbf{x}$ & $\mathrm{x}$ & $\mathrm{x}$ & $\mathrm{x}$ & $\mathrm{x}$ & $\mathrm{x}$ & $\mathrm{x}$ \\
\hline Date -- & 5-1 & $5-2$ & $5-3$ & $5-5$ & $5-6$ & $5-8$ & $5-12$ & 5.15 & อ-19 & $5-22$ & $5-26$ \\
\hline Lime-sulphur - & $\mathrm{x}$ & $\bar{x}$ & $\mathrm{x}$ & $\mathrm{x}$ & $\mathrm{x}$ & $\mathrm{x}$ & $\mathrm{x}$ & $\mathrm{x}$ & $\mathrm{x}$ & $\mathbf{x}$ & $\mathrm{x}$ \\
\hline Atomic sulphur & $\mathrm{x}$ & $\mathrm{x}$ & $\mathrm{x}$ & $\mathrm{x}$ & $\mathrm{x}$ & $\mathrm{x}$ & $\mathrm{x}$ & $\mathrm{x}$ & $\mathrm{x}$ & $\mathrm{x}$ & $\mathrm{x}$ \\
\hline Bordeaux _-..- & $\mathrm{x}$ & $\mathrm{x}$ & $\mathbf{x}$ & $\mathrm{x}$ & $\mathrm{x}$ & $\mathrm{x}$ & $\mathrm{x}$ & $\mathrm{x}$ & $x$ & $\mathrm{x}$ & $\mathrm{x}$ \\
\hline
\end{tabular}

\section{MISH ORCHARD}

\begin{tabular}{|c|c|c|c|c|c|c|c|c|c|c|c|}
\hline Date -.-.--- & $4-16$ & $4-17$ & $4-18$ & $4-21$ & $4-22$ & $4-23$ & 4_24 & $4-25$ & $4 \cdot 29$ & $4-30$ & 5-1 \\
\hline Lime-sulphur - & $\mathbf{x}$ & $\mathrm{x}$ & $\mathrm{x}$ & $\mathrm{x}$ & $\mathrm{x}$ & & $\mathrm{x}$ & $\mathrm{x}$ & $\mathrm{x}$ & $\mathrm{x}$ & $\mathrm{x}$ \\
\hline Atomic sulphur & $\mathrm{x}$ & $\mathrm{x}$ & $\mathrm{x}$ & & & $\mathrm{x}$ & $\mathrm{x}$ & $\mathrm{x}$ & & $\mathrm{x}$ & $\mathrm{x}$ \\
\hline Bordeaux & $\mathrm{x}$ & $\mathrm{x}$ & $\mathrm{x}$ & $\mathrm{x}$ & & $\mathrm{x}$ & $\mathrm{x}$ & $\mathrm{x}$ & $\mathrm{x}$ & $\mathrm{x}$ & $\mathrm{x}$ \\
\hline Date & $5-2$ & $5-3$ & $5-5$ & $5-8$ & $5-14$ & & & & & & \\
\hline Lime-sulphur - & $\mathrm{x}$ & $\mathrm{x}$ & $\mathrm{x}$ & $\mathrm{x}$ & $\mathrm{x}$ & & & & & & \\
\hline Atomic sulphur & & $\mathrm{x}$ & $\mathrm{x}$ & $\mathrm{x}$ & $\mathrm{x}$ & & & & & & \\
\hline Bordeaux _...- & & $\mathrm{x}$ & $\mathrm{x}$ & & $\mathrm{x}$ & & & & & & \\
\hline
\end{tabular}

Three trees were included in the test for each material, on every date, in the Bowers orchard; and two trees (one York Imperial and one Ben Davis) for each material on every date in the Mish orchard. There was a fair amount of bloom in the Bowers orchard and scattering bloom on the Yorks in the Mish orchard. The Ben Davis trees in the latter orchard had very fair bloom, but late frosts destroyed practically all of the fruit in both orchards. In Table XVII is given the number and distribution of rust spots on foliage in the Bowers orchards. * The twigs used in making these counts were carefully selected to show average conditions and were taken from different sides of the trees.

* In some cases it will be noted that there are more than 300 rust spots per leaf. The spot counts up to 200 per leaf are believed to be very accurate, but there is probably an error of 5 percent in any count which runs more than 300 spots per leaf. 


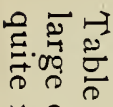

จे $\delta$ 尺

$\because$ के $<\infty$

क जै

ะ

(1)

可的

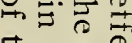

实专?

\& 0 零

$0 \mathrm{~F}$

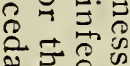

क्षे

율

可吉

कू क

요

-2.

है

壱苛完

范

号艺豆

० 0

후요

( ) F

تंग

矛章喬

(1)

盯㤩

क

政

39

क

乐吕

芛宁す

空.

政.

एक

올 웅

- 공

$+\vec{D}$

击. is

공

จ

$\sum$

क ․․
ชூ・ウー

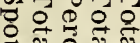
तथ 200

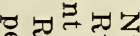
记司范 ॠत्र

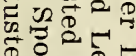
है 政 प1 (8) 焉<smiles>C1CCC2(C1)CCC2</smiles>

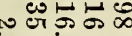
o co

$$
0
$$

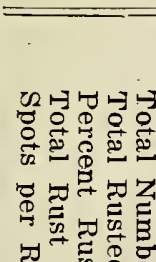

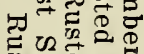
क्व ए। (1) \$

ए 5 क

? 1

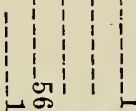

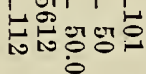

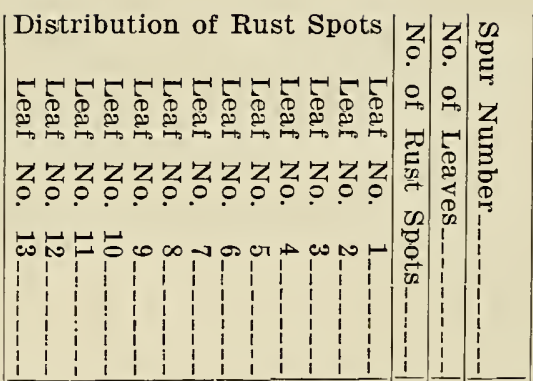

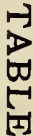

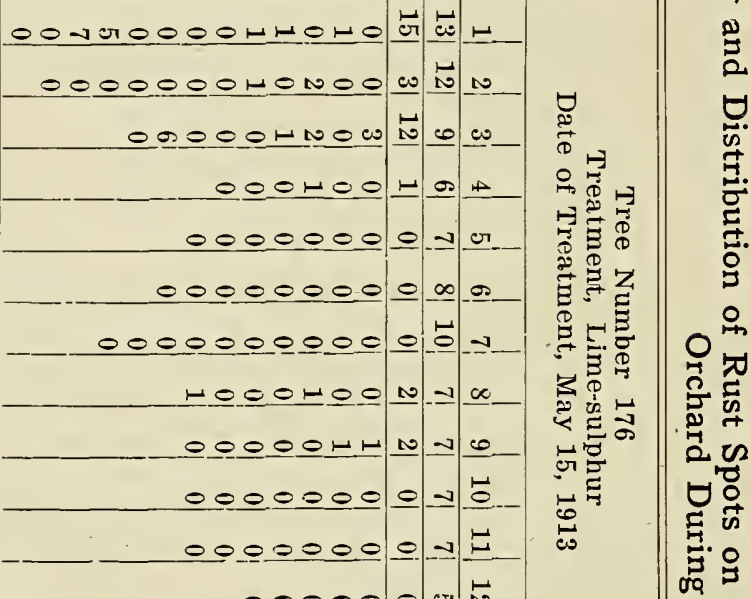

00000 olv

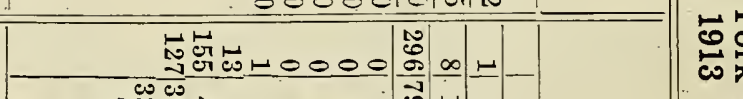

o

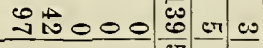

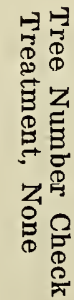

营 
TABLE XVIII.-Rust Control on York Imperial Apple Foliage in Bowers Orchard During 1913

\begin{tabular}{|c|c|c|c|c|c|c|c|c|}
\hline \multirow[b]{2}{*}{ No. } & \multirow[b]{2}{*}{ Date } & \multirow[b]{2}{*}{ Treatment } & \multirow[b]{2}{*}{ Total } & \multicolumn{2}{|c|}{ Rusted } & \multicolumn{2}{|c|}{ Healthy } & \multirow{2}{*}{$\begin{array}{l}\text { Spots Pet } \\
\text { Rusted Leaf }\end{array}$} \\
\hline & & & & Number & Percent & Number & Percent & \\
\hline 128 & $5-3$ & Lime-sulphur _-_-_-_- & 100 & 42 & 42.0 & 58 & 58.0 & 80.5 \\
\hline 132 & $5-3$ & Bordeaux & 75 & 29 & 38.7 & 46 & 61.3 & 32.7 \\
\hline 129 & $5-3$ & Atomic sulphur & 100 & 30 & 30.0 & 70 & 70.0 & 32.3 \\
\hline 161 & $5-8$ & Lime-sulphur _-..--- & 87 & 15 & 17.3 & 72 & 82.7 & 13.1 \\
\hline 163 & $5-8$ & Bordeaux _- & 100 & 30 & 30.0 & 70 & 70.0 & 9.9 \\
\hline 156 & $5-8$ & Atomic sulphur & 98 & 29 & 29.5 & 69 & 70.5 & 16.8 \\
\hline 168 & $5-12$ & Lime-sulphur & 91 & 12 & 13.2 & 79 & 86.8 & 5.3 \\
\hline 167 & $5-12$ & Bordeaux -- & 111 & 28 & 25.2 & 83 & 74.9 & 20.3 \\
\hline 171 & $5-12$ & Atomic sulphur & 109 & 21 & 19.3 & 88 & 80.7 & 9.1 \\
\hline 176 & $5-15$ & Lime-sulphur & 98 & 16 & 16.3 & 82 & 83.7 & 2.2 \\
\hline 181 & $5-15$ & Bordeaux & 116 & 28 & 24.1 & 88 & 75.9 & 2.9 \\
\hline \multirow[t]{3}{*}{178} & $5-15$ & Atomic sulphur & 112 & 24 & 21.4 & 88 & 78.6 & 10.1 \\
\hline & & Check & 101 & 49 & 48.6 & 52 & 51.4 & 127 \\
\hline & & Check & 104 & 48 & 46.2 & 56 & 53.8 & 62 \\
\hline
\end{tabular}

Results for the season 1913 would indicate that one spray application seven days previous to the date of infection may be fairly effective in controlling apple rust on the foliage, while an application twelve days previous is not of much value. The lime-sulphur gave the best control, and Bordeaux mixture next.

The trees were in bloom April 23rd to April 27th, 1913, but the late frosts, previously mentioned, prevented securing any data as to control of rust on fruit, or effect on fruit production, of applications at blooming time.

Field Experiments in 1914.-An orchard in Jefferson County owned by Dr. A. P. Thompson was secured for the work in 1914. This orchard consisted of about 300 York Imperial trees, thirteen years of age, situated along the side and top of a ridge. The trees were in good condition althoing they had suffered severely from.rust during some of the past seasons. A large number of cedars had been cut along one side of the orchard, but there were still many of them on three sides within ten to forty rods of it. The orchard was very free from diseases, aside from apple rust.

The general plan of the experiment may be divided in to two parts: First, to apply each spray material to a few previously unsprayed trees on each day, so far as practicable, in order to determine the effectiveness of one spray application given at any specified time during the spring; second, to learn whether several applications at two-week. one-week, or half-week intervals would be effective in contro!ling the rust.

The orchard was carefully plotted and the trees tagged and numbered consecutively. The spray materials tested were atomic sulphur (7 lbs. to 50 gals.); Bordeaux mixture ( $3 \mathrm{lbs}$. copper sulphate, and 5 ibs. lime to 50 gals.); and $35^{\circ} \mathrm{B}$. home made concentrated lime-sulphur 
(1 to 40$)$. The sprays were applied with a Hardie Junior power outfit, which gave very satisfactory service. A pressure of about 200 pounds was maintained. The tank, hose and rod were washed out before placing in the tank a spray material different from the one last used.

The trees which were to be sprayed on successive dates were divided into six blocks and the trees in each block were clearly indicated by a white letter painted on the trunk of the tree. The spray to be used on any tree was indicated by one, two or three white bands painted around the trunk. Having them marked this way saved considerable time for the man who was spraying and greatly reduced the chance of his making a mistake.

Rainy weather and unavoidable difficulties of one kind or another rendered it impossible to carry out the full spraying schedule on the exact dates planned. The applications on these blocks were made as follows.

\section{TABLE XIX.-Spray Schedule* for Successive Applications in 1914}

\begin{tabular}{|c|c|c|c|c|}
\hline Blocks & $\begin{array}{l}\text { No. } \\
\text { Trees } \\
\text { Bord. }\end{array}$ & $\begin{array}{l}\text { No. } \\
\text { Trees } \\
\text { L. S. }\end{array}$ & $\begin{array}{l}\text { No. } \\
\text { Trees } \\
\text { At. S. }\end{array}$ & Date Sprayed \\
\hline Block A & 3 & 5 & 3 & Apr. 28 , May 1, (L. S.) 2 (Bord. \& At. S.), 4, 7, 11 \\
\hline Block B & 3 & 4 & 3 & Apr. 28 , May 1, (L. S.) 2 (Bord. \& At. S.), 4, 7, 11 \\
\hline Block C & & spray & trees & among sprayed blocks. \\
\hline Block D & 3 & 4 & 3 & May 1, (L. S.), 2 (Bord. \& At. S.) 4, 7, 11, 14 \\
\hline Block E & 3 & 4 & 3 & April 28, May 4,11 \\
\hline Block F & 4 & 4 & 3 & $\begin{array}{l}\text { April 28, May 4, } 11,18,25 \text { (Bord.) } \\
\text { May } 26 \text { (L. S. \& At. S.) }\end{array}$ \\
\hline Block G & 3 & 5 & 3 & April 28 , May $4,11,18$ \\
\hline
\end{tabular}

It so happened that the only serious rust infection of the season of 1914 nccurred May 5th, and all of the blocks had been sprayed on the previous day. As a result there was no more difference between the blocks than would be accounted for by ordinary variation.

The method used in securing data from foliage will be briefly outlined. Three trees in each block were selected for check twig data. One of these trees was sprayed with lime-sulphur, one with Bordeaux, and one with atomic sulphur, but just before applying the spray four exposed twigs on different sides of the tree were tagged and covered with large paper sacks. As soon as the tree had been sprayed these sacks were removed. While they received none of the spray directly, it was found that they did receive an appreciable amount due to the bending down of branches higher up combined with the action of the rain and wind. The amount of protection which such twigs secured raried from forty to seventy-five percent as determined by rust spot counts. These four twigs were covered each time that the tree was sprayed. Four other twigs, comparable in size and exposure, were chosen on the same trees to give data as to the effectiveness of the

* I. S. stands for lime-sulphur, Bord. for Bordeaux, and At. S. for atomic sulphur. Unless otherwise stated. all sprays were applied. The spraying on block A was discontinued after May 11th, by mistake, so that blocks $A$ and $B$ are duplicates. 
spray. On all other sprayed trees four sprayed twigs on four sides of the tree were selected for counting. The twigs on a tree were numbered from 1 to 4 or from 1 to 8 , according to whether or not there were any check twigs on it. On all check trees four twigs were taken, under similar conditions as regards size and exposure. A separate note book page was used for the data from each twig. The leaves 'on a twig were not counted as a whole, but the number from each bud was put down separately. This method was found very accurate and required little more time than the other. The number of spots was actually counted on each rusted leaf for at least the terminal growth of each of the eight twigs on trees which had check twigs, as shown on page 42. Similar spot counts were made on four twigs on each of ten check trees. The first two leaves to unfold, sometimes called the bud leaves, were removed before the first count was made.

As previously stated, these blocks show practically no difference in the effectiveness of the treatments as regards dates of application. It has therefore seemed advisable to omit the lengthy tabulations which would be required to show this, and to present the data from the standpoint of materials only. Table XX gives the number and distribution of rust spots on the foliage of four trees, selected to give as nearly typical and comparable results as seem possible. 


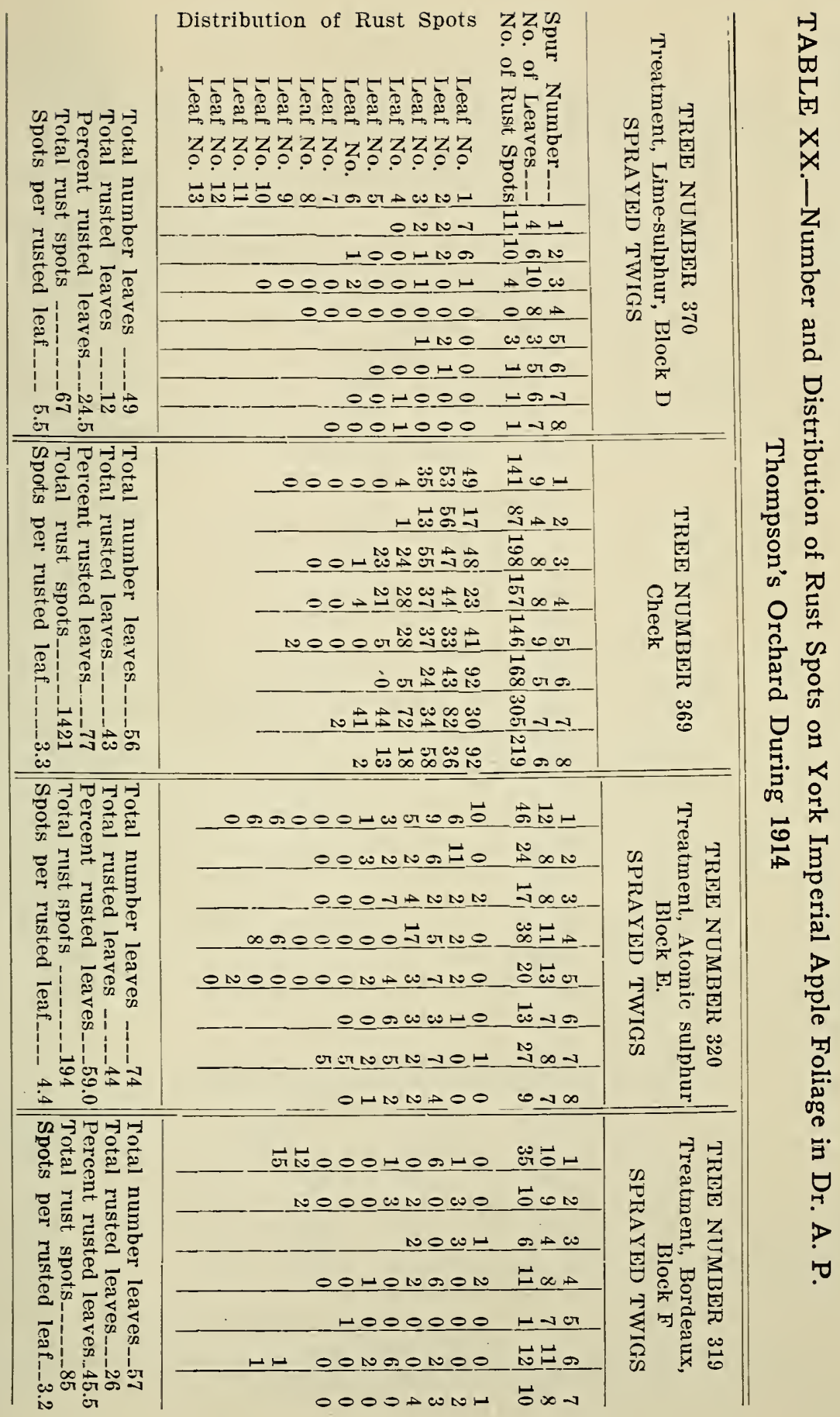


Table XXI shows the total results for each spray material used on the trees which were sprayed on successive dates.

TABLE XXI.-Summary of Rust Control on York Imperial Apple Foliage Sprayed on Successive Dates

\begin{tabular}{|c|c|c|c|c|c|c|}
\hline \multirow{3}{*}{$\begin{array}{l}\text { Number } \\
\text { of } \\
\text { Trees }\end{array}$} & \multirow{3}{*}{ Spray } & \multirow{3}{*}{$\begin{array}{l}\text { Total } \\
\text { Leaves }\end{array}$} & \multicolumn{4}{|c|}{ LEAVES ON SPRAYED TREES } \\
\hline & & & \multicolumn{2}{|c|}{ Rusted } & \multicolumn{2}{|c|}{ Healthy } \\
\hline & & & Number & Porcent & Number & Percent \\
\hline 23 & Lime-sulphur _-_--- & 5493 & 1780 & 32.4 & 3713 & 67.6 \\
\hline 18 & Bordeaux & 4257 & 1401 & 33.0 & 2856 & 67.0 \\
\hline 18 & Atomic sulphur -- & 4543 & 2856 & 62.9 & 1687 & 37.1 \\
\hline
\end{tabular}

\section{CHECK TWIGS}

\begin{tabular}{l|l|r|r|r|r|r}
6 & Lime-sulphur ---- & 1450 & 1121 & 77.4 & 329 & 22.6 \\
6 & Bordeaux ----- & 1384 & 845 & 61.0 & 539 & 39.0 \\
Atomic sulphur -- & 1580 & 1286 & 81.4 & 294 & 18.6 \\
& Unsprayed ----- & 2030 & 1837 & 90.5 & 193 & 9.5 \\
\hline
\end{tabular}

These results, secured from a number of trees and including 1300 to 5000 leaves for each treatment, should give a very fair average. The lime-sulphur is evidently best, with Bordeaux a close second. The general effect of the spray on the check twigs of sprayed trees may also be noted. The average of rusted leaves on check trees was over 90 percent while on the check twigs of sprayed trees it falls as low as 61 percent in the case of Bordeaux mixture.

Although the trees were sprayed in full bloom, there was a heavy crop of apples on nearly every tree in this orchard. Data regarding the control of rust on fruit were therefore secured from a number of trees. The figures in Table XXII include both drops and picked fruit. By the term "drops" is meant, in this case such fruits as were on the ground under the trees at picking time. The detailed data from fruit are given in Tables X to XIII, pages 47 to 49 .

TABLE XXII.-Summary of Rust Control on York Imperial Apple Fruits Sprayed on Successive Dates.

\begin{tabular}{|c|c|c|c|c|c|c|c|}
\hline \multirow{2}{*}{ Treatment } & \multirow{2}{*}{$\begin{array}{l}\text { Total } \\
\text { Fruits }\end{array}$} & \multicolumn{2}{|c|}{ Rusted } & \multicolumn{2}{|c|}{ Healthy } & \multirow{2}{*}{$\begin{array}{c}\text { Number } \\
\text { of } \\
\text { Trees }\end{array}$} & \multirow{2}{*}{$\begin{array}{l}\text { Average No. } \\
\text { Fruits per } \\
\text { Tree }\end{array}$} \\
\hline & & Number & Percent & Number & Percent & & \\
\hline Check -- & 18622 & 13435 & 72.2 & 5187 & 27.8 & 8 & 2328 \\
\hline Lime_sulphur _-_-_- & 14728 & 5602 & 38.1 & 9128 & 61.9 & 6 & 2455 \\
\hline Bordeaux & 21956 & 10970 & 50.0 & 10986 & 50.0 & 8 & 2744 \\
\hline Atomic sulphur ---- & 17096 & 8962 & 52.4 & 8134 & 47.6 & 6 & 2849 \\
\hline
\end{tabular}

Each of the spray materials gave a very pronounced reduction in the percent of rusted fruit, but the lime-sulphur shows up particularly well. 
Turning from the trees which received several successive applications of spray, we will take up those which were sprayed but once. The dates and materials used in this part of the work are indicated below.

TABLE XXIII.-Spray Schedule for Single Application in 1914.

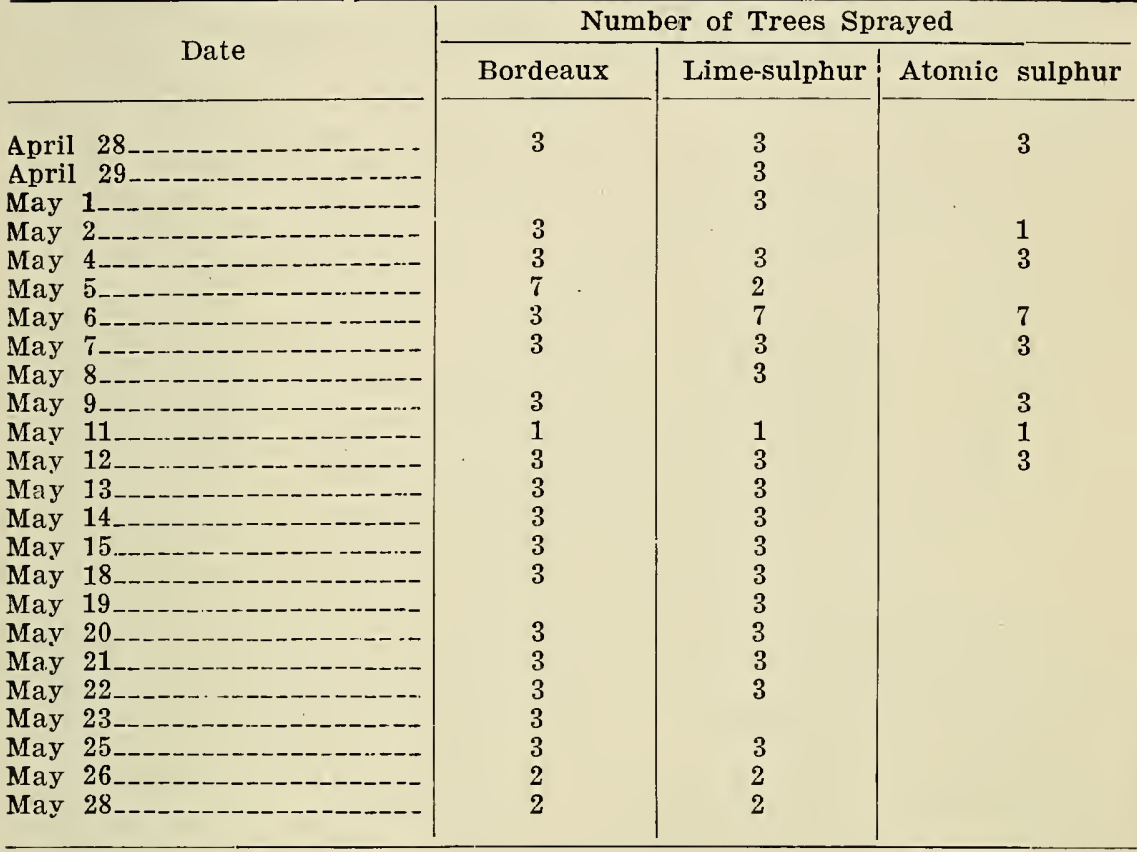


Check twigs were retained on each of the trees used. Since there was no important rust infection after May 5 th counts were made only on trees sprayed previous to that date. Table XXIV shows the effectiveness of the treatments.

\section{TABLE XXIV.-Rust Control on York Imperial Apple Foliage as a} Result of Single Spray Applications in 1914.

\begin{tabular}{|c|c|c|c|c|c|c|c|c|}
\hline \multirow{2}{*}{$\begin{array}{l}\text { Tree } \\
\text { Number }\end{array}$} & \multirow{2}{*}{\multicolumn{2}{|c|}{ Date }} & \multirow{2}{*}{ Spray } & \multirow{2}{*}{$\begin{array}{c}\text { Total } \\
\text { Number }\end{array}$} & \multicolumn{2}{|c|}{ Rusted } & \multicolumn{2}{|c|}{ Healthy } \\
\hline & & & & & Number & Percent & Number & Percent \\
\hline 43 & April & $28 \ldots$ & Lime-sulphur & 215 & 183 & 85.0 & 34 & 15.0 \\
\hline 44 & April & $28 \ldots$ & Atomic suIphur & 306 & 229 & 75.0 & 77 & 25.0 \\
\hline 45 & April & 28 & Bordeaux & 251 & 151 & 60.0 & 100 & 40.0 \\
\hline 242 & April & 29 & Lime-sulphur & 273 & 156 & 27.0 & 118 & 43.0 \\
\hline 204 & May & 1 & Lime-sulphur & 289 & 174 & 60.0 & 115 & 40.0 \\
\hline 191 & May & $1 \ldots$ & Bordeaux _...... & 260 & 144 & 55.4 & 106 & 44.6 \\
\hline 219 & May & $1_{--n}$ & Atomic sulphur & 232 & 166 & 71.0 & 66 & 29.0 \\
\hline 249 & May & $2 \ldots$ & Lime-sulphur _._- & 312 & 145 & 46.5 & 167 & 53.5 \\
\hline 221 & May & $2 \ldots$ & Bordeaux & 222 & 93 & 42.0 & 132 & 58.0 \\
\hline 4 & May & $4---$ & Lime-sulphur & 334 & 88 & 26.5 & 246 & 73.5 \\
\hline 5 & May & $4 \ldots-$ & Atomic sulphur & 279 & 132 & 48.0 & 147 & 52.0 \\
\hline 7 & May & 4 & Bordeaux & 348 & 63 & 18.0 & 285 & 82.0 \\
\hline
\end{tabular}

LEAVES ON CHECK TWIGS

\begin{tabular}{|c|c|c|c|c|c|c|c|}
\hline 42 & -- & --_- & 186 & 161 & 87.0 & 25 & 13.0 \\
\hline 43 & April 28_- & Lime-sulphur & 201 & 147 & 73.0 & 54 & 27.0 \\
\hline 44 & April 28_ & Atomic sulphur & 227 & 174 & 76.5 & 53 & 23.5 \\
\hline 45 & April 28_- & Bordeaux _-_- & 325 & 215 & 66.0 & 110 & 34.0 \\
\hline 242 & April 29-- & Lime-sulphur _-_-- & 230 & 185 & 81.0 & 45 & 19.0 \\
\hline 204 & May 1--- & Lime-sulphur & 230 & 202 & 88.0 & 28 & 12.0 \\
\hline 191 & May $1 \ldots$ & Bordeaux & 261 & 220 & 84.1 & 41 & 15.8 \\
\hline 219 & May 1 & Atomic sulphur -- & 194 & 163 & 84.0 & 31 & 16.0 \\
\hline 249 & Mav 2.... & Lime-sulphur & 147 & 127 & 86.4 & 20 & 13.6 \\
\hline 221 & May 2_-_ & Bordeaux _-_-_- & 168 & 126 & 75.0 & 42 & 25.0 \\
\hline 4 & May 4_... & Lime_sulphur & 247 & 176 & 72.0 & 71 & 28.0 \\
\hline 5 & May 4_.-- & Atomic sulphur -- & 247 & 1.51 & 62.0 & 96 & 38.0 \\
\hline 7 & May 4_--- & Bordeaux --_---- & 293 & 147 & 50.0 & 146 & 50.0 \\
\hline 223 & --- & Check _- & 162 & 153 & 95.0 & 9 & 5.0 \\
\hline
\end{tabular}

The results of these trials would indicate that a spray application one week previous to infection is ineffective for control of rust, while the same material applied one day previously is very effective and applied three days previously is fairly effective.

The data for 1912 indicated practically the same thing. The data of infection in 1914 were almost the same as in 1912 and the date of blooming for the trees in 1912 was about May 2-5, while in 1914 it was May 1-5. The blossom buds were just showing good color on April 27th, and the so-called cluster bud spray was being applied at that time in a nearby orchard. A large portion of the central blossom buds opened on May 1st. May 4th, practically every blossom had opened and during that day a very few petals fell from the earlier blossoms. It was impossible to spray until about noon, on May 5th, and applications made at that time showed no control of rust. The only time when spray could have been effectively applied for the 
control of apple rust in 1914 was when the trees were in bloom. A glance at the last column in Table XXII will show that there vere more fruits matured upon the trees sprayed May 4th, in full bloom, than upon the check trees. Many young fruits may have been killed, but the trees still needed thinning. From our experiments thus far, we would not hesitate to recommend that York Imperial apple trees, showing a good amount of bloom, should receive one spray application of lime-sulphur without arsenical poison while they are in bloom, provided the apple rust is prevalent and destructive in that section.

So far as has been learned, there is no evidence that the lime-sulphur spray would be injurious to bees visiting the blossoms after this spray has been applied.

In 1915 a spray schedule was arranged upon the basis of the results secured for the three previous seasons, and an attempt was made to control the rust by following out this schedule in a small commercial orchard. Seven applications were called for within 32 days, and beginning when the blossom buds showed pink. Commercial lime-sulphur 1-40 was used for the spray. The first four applications were made on schedule time and there had been no infection of importance. On the day when the fifth application was due there was a heavy and almost continuous rainfall. 'This rain resulted in a severe rust infection, and it undoubtedly washed much of the previously applied spray from the foliage. The trees were spraved as soon as conditions would permit on the next day, but the infection for that period had already taken place and there was no further infection that season. The sprayed portion of this orchard did not show quite so much rust as the unsprayed trees, but the amount of protection was far from sufficient to warrant the expense and trouble.

It is entirely clear from these spraying experiments that apple rust can be readily controlled by the common spray mixtures such as lime sulphur, paste sulphur, and Bordeaux mixture.

It is equally evident that such spraying for rust control is absoiutely impracticable for the commercial orchardist.

In some very rare cases where the number of apple trees was limit ed to a small home orchard and the cedar trees were numbered by thousanids it might be worth while to try to control the rust by spraying. In any such case it should be borne in mind that the infection period lasts only about one month in the spring, and that the leaves must be kept well coated during that period.

\section{DESTRUCTION OF RED CEDARS}

The destruction of the red cedar has been quite universally recommended as the best and most practical method of controlling apple rust. Although this method of control is so generally accepted we find only one reference to a careful experiment for determining its efficiency. Jones $(1893$, p. 83 ) as quoted on page 6 , secured some definite evidence regarding this point.

Reed (1914, p. 23) gives reports from orchard men as to the effectiveness of cutting out cedars, but details as to distances, area, etc., are not mentioned. 
The value of the cedars must be taken into consideration when dealing with a problem of this kind. The red cedar, Juniperus virginianae is of very little commercial importance in West Virginia. It occurs quite commonly throughout the state and is abundant in some of the principal apple growing sections. Most of the growth is of no value because of its inferior, bushy development. There are many fields which should be cleared of these scrub cedars because of the increased pasture value which would result (Plate X, Fig. 3). The larger trees find use as fence posts and telephone poles but comparatively few are valuable for sawed lumber, and it is said that only red, heart wood is good for fence posts. The sentimental value which may be attached to cedars is often a factor of great importance, and is far more difficult to deal with than a mere commercial value. There are very few places where the value of an orchard would not greatly outweigh the value of all the red cedar trees to be found within such range that they would be likely to produce serious rust infection.

During the winter of $1913-14$ the West Virginia State Crop Pest Commission began active work in the destruction of red cedars in Berkeley County, W. Va. From the records of the man in charge of this work it was found that 1,114 acres were rendered cedar free at a total cost of $\$ 532.68$, or an average cost of less than 48 cents per acre. The acreage here represented included thickets, woodlots pastures, meadows bordered with cedars, etc., and may be considered as fairly typical for that part of the state.

The work of the State Crop Pest Commission was soon transferred to the newly created office of Commissioner of Agriculture and the work on red cedar destruction received a temporary setback. Cooperative arrangements for continuing the work were finally made between the Experiment Station, the Commissioner of Agriculture, and some of the orchard men of Berkeley County. In connection with this work a circle was surveyed around each of three commercial York Imperial apple orchards. The circle around one orchard was surveyed so as to have a radius of one mile from the outer portions of the orchard, the circle around another orchard was surveyed so as to have a radius of one and one-half miles from the outer portions of the orchard, and the circle around the third orchard was surveyed so as to have a radius of two miles from the outer portions of the orchard. The largest circle had an actual diameter of about five miles and contained about four thousand acres. The three circles were located on reasonably similar ground along the same valley,

\section{PLATE X}

Fig. 1-Cedar trees scattered in with other growth at Falling Waters, W. Va. Fig. 2.-A row of roadside cedars and an apple tree in bloom. Note apple tree is situated in row along with cedars.

Fig 3.-Cedar trees in pasture field near Inwood, W. Va. 


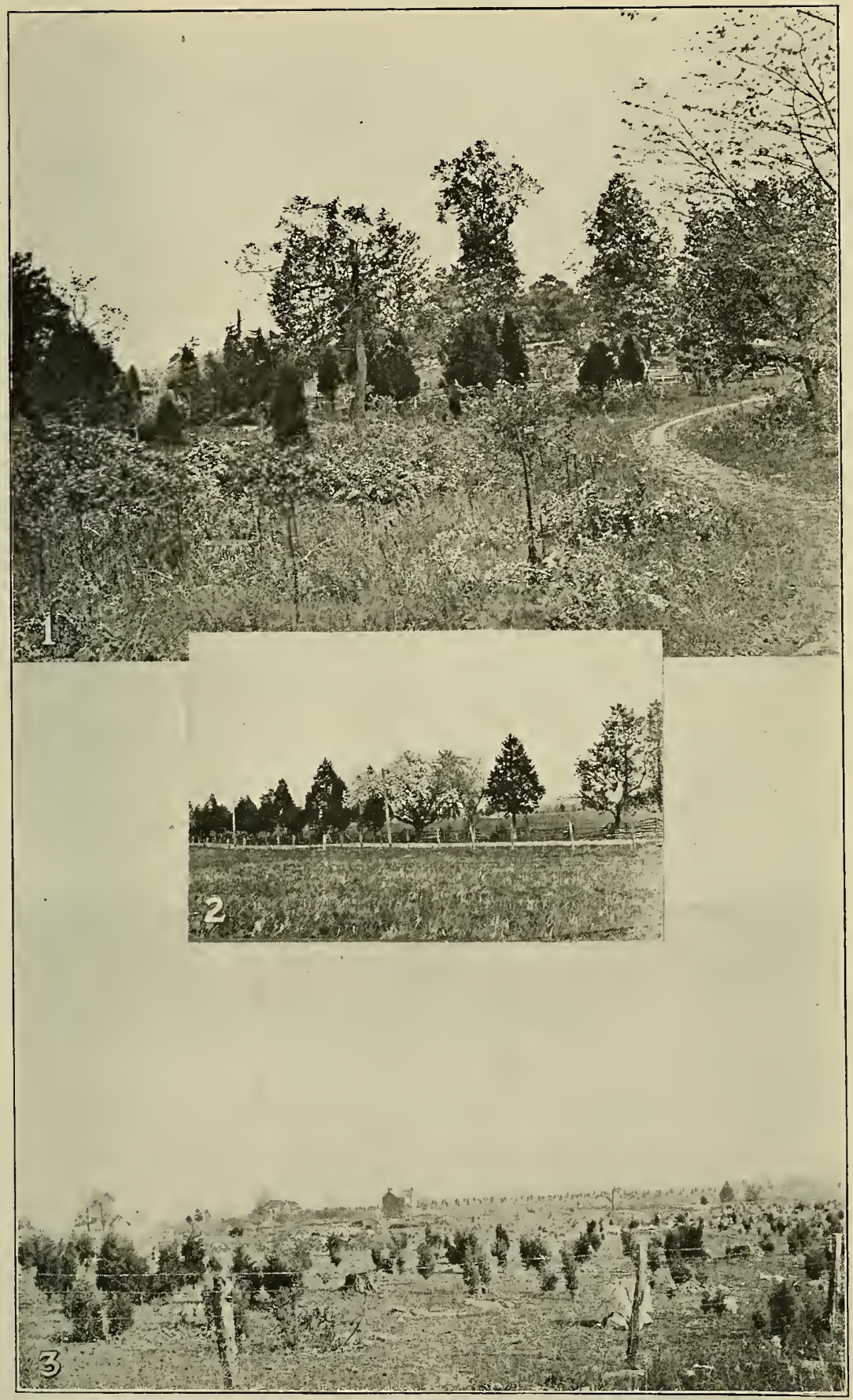


and with a space of one to five miles between them. Our plan was to destroy all red cedar trees in these three circles, but not to destroy them around or between the circles. This object has not been entirely attained as yet, but the two large circles are cleared back to the circumference nearly all the way around. We were unable to convince the orchard men that it would be a worth while experiment to stop at the margin of the smaller circle and most of the cedars have been cut for a very considerable distance around it. In connection with this work we have data on meteorological conditions, and infection periods. Some extremely valuable results have been secured already, and it is clearly evident that under the conditions found in eastern West Virginia, the cedar free radius around apple orchards of susceptible varieties should be two miles if reasonably satisfactory results are to be secured. In 1917 the amount of rust on the foliage of trees around which the circles were laid out was fifty to seventyfive percent less than in other large commercial orchards where cedars had been cleared away for possibly a third or half mile around. The Thompson orchard was taken as a type of a badly infected orchard and the amount of rust there may be noted from Table VII.

\section{Destruction or Prevention of Rust Galls}

Cedar trees around a house are sometimes highly valued and the owners often desire to remove the rust galls instead of destroying the trees. It is possible that this practice may be effectively carried out in some cases, but it is a most tedious operation, and must be repeated year after year if good results are to be secured. We have records of several cases where it has been tried and abandoned. A man will usually revise his ideas as to the value of a cedar tree by the time he has spent ten to fifteen hours picking rust galls from it.

The spraying of cedars as reported by Heald $(1909$, p. 112) would doubtless be far more practical for the treatment of cases of this kind. This department has not conducted any experiments in the spraying of cedar trees.

\section{PLATE XI}

Fig. 1.-Meteorological instruments, showing equipment and exposure.

Fig. 2.-Instrument shelter for hygrothermograph. 
PLATE XI

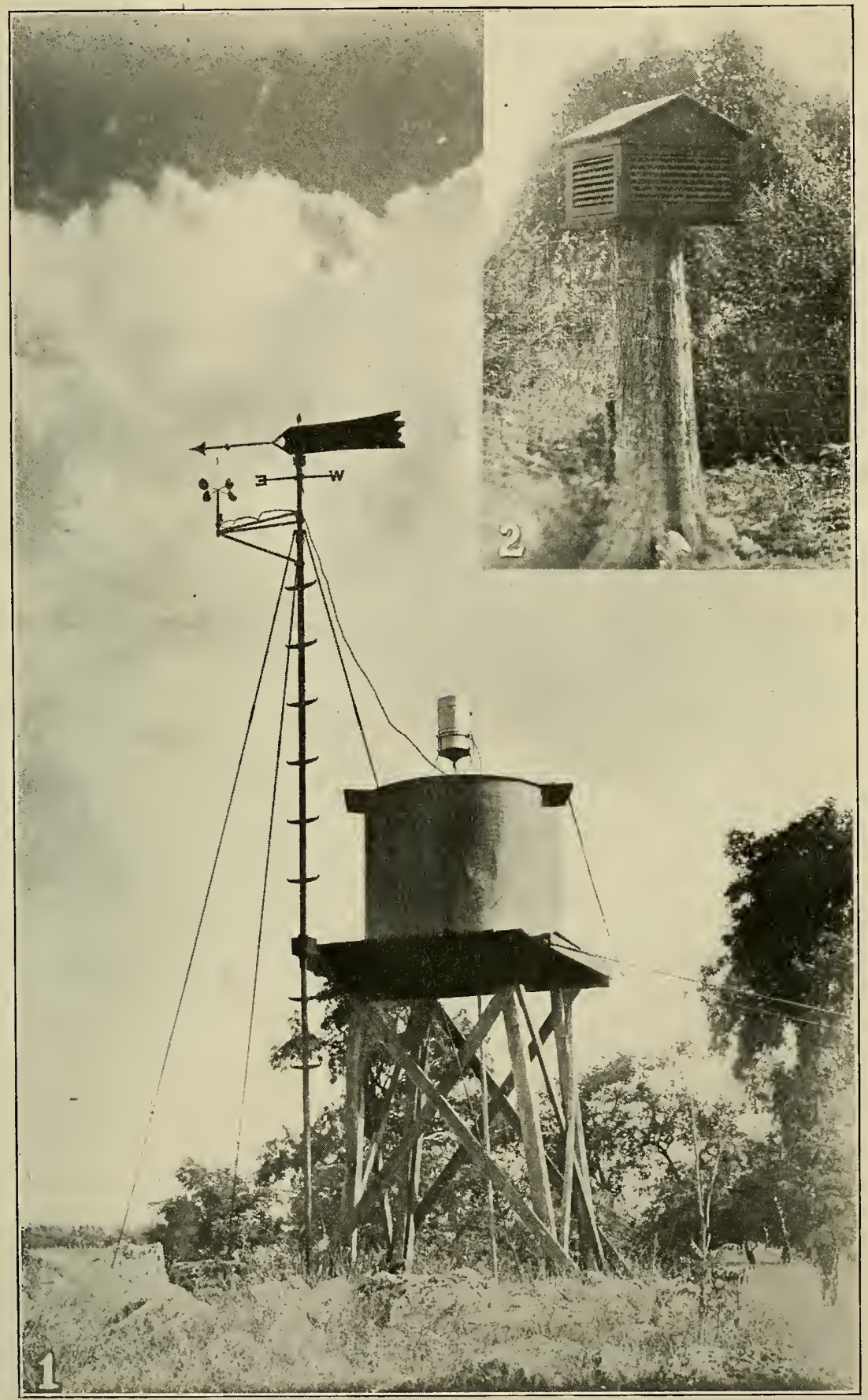




\section{LITERATURE CITED}

Austin, C. F. (1901) Orchard Notes-Ala. Agr. Exp. Sta. Bul. 11\%, p. 296.

Bartholomew, E. (1912) Apple Rust Controlled by Spraying-Phytopathology, V. II, No. 6, p. 253.

Beach, S. A. and Bailey, L. H. (1901) Spraying in Bloom-N. Y. (Geneva) Agr. Exp. Sta. Bul. 196.

Coons, G. H. (1912) Some Investigations of the Cedar Rust Fungus--Neb. Agr. Exp. Sta. Rpt. 25, p. 217.

Farlow, W. G. (1880) The Gymnosporangium of Cedar Apples of the United States-Anniv. Mem. Boston Society Nat'1 History 28.

Fulton, H. R. (1913) Infection of Apple Leaves by Cedar Rust-N. C. Agr. Exp. Sta. Rpt. 35, (1912) p. 62.

Galloway, B. T. (1889) Report of the Section of Vegetable Pathology -Rpt. U. S. Dept. Agr. p. 413.

Giddings, N. J. (1911) Apple Rust-Farm and Orchard, Vol. I. No. 12 , p. 3.

Giddings, N. J. and Neal, D. C. (1912) Control of Apple Rust by Spraying-Phytopathology, V. II, No. 6, p. 258.

Giddings, N. J. and Berg, A. (1915) Apple Rust-W. Va. Agr. Exp. Sta. Bul. 154.

Halstead, B. D. (1889) Apple Rusts-Rpt. U. S. Dept. Agr. (1888) p. $3 \% 0$.

Heald, F. D. (1907) Gymnosporangium Macropus-Science N. Ser. V. XXVI, No. 659, p. 219.

(1908) Notes on Gymnosporangium macropus-Science N. Ser. V. XXVII, No. 68 , p. 210

(1909) The Life History of the Cedar Rust Fungus-Neb. Agr. Exp. Sta. Rpt. 22, p. 105.

Hein, W. H. (1908) Cedar Rust-Insect Pest and Plant Disease Bureau of Neb., Cir. 1.

Jones, L. R. (1891) Report of the Botanist-Vt. Agr. Exp. Sta. Rpt. 4 (1890) p. 139.

(1892) Report of the Botanist-Vt. Agr. Exp. Sta. Rpt. 5 (1891) p. 133.

(1893) Report of the Botanist-Vt. Agr. Exp. Sta. Rpt. 6 (1892) p. 83.

Jones, L. R., and Bartholomew, E. T. (1915) Apple Rust and Jts Control in Wisconsin-Wis. Agr. Exp. Sta. Bul. $25 \%$. 
McCarthy, Gerald (1893) The Diseases and Insects Affecting Fruit Trees and Plants, With Remedies for Their Destruction-N. C. Agr. Exp. Sta. Bul. 92, p. 86.

Pammel, L. H. (1891) Treatment of Fungus Diseases-Ia. Agr. Exp. Sta. Bul. 13, p. 41.

(1905) The Cedar Apple Fungi and Apple Rust in Iowa--Ia. Agr. Exp. Sta. Bul. 84.

Reed, H. S., Cooley, J. S. and Rogers, J. T. (1912) Foliage Diseases of the Apple-Rpt. on Spraying Experiments in 1910 and 1911, Va. Agr. Exp. Sta. Bul. 195, p. 6.

Reed, H. S. and Cooley, J. S. (1913) The Effect of Gymnosporangium upon the Transpiration of Apple trees. The Fiffect of the Cedar Rust Upon the Assimilation of Carbon Dioxide by Apple Leaves -Va. Agr. Exp. Sta. Rpt. (1912) p. 82-94. Also abstracted in Science N. Ser. V. XXXV, p. 155.

Reed, H. S., Cooley, J. S., and Crabill, C. H. (1914) Experiments on Control of Cedar Rust of Apples-Va. Agr. Exp. Sta. Bul. 203.

Reed, H. S. and Crabill, C. H. (1915) Respiration in Apple L,eaves Infected with Gymnosporangium-Science N. Ser. V. XI.I. p. 180. (1915) The Cedar Rust Disease of Apples Caused by Gymno.sporangium Juniperi-Virginianae. Schw.-Va. Agr. Exp. Sta. Tech. Bul. 9 .

Stewart, F. C. (1910) Notes on New York Plant Diseases-N. Y. (Geneva) Agr. Exp. Sta. Bul. 328, p. 316.

Stewart, F. C. and Carver, C. W. (1896) Inoculation Experiments with Gymnosporangium macropus-N. Y. (Geneva) Agr. Exp. Sta. Rpt. 14 (1895) pp. 535 to 544.

Thaxter, R. (1889) Notes on Culțres of Gymnosporangium Made in 1887 and 1888-Bot. Gaz. 14, p. 163.

(1891) The Connecticut Species of Gymnosporangium-Conn. Agr. Exp. Sta. Bul. 10\%.

Weimer, James LeRoy (1917) Three Cedar Rust Fungi: Their Life Histories and the Diseases They Produce-N. Y. (Cornell) Agr. Exp. Sta. Bul. 390.

Whetzel, H. H. (1901) Notes on Apple Rusts-N. Proc. Ind. Acad. Sci., p. 255. 






